RADOVI

Zavoda za znanstveni rad HAZU Varaždin

VLADIMIR HUZJAN

Zavod HAZU u Varaždinu

vhuzjan@hazu.hr
UDK 355.1:718:94(497.523Varaždin)“1914/1918“

Izvorni znanstveni članak

Original Scientific Paper

Primljeno: 10. 05. 2018.

Prihvaćeno: 13. 06. 2018.

\title{
VOJNE ŽRTVE VELIKOG RATA I PORAĆA POKOPANE NA VARAŽDINSKOM GROBLJU (1914.-1919.)
}

U ovome radu autor donosi popis vojnika - žrtava Velikog rata i poraća koji su pokopani na varaždinskom groblju. Rad se objavljuje u povodu 100. obljetnice završetka Proog sojetskog rata.

\section{UVOD}

U studenome 2018. u Republici Hrvatskoj, Europskoj uniji i drugim državama čiji su vojnici sudjelovali u bitkama Velikog rata, prigodno će se obilježiti 100. obljetnica završetka Prvog svjetskog rata. Do svoga završetka to je bio sukob u kojem je stradalo najviše vojnika, a čije se žrtve mjere u milijunima. Dio njih pokopan je u Varaždinu.

Što se tiče žrtava Velikog rata na varaždinskom području, autor se do sada više puta bavio tom temom. U koautorskom radu: "O korisnicima osobnih invalidnina sudionika Prvoga svjetskog rata - popis Narodnog odbora kotara Varaždin" obrađeni su podaci iz Matične knjige korisnika ličnih invalidnina sudionika Proog svjetskog rata gdje su zabilježeni osobni podaci 374 vojna invalida sa šireg varaždinskog područja. ${ }^{1}$ Kako je ta matična knjiga nastala krajem 1947., do tog trenutka dio vojnih invalida Velikog rata već je umro, tako da ne znamo njihov ukupan broj. Analizom podataka utvrđeno je da je najveći broj invalida rođen na području Varaždinske županije, u vojsci su većinom imali status borca/ redova, a najviše ih je bilo mobilizirano prve ratne godine. Čak 92 posto su bili Hrvati, 77 posto oženjeni, a 49 posto je imalo djecu. Unatoč invalidskom statu-

1 Vladimir HUZJAN, Jasmin MEDVED, "O korisnicima osobnih invalidnina sudionika Prvoga svjetskog rata - popis narodnog odbora kotara Varaždin", Varaždin i sjeverozapadna Hrvatska u Velikom ratu 1914.-1918., zbornik radova sa znanstvenog skupa s međunarodnim sudjelovanjem održanim u Varaždinu 3. i 4. srpnja 2014., Hrvatska akademija znanosti i umjetnosti, Zavod za znanstveni rad u Varaždinu, Posebna izdanja - knjiga 25, Zagreb-Varaždin, 2014., str. 189-246. 
su, 59 posto ih je radilo u svom domaćinstvu, a 68 posto je imalo nekretninu u vlasništvu. ${ }^{2}$

U drugom koautorskom radu: "O korisnicima obiteljskih invalidnina sudionika Prvog svjetskog rata - popis Narodnog odbora kotara Varaždin" obrađeni su podaci iz Matične knjige korisnika porodičnih invalidnina sudionika Prvog svjetskog rata nastale krajem 1947. ili početkom 1948. godine. ${ }^{3}$ Ovdje su obrađeni osobni podaci o 498 obitelji sa šireg varaždinskog područja koje su nakon Drugog svjetskog rata primale naknadu za poginule ili nestale muške članove na bojištima Velikog rata. Analizom podataka utvrđeno je da je najveći broj primatelja obiteljske invalidnine bio s područja Varaždinske županije, 95 posto bile su žene, 85 posto primatelja Hrvatske nacionalnosti, a 49 posto je imalo djecu. Iako za 43 posto vojnika nije navedeno gdje su smrtno stradali ili nestali, 21 posto stradao je na ruskom ratištu, 13 posto na srpskom, osam posto na talijanskom, a kod kuće sedam posto. ${ }^{4}$

Na kraju, u trećem radu pod nazivom: "O ranjenicima i zarobljenicima u Varaždinu 1914. i 1915. te invalidima i ratnom groblju nakon Velikog rata" govori se o stranim vojnicima - žrtvama Velikog rata pokopanim na varaždinskom groblju. ${ }^{5}$ Podaci su preuzeti iz Imenika stranih ratnika pokopanih na gradskom groblju u Varaždinu koji je nastao krajem 1920-ih. Tada je Grad Varaždin planirao urediti Ratnički odio na groblju, a popis stranih pokopanih vojnika sastavljen je zbog obavijesti veleposlanstvima da se uključe u uređenje, ali su svi odbili. Prema Imeniku radi se o više od 200 pokopanih vojnika iz Rusije, Italije, Njemačke, Poljske, Madžarske, Austrije, a na tom su popisu stranaca i vojnici iz Istre koja je tada bila pod talijanskom okupacijom.

\section{VOJNICI POKOPANI NA GROBLJU}

Ovim, četvrtim, radom zaokružuje se cjelina - u njemu su obrađeni podaci o preostalim pokopanim vojnicima - žrtvama Velikog rata na varaždinskom groblju koji su rođeni na području današnje Hrvatske, Slovenije, Srbije i Bosne i Herce-

$2 \quad$ Isto, str. 198.-199.

3 Vladimir HUZJAN, Jasmin MEDVED, "O korisnicima obiteljskih invalidnina sudionika Prvog svjetskog rata - popis Narodnog odbora kotara Varaždin", Radovi Zavoda za znanstveni rad Varaždin, Hrvatska akademija znanosti i umjetnosti, Zavod za znanstveni rad u Varaždinu, ZagrebVaraždin, 2014., br. 25, str. 479.-551.

4 Isto, $489 .-490$.

5 Vladimir HUZJAN, "O ranjenicima i zarobljenicima u Varaždinu 1914. i 1915. te invalidima i ratnom groblju nakon Velikog rata", Varaždin i sjeverozapadna Hrvatska u Velikom ratu 1914.-1918., zbornik radova sa znanstvenog skupa s međunarodnim sudjelovanjem održanim u Varaždinu 3. i 4. srpnja 2014., Hrvatska akademija znanosti i umjetnosti, Zavod za znanstveni rad u Varaždinu, Posebna izdanja - knjiga 25, Zagreb-Varaždin, 2014., str. 161.-188. 
govine. Podaci su prepisani i obrađeni iz sljedećeg izvornog arhivskog gradiva: 345. Knjiga mrtvaca, općeniti grobovi, III. (1879) 1903-1918.; 345. Knjiga mrtvacah obiteljskih grobnica 1902.-1919. (dvije knjige) te Knjiga mrtvacah občenitih grobova 1902. koje se nalaze u Državnom arhivu u Varaždinu. Na kraju članka je poglavlje Prilozi 2 u kojem je prijepis osobnih podataka stradalih vojnika u promatranom razdoblju.

Rezultati dobivenih istraživanja predstavljeni su u grafikonima (vidi Prilog 1). Prvi prikazuje da je u ratnim godinama najviše vojnika smrtno stradalo/ pokopano 1918., zadnje godine rata, a najmanje 1914., prve godine rata. U analizi su i tri vojnika pokopana 1919. godine. Radi se o konjičkom stražmeštru Ladislavu Matuzlencu(?) iz Brdovca kraj Zaprešića, zatim računarskom podčasniku Vjekoslavu Svačku iz Varaždina te pješaku Narodne vojske S. H. S. Franji Moltesu iz Podturena. ${ }^{6}$ Vojnici su najviše umirali od tuberkuloze i upale pluća, a nešto manje od prostrijelnih rana ili tifusa. Nekoliko vojnika počinilo je samoubojstvo: ulan 12. ulanske pukovnije Gjuro Ban, zatim Mirko Martan iz Podruta se ustrijelio iz puške, a dvojica su se objesili: topnik Vilim Gorički iz Klanjca i Gjuro Bogdan iz 10. domobranske husarske pukovnije. ${ }^{7}$

Iako u većini slučajeva nije navedeno gdje je vojnik umro (jer su upisivači vjerojatno smatrali da se podrazumijeva u Varaždinu op. a.), najviše vojnika umrlo je u Varaždinu tj. u jednom od odjela Pričuvne bolnice u Optujskoj ulici. S druge strane, svega jedan pokopani vojnik je poginuo na (srpskom) bojištu - poručnik 10. husarske pukovnije Ivan Lehpamer iz Varaždina. U zagrebačkoj bolnici Crvenog križa umro je pričuvni poručnik Stanislav Magdić iz Varaždina, sin gradonačelnika Pere Magdića. ${ }^{8}$ Glede bračnog stanja umrlih vojnika, najveći broj je oženjenih (49 posto), dok je neoženjenih nešto manje (43 posto). Za njih sedam posto nije navedeno bračno stanje, a udovca su ukupno tri: Štefan Mikac iz Nove Vesi, Eugen pl. Pust iz Varaždina i Tomo Pallaš iz Peteranca. ${ }^{9}$ Prema godinama života, najviše umrlih vojnika je od 20 do 29 godina starosti (39 posto) te od 30 do 39 godina starosti (29 posto). Mlađi od 20 godina starosti čine osam posto umrlih vojnika. Najmlađe žrtve Velikog rata su dvojica 17-godišnjih srpskih zarobljenika: Blagoje Stojanović iz Beograda i Alexander Sajić, obojica umrla od tuberkuloze. ${ }^{10}$ S druge strane, najstariji pokopani vojnik je spomenuti 85-godišnji Tomo Pallaš iz

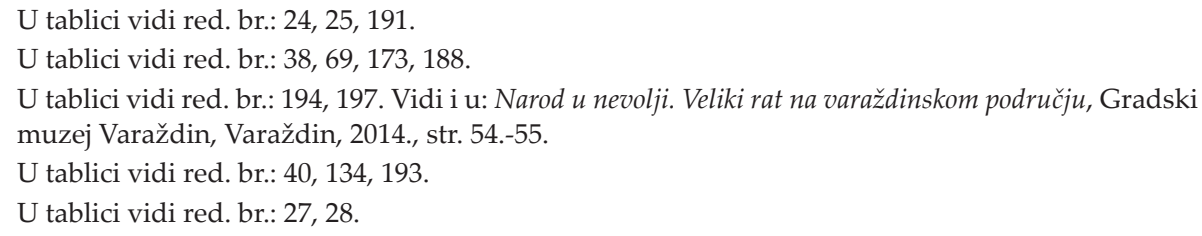


Peteranca kraj Koprivnice. ${ }^{11} \mathrm{Na}$ kraju, prema podacima iz posljednjeg grafikona, 83 posto umrlih vojnika pokopanih na varaždinskom groblju rođeno je na tlu današnje Hrvatske, dok ostali zajedno (njih 11 posto) potječe s područja današnje Austrije, Slovenije, Srbije te Bosne i Hercegovine. ${ }^{12}$

Treba naglasiti da su osobni podaci vojnika strane nacionalnosti pokopanih na varaždinskom groblju već objavljeni na osnovu prijepisa iz Imenika stranih ratnika pokopanih na gradskom groblju u Varaždinu. ${ }^{13}$ No, taj popis, iako s greškama, nije cjelovit jer provjerom arhivskog gradiva uočena su još 25 vojnika čija imena nisu ranije spomenuta, a sada se po prvi puta navode (vidi Prilog 3).

\section{ZAKLJUČAK}

U ovom radu se po prvi puta objavljuje popis stradalih vojnika - žrtava $V e$ likog rata pokopanih na varaždinskom groblju, a rođenih na području današnje Hrvatske, Austrije, Slovenije, Bosne i Hercegovine i Srbije. Upravo je stota godišnjica završetka Prvog svjetskog rata poslužila kao prigoda da se oda počast žrtvama toga rata, a doprinos historiografiji je u prijepisu i obradi osobnih podataka žrtava. Prema tim podacima, najviše je vojnika stradalo/ pokopano zadnje godine rata, a najviše su umirali od tuberkuloze i upale pluća. Osim par

11 U tablici vidi red. br.: 40.

12 Rodna mjesta umrlih vojnika (Republika Hrvatska): Baneš(?) - 1; Baničevac - 1; Bednja - 1; Benkovac - 1; Božinci - 1; Brdovec - 1; Brinj - 1; Brod na Savi/ Slavonski Brod; Bržinci -1; Budinščina -1 ; Budrovac - 1; Bušin - 1; Cigrovec - 1; Cista - 1; Čakovec - 1; Čavoglave - 1; Daruvar - 2; Djelekovac - 2; Dragljena - 1; Draškovec - 1; Dubovec - 1; Dubovica - 1; Dubrava - 1; Duga Resa - 1; Garačić(?) - 1; Gardinovec - 1; Gjurgjevac - 1; Glina - 1; Gorica kod (?) -1; Gospić - 1; Gotalovec - 1; Gračac - 4; Grubišno Polje - 1; Gundinci -1; Hrastovec - 1; Ivanec - 4; Jablanac - 1; Jakopovec - 1; Jalkovec - 2; Jalžabet - 2; Jaska -1; Ježovec - 1; Kastelnovo - 1; Klanjec - 2; Klenovnik - 1; Kneginec - 2; Knin - 1; Kontarna(?) - 1; Kozarac - 1; Kraljevac - 1; Križevci -1; Kruševo - 2; Kutjevo - 1; Leštakovec - 2; Livno - 1; Lobor - 1; Ludbreg - 1; Lukoran - 1; Lužan - 1; Mali Bukovec - 1; Martinci -1; Mičelinac - 1; Miholjska - 1; Mihovac - 1; Nedelišće - 1; Nedeljanec - 1; Novaves - 1; Novi Marof - 3; Obrovac - 1; Ogulin - 2; Osijek - 2; Otočac - 2; Pazarište - 1; Pazin - 1; Pertinja 1; Peteranec - 2; Petrinja - 1; Plešivica - 1; Podbablje - 1; Podrute - 1; Podturen - 2; Popovača - 1; Pregrada - 1; Preseka - 1; Prijedor - 1; Pučišće - 1; Pušča - 1; Selnik - 2; Slatina - 1; Slunja - 1; Smiljan - 1; Split - 2; Sračinec - 1; Staroselo - 1; Sv. Juraj - 1; Svinjičko - 1; Šenkovci - 1; Šibenik 1; Tordinci - 1; Trgovišće - 2; Trnovec - 1; Varaždinske Toplice - 1; Varaždin - 18; Vedropolje - 1; Veleškovec - 1; Velika Gorica - 1; Velika Pisanica - 2; Veliki Novaki - 1; Vinicabereg - 1; Vinkovci - 1; Virje - 1; Visoko - 1; Višnjik - 1; Vratno - 1; Vrhovec - 1; Vukovar - 1; Zabok - 1; Zagreb - 1; Zamlaka - 1; Zlatar - 4; Žarovnica - 1; Županja - 1. Iz Republike Austrije: Beč - 1. Iz Republike Slovenije: Jesovec (pri Smarju) - 1; Velika Ves - 1; Kamnik - 1; Studenci - 1; Kameni Most - 1. Iz Republike Srbije: Kragujevac - 3; Beograd - 1; Ruma - 1; Smederevo - 1; Valjevo - 1; Banovo Brdo - 1; Kraljevo - 1; Nepoznato/ nečitko mjesto - 2. Iz Republike Bosne i Hercegovine: Priseka - 2; Livno - 1; Petrovac - 1; Visoko - 1; Dubica - 1; Prijedor - 1. Nije navedeno: 14. Ukupno: 214.

13 Vidi: Vladimir HUZJAN, "O ranjenicima i zaroblje,nicima u Varaždinu 1914. i 1915. te invalidima i ratnom groblju nakon Velikog rata", str. 161.-188. 
izuzetaka, gotovo svi su umrli u Varaždinu u Pričuvnoj bolnici u Optujskoj ulici. Prema godinama starosti, najveći broj vojnika umro je u desetljeću između 20 i 29 godina starosti, ipak najmlađe žrtve su dva 17-godišnja zarobljena srpska vojnika. U ukupnom broju stradalih vojnika 83 posto rođeno je na tlu današnje Republike Hrvatske.

\section{SAŽETAK}

\section{VOJNE ŽRTVE VELIKOG RATA I PORAĆA POKOPANE NA VARAŽDINSKOM GROBLJU (1914.-1919.)}

U ovom radu se po prvi puta objavljuje popis stradalih vojnika - žrtava Velikog rata pokopanih na varaždinskom groblju, a rođenih na području današnje Hrvatske, Austrije, Slovenije, Bosne i Hercegovine i Srbije. Upravo je stota godišnjica završetka Prvog svjetskog rata poslužila kao prigoda da se oda počast žrtvama toga rata, a doprinos historiografiji je u prijepisu i obradi osobnih podataka žrtava. Prema tim podacima, najviše je vojnika stradalo/ pokopano zadnje godine rata, a najviše su umirali od tuberkuloze i upale pluća. Osim par izuzetaka, gotovo svi su umrli u Varaždinu u Pričuvnoj bolnici u Optujskoj ulici. Prema godinama starosti, najveći broj vojnika umro je u desetljeću između 20 i 29 godina starosti, ipak najmlađe žrtve su dva 17-godišnja zarobljena srpska vojnika. U ukupnom broju stradalih vojnika 83 posto rođeno je na tlu današnje Republike Hrvatske.

Ključne riječi: Prvi svjetski rat; Varaždin; vojnik; žrtva; groblje. 


\section{ZUSAMMENFASSUNG ${ }^{14}$ \\ AUF DEM VARAŽDINER FRIEDHOF BEGRABENE KRIEGSOPFER DES GROSSEN KRIEGES UND DER NACHKRIEGSZEIT (1914-1919)}

In der vorliegenden Arbeit wird zum ersten Mal die Liste der verstorbenen Soldaten - der Opfer des Großen Krieges, die auf dem Varaždiner Friedhof begraben und im Gebiet des heutigen Kroatien, Österreich, Slowenien, Bosnien und Herzegowina und Serbien geboren sind, veröffentlicht. Gerade das hundertjährige Jubiläum vom Ende des Ersten Weltkrieges diente als Anlass, um den Opfern dieses Krieges die Ehre zu erweisen, währenddessen der Beitrag zur Historiographie in der Abschrift und Bearbeitung der persönlichen Angaben der Opfer liegt. Laut diesen Angaben sind die meisten Soldaten in den letzten Kriegsjahren gestorben/begraben worden, wobei sie am häufigsten an Tuberkulose und Lungenentzündung starben. Außer ein paar Ausnahmen sind fast alle in Varaždin im Ersatzkrankenhaus in Optujska Straße gestorben. Nach dem Alter ist die Großzahl der Soldaten im Jahrzehnt zwischen 20 und 29 Jahren gestorben, aber die jüngsten Opfer waren zwei gefangene 17-jährige Soldaten aus Serbien. Von der Gesamtzahl der verstorbenen Soldaten sind 83 Prozent im Gebiet der heutigen Republik Kroatien geboren.

Schlüsselwörter: Erster Weltkrieg; Varaždin; Soldat; Opfer; Friedhof.

$\overline{14}$ Sažetak prevela Sanja Županić, prof. 


\section{Prilog 1. Analitički grafikoni}
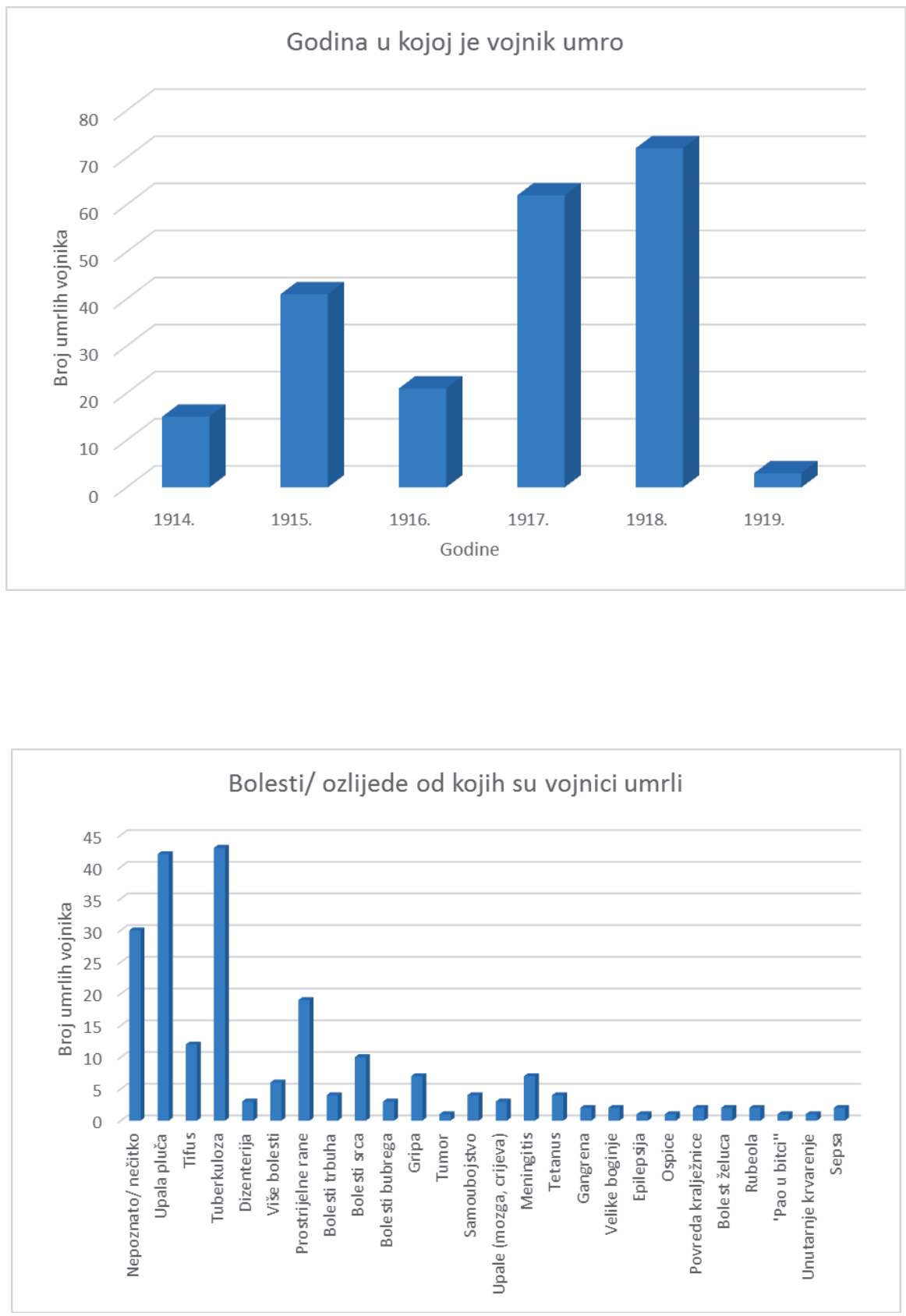

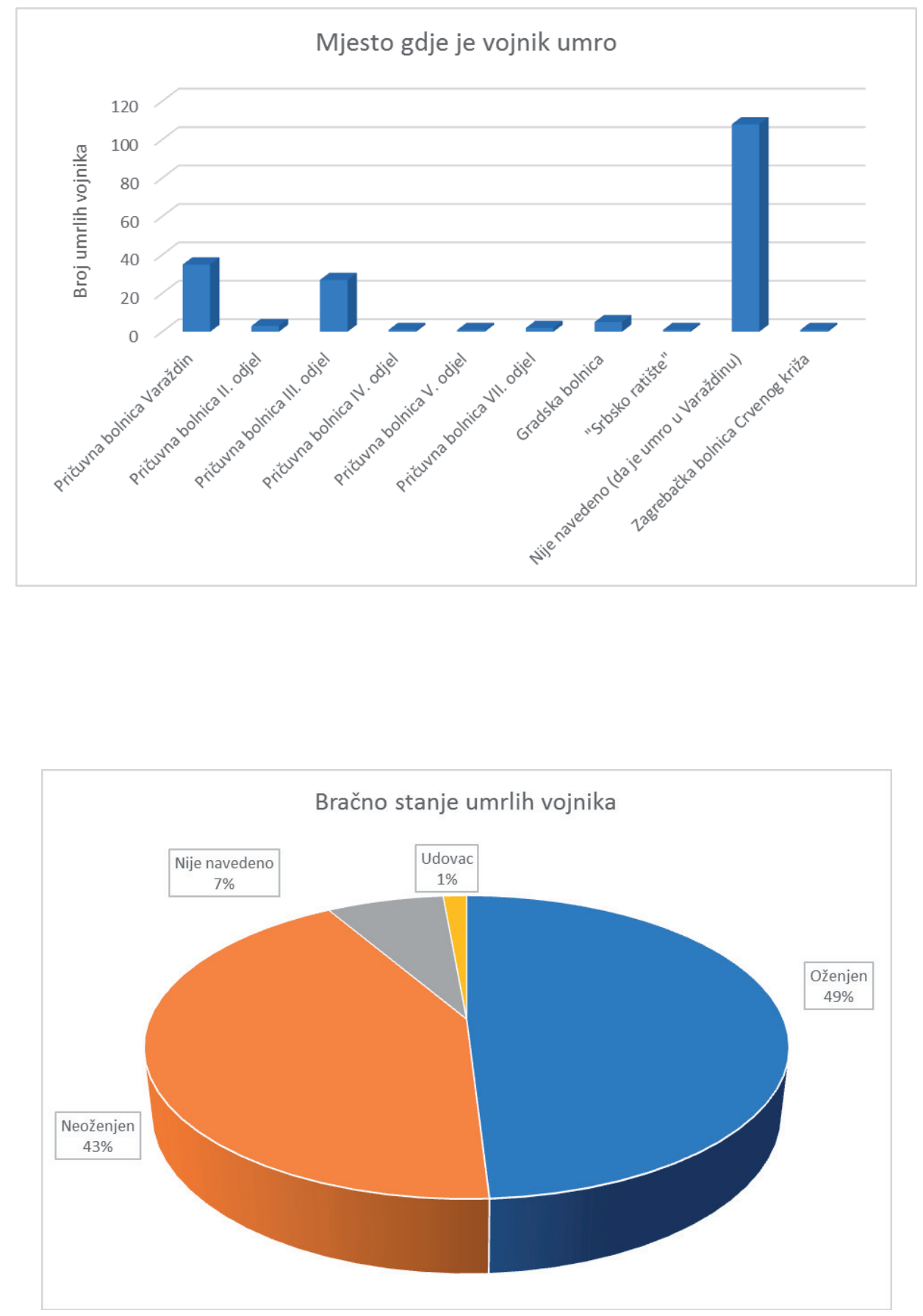

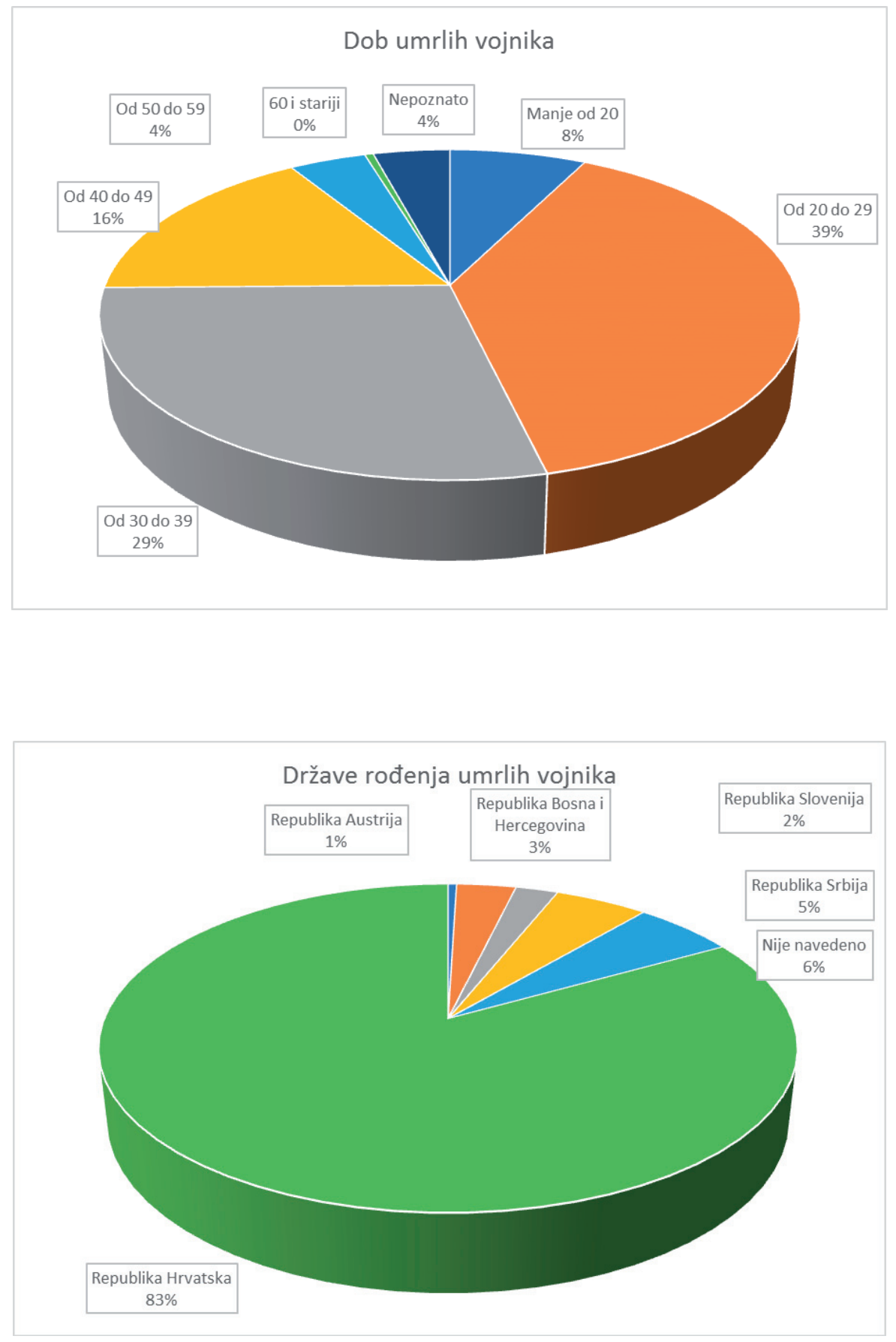
Prilog 2. Vojne žrtve Velikog rata i poraća pokopane na Varaždinskom groblju (1914.-1919.)

Napomene oko tablica: službenici su često nerazumljivo upisivali uzrok smrti stoga se na određenom broju ne može utvrditi. Datum ukopa je ujednačen.

345. Knjiga mrtvaca, općeniti grobovi, III (1879) 1903-1918.

\begin{tabular}{|c|c|c|c|c|c|c|c|c|}
\hline $\begin{array}{l}\text { Red. } \\
\text { broj }\end{array}$ & $\begin{array}{c}\text { Broj } \\
\text { groba }\end{array}$ & $\begin{array}{l}\text { Ime, prezime } \\
\text { i zanimanje }\end{array}$ & $\begin{array}{l}\text { doba, stališ } \\
\text { i rodno } \\
\text { mjesto }\end{array}$ & $\begin{array}{c}\text { mjesto } \\
\text { obitavanja }\end{array}$ & $\begin{array}{c}\text { posljednja } \\
\text { bolest } \\
\text { s koje je umro }\end{array}$ & $\begin{array}{c}\text { dan i } \\
\text { godina } \\
\text { kada je } \\
\text { sahranjen }\end{array}$ & Opazka & $\begin{array}{l}\text { Napomena } \\
\text { autora }\end{array}$ \\
\hline 1 & 1052 & $\begin{array}{c}\text { Prelog Ivo } \\
\text { vozni topnik c. } \\
\text { k. } 39 \\
\text { poljskotopnički } \\
\text { regiment }\end{array}$ & $\begin{array}{c}24 \text { god. } \\
\text { neoženjen } \\
\text { Voloder kod } \\
\text { Popovače }\end{array}$ & $\begin{array}{l}\text { Varaždin } \\
\text { četna } \\
\text { bolnica }\end{array}$ & Upala mozga & $\begin{array}{l}11.2 . \\
1914 .\end{array}$ & $\begin{array}{c}7 \text { tabla } \\
1 \text { red } \\
\text { br. } 1052\end{array}$ & \\
\hline 2 & 385 & $\begin{array}{c}\text { Aleksa Rajačić } \\
\text { vojnik }\end{array}$ & $\begin{array}{l}21 \text { god. } \\
\text { neož. } \\
\text { Brinj }\end{array}$ & $?$ & Upala pluća & $\begin{array}{l}24.10 . \\
1918 .\end{array}$ & $\begin{array}{c}13 \text { tabla } \\
7 \text { red } \\
\text { br. } 385\end{array}$ & $\begin{array}{l}\text { Počasni } \\
\text { grob }\end{array}$ \\
\hline 3 & 382 & $\begin{array}{c}\text { Franjo } \\
\text { Ključarić } \\
\text { vojnik }\end{array}$ & $\begin{array}{c}29 \text { god. } \\
\text { oženjen } \\
\text { Mali } \\
\text { Bukovec }\end{array}$ & $\begin{array}{c}\text { Mali } \\
\text { bukovec } \\
\text { Ludbreg } \\
\text { Varaždin }\end{array}$ & $\begin{array}{l}\text { Španojska } \\
\text { gripa }\end{array}$ & $\begin{array}{l}22.10 . \\
1918 .\end{array}$ & $\begin{array}{c}13 \text { tabla } \\
7 \text { red } \\
\text { br. } 382\end{array}$ & $\begin{array}{c}\text { Počasni } \\
\text { grob. } \\
\text { Isti upis u: } \\
\text { 345. Knjiga } \\
\text { mrtvacah } \\
\text { obiteljskih } \\
\text { grobnica } \\
\text { 1902.-1919. } \\
\text { red. br. } 465\end{array}$ \\
\hline 4 & 394 & $\begin{array}{l}\text { Štefan Bubek } \\
\text { topnik }\end{array}$ & $\begin{array}{l}43 \text { god. } \\
\text { oženjen } \\
\text { Varaždin }\end{array}$ & Majerje & Dizenterija & $\begin{array}{l}6.11 . \\
1918 .\end{array}$ & $\begin{array}{c}13 \text { tabla } \\
7 \text { red } \\
\text { br. } 394\end{array}$ & $\begin{array}{l}\text { Počasni } \\
\text { grob }\end{array}$ \\
\hline 5 & 403 & $\begin{array}{l}\text { Gjuro Horvat } \\
\text { tapetar. } \\
\text { pomoćnik } \\
\text { vojnik }\end{array}$ & $\begin{array}{c}26 \text { god. } \\
\text { neož } \\
\text { Varaždin }\end{array}$ & Varaždin & Upala (pluća) & $\begin{array}{l}22.11 . \\
1918 .\end{array}$ & $\begin{array}{c}13 \text { tabla } \\
7 \text { red } \\
\text { br. } 403\end{array}$ & Vojnik \\
\hline 6 & 348 & $\begin{array}{c}\text { Dragutin } \\
\text { Altman } \\
\text { kolarski } \\
\text { pomoćnik }\end{array}$ & $\begin{array}{l}26 \text { god. } \\
\text { neož } \\
\text { Bučica }\end{array}$ & Ivanec & Upala (pluća) & $\begin{array}{l}17.11 . \\
1918 .\end{array}$ & $\begin{array}{c}13 \text { tabla } \\
7 \text { red } \\
\text { br. } 398\end{array}$ & $\begin{array}{c}\text { Počasni } \\
\text { grob }\end{array}$ \\
\hline
\end{tabular}




\begin{tabular}{|c|c|c|c|c|c|c|c|c|}
\hline $\begin{array}{l}\text { Red. } \\
\text { broj }\end{array}$ & \begin{tabular}{|c|} 
Broj \\
groba
\end{tabular} & $\begin{array}{l}\text { Ime, prezime } \\
\text { i zanimanje }\end{array}$ & $\begin{array}{l}\text { doba, stališ } \\
\text { i rodno } \\
\text { mjesto }\end{array}$ & $\begin{array}{c}\text { mjesto } \\
\text { obitavanja }\end{array}$ & $\begin{array}{c}\text { posljednja } \\
\text { bolest } \\
\text { s koje je umro }\end{array}$ & $\begin{array}{c}\text { dan i } \\
\text { godina } \\
\text { kada je } \\
\text { sahranjen }\end{array}$ & Opazka & $\begin{array}{c}\text { Napomena } \\
\text { autora }\end{array}$ \\
\hline 7 & 399 & $\begin{array}{c}\text { Mato Obad } \\
\text { topnik }\end{array}$ & $\begin{array}{l}37 \text { god. } \\
\text { oženjen } \\
\text { Lužan }\end{array}$ & Lužan & Gangrena & $\begin{array}{c}19.11 . \\
1918 .\end{array}$ & $\begin{array}{c}13 \text { tabla } \\
7 \text { red } \\
\text { br. } 399\end{array}$ & $\begin{array}{l}\text { Počasni } \\
\text { grob }\end{array}$ \\
\hline 8 & 400 & $\begin{array}{l}\text { Leonard Šorša } \\
\text { pješak } 53 \text { puk. }\end{array}$ & $\begin{array}{l}39 \text { god. } \\
\text { oženjen } \\
\text { Cigrovec }\end{array}$ & Pregrada & Nefritis & $\begin{array}{l}20.11 . \\
1918 .\end{array}$ & $\begin{array}{c}13 \text { tabla } \\
7 \text { red } \\
\text { br. } 400\end{array}$ & $\begin{array}{l}\text { Počasni } \\
\text { grob }\end{array}$ \\
\hline 9 & 401 & $\begin{array}{c}\text { Vjekoslav } \\
\text { Hudika } \\
\text { dobrovoljac } \\
25 \text { dom. } \\
\text { pukovnije }\end{array}$ & $\begin{array}{c}18 \text { god. } \\
\text { neož } \\
\text { Budinščina }\end{array}$ & Budinščina & Upala pluća & $\begin{array}{l}21.11 . \\
1918 .\end{array}$ & $\begin{array}{c}13 \text { tabla } \\
7 \text { red } \\
\text { br. } 401\end{array}$ & $\begin{array}{l}\text { Počasni } \\
\text { grob }\end{array}$ \\
\hline 10 & 405 & $\begin{array}{l}\text { Ivan Gabrek } \\
\text { husar } 10 . \text { hus. } \\
\text { dom. puk. }\end{array}$ & $\begin{array}{l}28 \text { god. } \\
\text { neoženjen } \\
\text { Jalžabet }\end{array}$ & Jalžabet & $\begin{array}{l}\text { Upala (pluća), } \\
\text { tifus }\end{array}$ & $\begin{array}{l}23.11 . \\
1918 .\end{array}$ & $\begin{array}{c}13 \text { tabla } \\
7 \text { red } \\
\text { br. } 405\end{array}$ & $\begin{array}{l}\text { Počasni } \\
\text { grob }\end{array}$ \\
\hline 11 & 406 & $\begin{array}{c}\text { Dragomir } \\
\text { Lazić } \\
\text { pješak srpske } \\
\text { 19. pukovnije }\end{array}$ & $\begin{array}{l}31 \text { god. } \\
\text { neoženjen } \\
\text { Kruševo }\end{array}$ & Kruševo & Upala (pluća) & $\begin{array}{l}23.11 . \\
1918 .\end{array}$ & $\begin{array}{c}13 \text { tabla } \\
7 \text { red } \\
\text { br. } 406\end{array}$ & $\begin{array}{l}\text { Počasni } \\
\text { grob. } \\
\text { Vojnik } \\
\text { srpske } \\
\text { vojske }\end{array}$ \\
\hline 12 & 411 & $\begin{array}{c}\text { Jure Situm } \\
\text { pješak 22. pješ. } \\
\text { pukovnije }\end{array}$ & $\begin{array}{l}27 \text { god. } \\
\text { neoženjen } \\
\text { Cista }\end{array}$ & Cista & Upala (pluća) & $\begin{array}{l}30.11 . \\
1918 .\end{array}$ & $\begin{array}{l}13 \text { tabla } \\
7 \text { red } \\
\text { br. } 411\end{array}$ & $\begin{array}{l}\text { Počasni } \\
\text { grob }\end{array}$ \\
\hline 13 & 407 & $\begin{array}{l}\text { Ivan Pergan } \\
\text { vojnik } \\
\text { Narodne } \\
\text { vojske }\end{array}$ & $\begin{array}{c}25 \text { god. } \\
\text { neoženjen } \\
\text { Nedelišće }\end{array}$ & Nedelišće & (?) & $\begin{array}{c}25.11 . \\
1918 .\end{array}$ & $\begin{array}{c}13 \text { tabla } \\
7 \text { red } \\
\text { br. } 407\end{array}$ & $\begin{array}{l}\text { Počasni } \\
\text { grob }\end{array}$ \\
\hline 14 & 404 & $\begin{array}{c}\text { Leho Tropša } \\
\text { domobran } 25 \\
\text { dom. puk }\end{array}$ & $\begin{array}{l}23 \text { god. } \\
\text { neoženjen } \\
\text { Poturen }\end{array}$ & Čakovec & (?) & $\begin{array}{l}25.11 . \\
1918 .\end{array}$ & $\begin{array}{l}13 \text { tabla } \\
7 \text { red } \\
\text { br. } 404\end{array}$ & $\begin{array}{l}\text { Počasni } \\
\text { grob }\end{array}$ \\
\hline
\end{tabular}




\begin{tabular}{|c|c|c|c|c|c|c|c|c|}
\hline $\begin{array}{l}\text { Red. } \\
\text { broj }\end{array}$ & \begin{tabular}{|c|} 
Broj \\
groba
\end{tabular} & $\begin{array}{l}\text { Ime, prezime } \\
\text { i zanimanje }\end{array}$ & $\begin{array}{l}\text { doba, stališ } \\
\text { i rodno } \\
\text { mjesto }\end{array}$ & $\begin{array}{c}\text { mjesto } \\
\text { obitavanja }\end{array}$ & $\begin{array}{c}\text { posljednja } \\
\text { bolest } \\
\text { s koje je umro }\end{array}$ & $\begin{array}{c}\text { dan i } \\
\text { godina } \\
\text { kada je } \\
\text { sahranjen }\end{array}$ & Opazka & $\begin{array}{c}\text { Napomena } \\
\text { autora }\end{array}$ \\
\hline 15 & 402 & $\begin{array}{c}\text { Vjekoslav } \\
\text { Nemec } \\
\text { domobran } 25 \\
\text { dom. puk. }\end{array}$ & $\begin{array}{c}28 \text { god. } \\
\text { neoženjen } \\
\text { Dubovica }\end{array}$ & Dubovica & Upala (pluća) & $\begin{array}{l}22.11 . \\
1918 .\end{array}$ & $\begin{array}{c}13 \text { tabla } \\
7 \text { red } \\
\text { br. } 402\end{array}$ & $\begin{array}{l}\text { Počasni } \\
\text { grob }\end{array}$ \\
\hline 16 & 408 & $\begin{array}{l}\text { Blaž Stančić } \\
\text { domobran II/ } \\
25 \text { dom. Puk. }\end{array}$ & $\begin{array}{l}26 \text { god. } \\
\text { Jesovec }\end{array}$ & Jesovec & Upala (pluća) & $\begin{array}{l}28.11 . \\
1918 .\end{array}$ & $\begin{array}{c}13 \text { tabla } \\
7 \text { red } \\
\text { br. } 408\end{array}$ & $\begin{array}{c}\text { Počasni } \\
\text { grob }\end{array}$ \\
\hline 17 & 413 & $\begin{array}{c}\text { Ivan Bavol } \\
\text { pješak konjske } \\
\text { bolnice } \\
\text { Varaždin }\end{array}$ & $\begin{array}{l}23 \text { god. } \\
\text { neoženjen } \\
\text { (?) Novi }\end{array}$ & (?) Novi & $\begin{array}{c}\text { Gripa, } \\
\text { upala (pluća) }\end{array}$ & $\begin{array}{l}4.12 . \\
1918 .\end{array}$ & $\begin{array}{c}13 \text { tabla } \\
7 \text { red } \\
\text { br. } 413\end{array}$ & $\begin{array}{l}\text { Počasni } \\
\text { grob }\end{array}$ \\
\hline 18 & 412 & $\begin{array}{c}\text { Mihael Kerznar } \\
\text { pješak } 35 \text { pješ. } \\
\text { pukovnije }\end{array}$ & $\begin{array}{c}22 \text { god. } \\
\text { neoženjen } \\
\text { Gardinovec }\end{array}$ & Gardinovec & Gripa & $\begin{array}{l}1.12 . \\
1918 .\end{array}$ & $\begin{array}{c}13 \text { tabla } \\
7 \text { red } \\
\text { br. } 412\end{array}$ & $\begin{array}{l}\text { Počasni } \\
\text { grob }\end{array}$ \\
\hline 19 & 518 & $\begin{array}{c}\text { Dragutin } \\
\text { Mlakar } \\
\text { pješak od } 7 . \\
\text { polj. pukovnije }\end{array}$ & $\begin{array}{l}20 \text { god. } \\
\text { neoženjen } \\
\text { Trnovec }\end{array}$ & Trnovec & Gripa & $\begin{array}{l}2.12 . \\
1918 .\end{array}$ & $\begin{array}{c}\text { odpremljen } \\
\text { na ukop u } \\
\text { Bartolovec }\end{array}$ & \\
\hline 20 & 414 & $\begin{array}{c}\text { Dominik } \\
\text { Škrinjar } \\
\text { pješak } 53 \text { pješ. } \\
\text { pukovnije }\end{array}$ & $\begin{array}{l}31 \text { god. } \\
\text { oženjen } \\
\text { Bušin }\end{array}$ & Bušin & Upala pluća & $\begin{array}{l}7.12 . \\
1918 .\end{array}$ & $\begin{array}{c}13 \text { tabla } \\
8 \text { red } \\
\text { br. } 415\end{array}$ & $\begin{array}{l}\text { Počasni } \\
\text { grob }\end{array}$ \\
\hline 21 & 415 & $\begin{array}{l}\text { Matko Radović } \\
\text { vozar } 6 \text {. dom. } \\
\text { polj. topničke } \\
\text { pukovnije }\end{array}$ & $\begin{array}{l}42 \text { god. } \\
\text { oženjen } \\
\text { Grana } \\
\text { Novi Marof }\end{array}$ & Grana & Sepsa & $\begin{array}{l}13.12 . \\
1918 .\end{array}$ & $\begin{array}{c}13 \text { tabla } \\
7 \text { red } \\
\text { br. } 415\end{array}$ & $\begin{array}{l}\text { Počasni } \\
\text { grob }\end{array}$ \\
\hline 22 & 416 & \begin{tabular}{|c|} 
Miodrag \\
Đurović \\
pješak Serb. 12 \\
pukovnije
\end{tabular} & $\begin{array}{l}25 \text { god. } \\
\text { neoženjen } \\
\text { Kraljevo }\end{array}$ & Kraljevo & Gripa & $\begin{array}{l}18.12 . \\
1918 .\end{array}$ & $\begin{array}{c}13 \text { tabla } \\
7 \text { red } \\
\text { br. } 416\end{array}$ & $\begin{array}{l}\text { Počasni } \\
\text { grob }\end{array}$ \\
\hline
\end{tabular}




\begin{tabular}{|c|c|c|c|c|c|c|c|c|}
\hline $\begin{array}{l}\text { Red. } \\
\text { broj }\end{array}$ & \begin{tabular}{|c|} 
Broj \\
groba
\end{tabular} & $\begin{array}{l}\text { Ime, prezime } \\
\text { i zanimanje }\end{array}$ & $\begin{array}{l}\text { doba, stališ } \\
\text { i rodno } \\
\text { mjesto }\end{array}$ & $\begin{array}{c}\text { mjesto } \\
\text { obitavanja }\end{array}$ & $\begin{array}{c}\text { posljednja } \\
\text { bolest } \\
\text { s koje je umro }\end{array}$ & $\begin{array}{c}\text { dan i } \\
\text { godina } \\
\text { kada je } \\
\text { sahranjen }\end{array}$ & Opazka & $\begin{array}{l}\text { Napomena } \\
\text { autora }\end{array}$ \\
\hline 23 & 418 & $\begin{array}{c}\text { Juraj Pejnović } \\
\text { (?) } 10 \text { hus } \\
\text { pukovnija }\end{array}$ & $\begin{array}{l}36 \text { god. } \\
\text { neoženjen } \\
\text { Smiljan }\end{array}$ & $\begin{array}{l}\text { Smiljan } \\
\text { Gospić }\end{array}$ & Tuberkuloza & $\begin{array}{l}31.1 . \\
1918 .\end{array}$ & $\begin{array}{c}13 \text { tabla } \\
7 \text { red } \\
\text { br. } 418\end{array}$ & $\begin{array}{l}\text { Počasni } \\
\text { grob }\end{array}$ \\
\hline 24 & 12 & $\begin{array}{c}\text { Ladislav } \\
\text { Matuzlenac } \\
\text { stražmeštar } \\
\text { kod konjice }\end{array}$ & $\begin{array}{l}42 \text { god. } \\
\text { oženjen } \\
\text { Brdovec }\end{array}$ & Varaždin & (?) & $\begin{array}{l}10.3 . \\
1919 .\end{array}$ & $\begin{array}{c}13 \text { tabla } \\
12 \text { red } \\
\text { br. } 12\end{array}$ & $\begin{array}{l}\text { Počasni } \\
\text { grob }\end{array}$ \\
\hline 25 & 12 & $\begin{array}{l}\text { Vjekoslav } \\
\text { Svačko } \\
\text { računarski } \\
\text { podčasnik }\end{array}$ & $\begin{array}{l}30 \text { god. } \\
\text { neoženjen } \\
\text { Varaždin }\end{array}$ & Varaždin & Tuberkuloza & $\begin{array}{l}16.3 . \\
1919 .\end{array}$ & $\begin{array}{c}13 \text { tabla } \\
11 \text { red } \\
\text { br. } 12\end{array}$ & $\begin{array}{c}\text { Počasni } \\
\text { grob }\end{array}$ \\
\hline 26 & 255 & $\begin{array}{c}\text { Popović } \\
\text { Danilo } \\
\text { srbski } \\
\text { zarobljenik }\end{array}$ & $\begin{array}{c}19 \mathrm{~g} \\
\text { neoženjen } \\
\text { Kragujevac }\end{array}$ & Kragujevac & Tuberkuloza & $\begin{array}{l}10.10 . \\
1917 .\end{array}$ & $\begin{array}{l}18 \text { tabla } \\
3 \text { red } \\
\text { br. } 255\end{array}$ & $\begin{array}{c}\text { Počasni } \\
\text { grob. } \\
\text { Isti upis u: } \\
\text { 345. Knjiga } \\
\text { mrtvacah } \\
\text { obiteljskih } \\
\text { grobnica } \\
\text { 1902.-1919. } \\
\text { red. br. } 308\end{array}$ \\
\hline 27 & 264 & $\begin{array}{l}\text { Stojanović } \\
\text { Blagoje } \\
\text { srpski } \\
\text { zarobljenik }\end{array}$ & $\begin{array}{c}17 \mathrm{~g} \\
\text { neoženjen } \\
\text { (Beograd, } \\
\text { Srbija) }\end{array}$ & (?) & Tuberkuloza & $\begin{array}{l}19.11 . \\
1917 .\end{array}$ & $\begin{array}{l}18 \text { tabla } \\
2 \text { red } \\
\text { br. } 264\end{array}$ & $\begin{array}{c}\text { Počasni } \\
\text { grob. } \\
\text { Isti upis u: } \\
\text { 345. Knjiga } \\
\text { mrtvacah } \\
\text { obiteljskih } \\
\text { grobnica } \\
\text { 1902.-1919. } \\
\text { red. br. } 320\end{array}$ \\
\hline 28 & 266 & $\begin{array}{c}\text { Sajić } \\
\text { Alexander } \\
\text { srpski } \\
\text { zarobljenik }\end{array}$ & $\begin{array}{c}17 \mathrm{~g} \\
\text { neoženjen } \\
(?)\end{array}$ & Varaždin & Tuberkuloza & $\begin{array}{l}3.12 . \\
1917 .\end{array}$ & $\begin{array}{c}17 \text { tabla } \\
3 \text { red } \\
\text { br. } 266\end{array}$ & $\begin{array}{l}\text { Počasni } \\
\text { grob }\end{array}$ \\
\hline 29 & 1404 & $\begin{array}{l}\text { Pupeš Šandor } \\
\text { vojnik kr. } \\
\text { dom. } 10 \text { hus. } \\
\text { pukovnije }\end{array}$ & $\begin{array}{l}30 \text { god. } \\
\text { oženjen } \\
\text { Grubišno } \\
\text { Polje }\end{array}$ & $\begin{array}{l}\text { Grubišno } \\
\text { Polje }\end{array}$ & (?) & 6. 8. 1915. & $\begin{array}{c}16 \text { tabla } \\
8 \text { red } \\
\text { br. } 1404\end{array}$ & $\begin{array}{c}\text { Isti upis } \\
\text { u: Knjiga } \\
\text { mrtvacah } \\
\text { občenitih } \\
\text { grobova } \\
\text { 1902.. } \\
\text { red. br. } 538\end{array}$ \\
\hline 30 & 1388 & $\begin{array}{l}\text { Štimac Stjepan } \\
\text { porućnik c. i k. } \\
\text { 79. pješ. puk. } \\
\text { I. dokadne } \\
\text { satnije }\end{array}$ & $\begin{array}{c}32 \text { god. } \\
\text { neoženjen } \\
\text { Brod na Savi }\end{array}$ & $\begin{array}{c}\text { Brod na } \\
\text { Savi }\end{array}$ & Meningitis & $\begin{array}{l}14.6 . \\
1915 .\end{array}$ & $\begin{array}{c}16 \text { tabla } \\
9 \text { red } \\
\text { br. } 1381\end{array}$ & $\begin{array}{c}\text { Isti upis } \\
\text { u: Knjiga } \\
\text { mrtvacah } \\
\text { občenitih } \\
\text { grobova } \\
\text { 1902.. } \\
\text { red. br. } 506\end{array}$ \\
\hline
\end{tabular}




\begin{tabular}{|c|c|c|c|c|c|c|c|c|}
\hline $\begin{array}{l}\text { Red. } \\
\text { broj }\end{array}$ & $\begin{array}{c}\text { Broj } \\
\text { groba }\end{array}$ & $\begin{array}{l}\text { Ime, prezime } \\
\text { i zanimanje }\end{array}$ & $\begin{array}{l}\text { doba, stališ } \\
\text { i rodno } \\
\text { mjesto }\end{array}$ & $\begin{array}{c}\text { mjesto } \\
\text { obitavanja }\end{array}$ & $\begin{array}{c}\text { posljednja } \\
\text { bolest } \\
\text { s koje je umro }\end{array}$ & $\begin{array}{c}\text { dan i } \\
\text { godina } \\
\text { kada je } \\
\text { sahranjen }\end{array}$ & Opazka & $\begin{array}{l}\text { Napomena } \\
\text { autora }\end{array}$ \\
\hline 31 & 1368 & $\begin{array}{l}\text { Herceg Stjepan } \\
\text { (?) ulan c. i } \\
\text { k. 5. ulan. } \\
\text { pukovnije } \\
\text { dok. (?) }\end{array}$ & $\begin{array}{c}26 \text { god. } \\
\text { neoženjen } \\
\text { Veliki } \\
\text { Novaki } \\
\text { kotar Ivanec }\end{array}$ & $\begin{array}{c}\text { Veliki } \\
\text { Novaki } \\
\text { kotar } \\
\text { Ivanec } \\
\text { umro u c. } \\
\text { i k. prič. } \\
\text { bolnici } \\
\text { ovdje }\end{array}$ & Meningitis & $\begin{array}{l}13.5 . \\
1915 .\end{array}$ & $\begin{array}{c}16 \text { tabla } \\
8 \text { red } \\
\text { br. } 1368\end{array}$ & $\begin{array}{c}\text { Isti upis } \\
\text { u: Knjiga } \\
\text { mrtvacah } \\
\text { občenitih } \\
\text { grobova } \\
\text { 1902., } \\
\text { red. br. } 484\end{array}$ \\
\hline 32 & 1355 & $\begin{array}{l}\text { Žagar Mato } \\
\text { vojnik kr. } \\
\text { husar. dom. } \\
\text { 10. puk. dom. } \\
\text { satnije }\end{array}$ & $\begin{array}{l}27 \text { god. } \\
\text { oženjen }\end{array}$ & $\begin{array}{c}\text { Nova } \\
\text { Bukovica } \\
\text { kotar } \\
\text { Slatina } \\
\text { Hrvatska }\end{array}$ & Upala pluća & $\begin{array}{l}21.4 . \\
1915 .\end{array}$ & $\begin{array}{c}16 \text { tabla } \\
7 \text { red } \\
\text { br. } 1355\end{array}$ & $\begin{array}{c}\text { Isti upis } \\
\text { u: Knjiga } \\
\text { mrtvacah } \\
\text { občenitih } \\
\text { grobova } \\
\text { 1902., } \\
\text { red. br. } 461\end{array}$ \\
\hline 33 & 1294 & $\begin{array}{c}\text { Peterica Jakob } \\
\text { pučki ustaša } \\
\text { bolničar (?) }\end{array}$ & $\begin{array}{c}25 \text { god. } \\
\text { neoženjen } \\
\text { Studenci } \\
\text { Marija Polje } \\
\text { Kranjska }\end{array}$ & $\begin{array}{l}\text { Studenci } \\
\text { Marija } \\
\text { Polje } \\
\text { Kranjska / } \\
\text { umro } \\
\text { u prič. } \\
\text { bolnici }\end{array}$ & Tifus & 9.2.1915. & $\begin{array}{l}16 \text { tabla } \\
5 \text { red } \\
\text { br. } 1294\end{array}$ & \\
\hline 34 & 1292 & $\begin{array}{c}\text { Jakopčić } \\
\text { Stjepan pl. } \\
\text { pučki ustaša } \\
\text { bolnički (?) }\end{array}$ & $\begin{array}{l}30 \text { god. } \\
\text { neoženjen } \\
\text { Zlatar }\end{array}$ & & Tifus & 9.2. 1915. & $\begin{array}{c}16 \text { tabla } \\
5 \text { red } \\
\text { br. } 1292\end{array}$ & \\
\hline 35 & 1283 & $\begin{array}{c}\text { Kos Grga } \\
\text { pučko ustaški } \\
\text { obveznik } \\
\text { bolničar } \\
\text { c. i k. pričuv. } \\
\text { bolnice }\end{array}$ & $\begin{array}{c}38 \text { god. } \\
\text { oženjen } \\
\text { Ivanec } \\
\text { kotar Ivanec }\end{array}$ & $\begin{array}{l}\text { Varaždin } \\
\text { Murvinjak }\end{array}$ & Tifus & $\begin{array}{l}30.1 . \\
1915 .\end{array}$ & $\begin{array}{c}16 \text { tabla } \\
5 \text { red } \\
\text { br. } 1283\end{array}$ & \\
\hline 36 & 1273 & $\begin{array}{c}\text { Mandekić } \\
\text { Gjuro } \\
\text { c. i k. oružnik } \\
\text { počastn. } \\
\text { vodnik (?) }\end{array}$ & $\begin{array}{c}25 \text { god. } \\
\text { star } \\
\text { neoženjen } \\
\text { Pazariđte } \\
\text { kotar Požega }\end{array}$ & $\begin{array}{c}\text { Pazarište } \\
\text { umro u } \\
\text { Varaždinu } \\
\text { c. i k. } \\
\text { ug. prič. } \\
\text { bolnica }\end{array}$ & Tifus & $\begin{array}{l}24.1 . \\
1915 .\end{array}$ & $\begin{array}{l}16 \text { tabla } \\
5 \text { red } \\
\text { br. } 1273\end{array}$ & \\
\hline
\end{tabular}




\begin{tabular}{|c|c|c|c|c|c|c|c|c|}
\hline $\begin{array}{l}\text { Red. } \\
\text { broj }\end{array}$ & $\begin{array}{c}\text { Broj } \\
\text { groba }\end{array}$ & $\begin{array}{c}\text { Ime, prezime } \\
\text { i zanimanje }\end{array}$ & $\begin{array}{l}\text { doba, stališ } \\
\text { i rodno } \\
\text { mjesto }\end{array}$ & $\begin{array}{c}\text { mjesto } \\
\text { obitavanja }\end{array}$ & $\begin{array}{c}\text { posljednja } \\
\text { bolest } \\
\text { s koje je umro }\end{array}$ & $\begin{array}{c}\text { dan i } \\
\text { godina } \\
\text { kada je } \\
\text { sahranjen }\end{array}$ & Opazka & $\begin{array}{l}\text { Napomena } \\
\text { autora }\end{array}$ \\
\hline 37 & 1232 & $\begin{array}{c}\text { Benčić Martin } \\
\text { vojnik }\end{array}$ & $\begin{array}{c}35 \text { god. } \\
\text { oženjen } \\
\text { Kneginec }\end{array}$ & $\begin{array}{c}\text { Kneginec } \\
\text { umro u c. i } \\
\text { kr. Ug. } \\
\text { pričuvnoj } \\
\text { bolnici u } \\
\text { Varaždinu }\end{array}$ & Tuberkuloza & $\begin{array}{l}27.2 . \\
1914 .\end{array}$ & $\begin{array}{c}16 \text { tabla } \\
5 \text { red } \\
\text { br. } 1232\end{array}$ & \\
\hline 38 & 1205 & $\begin{array}{l}\text { Gorički Vilim } \\
\text { c. i k. topnik } \\
\text { (kanonier) }\end{array}$ & $\begin{array}{l}\text { Jaljše (?) } \\
\text { Klanjec } \\
\text { Hrvatska }\end{array}$ & Varaždin & $\begin{array}{c}\text { Samoubojstvo } \\
\text { (objesio se) }\end{array}$ & $\begin{array}{l}16.10 . \\
1914 .\end{array}$ & $\begin{array}{c}16 \text { tabla } \\
5 \text { red } \\
\text { br. } 1205\end{array}$ & \\
\hline 39 & 1199 & $\begin{array}{l}\text { Pisuljak Petar } \\
\text { c. i kr. (ulan) } \\
\text { kopljanik }\end{array}$ & \begin{tabular}{|c|}
22 god. \\
star \\
Sv. Šimun (?) \\
Zagreb
\end{tabular} & $\begin{array}{l}\text { Varaždin } \\
\text { umro u } \\
\text { c. i kr. } \\
\text { Pričuvnoj } \\
\text { bolnici (?) }\end{array}$ & Dizenterija & $\begin{array}{l}29.9 . \\
1914 .\end{array}$ & $\begin{array}{l}16 \text { tabla } \\
1 \text { red } \\
\text { br. } 1201\end{array}$ & \\
\hline 40 & 1450 & $\begin{array}{c}\text { Pallaš Tomo } \\
\text { vojnički } \\
\text { nemoćnik }\end{array}$ & $\begin{array}{c}85 \text { god. } \\
\text { udovac } \\
\text { Peteranec } \\
\text { (Koprivnica) }\end{array}$ & $\begin{array}{l}\text { Varaždin } \\
\text { umro u } \\
\text { vojnoj } \\
\text { četnoj } \\
\text { bolnici u } \\
\text { Varaždinu }\end{array}$ & Upala pluća & $\begin{array}{l}30.6 . \\
1914 .\end{array}$ & $\begin{array}{c}16 \text { tabla } \\
1 \text { red } \\
\text { br. } 1450\end{array}$ & \\
\hline 41 & 1068 & $\begin{array}{c}\text { Georg Jäger } \\
\text { ulan c. i k. 5/ } \\
13 \text { (?) }\end{array}$ & $\begin{array}{c}18 \text { god. } \\
\text { neoženjen } \\
\text { Vukovar }\end{array}$ & $\begin{array}{l}\text { Varaždin } \\
\text { umro u c. } \\
\text { i kr. četnoj } \\
\text { bolnici u } \\
\text { Varaždinu }\end{array}$ & Upala pluća & 9.3. 1914. & $\begin{array}{c}7 \text { tabla } \\
1 \text { red } \\
\text { br. } 1068\end{array}$ & \\
\hline 42 & 1072 & $\begin{array}{c}\text { Kokanović } \\
\text { Mato } \\
\text { c. i kr. Topnik }\end{array}$ & $\begin{array}{l}22 \text { god. } \\
\text { neoženjen } \\
\text { Gundinci } \\
\text { kotar } \\
\text { Županja }\end{array}$ & $\begin{array}{c}\text { Varaždin } \\
\text { umro u c. } \\
\text { i kr. } \\
\text { ćetnoj } \\
\text { bolnici }\end{array}$ & Tuberkuloza & $\begin{array}{l}10.3 . \\
1914 .\end{array}$ & $\begin{array}{c}7 \text { tabla } \\
1 \text { red } \\
\text { br. } 1072\end{array}$ & \\
\hline 43 & 1059 & $\begin{array}{l}\text { Benjak Gjuro } \\
\text { kr. domobran. } \\
\text { husar. puk. } 10\end{array}$ & $\begin{array}{c}22 \text { god. } \\
\text { neoženjen } \\
\text { Remetinec } \\
\text { kotar Novi } \\
\text { Marof }\end{array}$ & $\begin{array}{l}\text { Varaždin } \\
\text { umro u c. i } \\
\text { kr. Vojnoj } \\
\text { bolnici }\end{array}$ & $\begin{array}{l}\text { Prijelom } \\
\text { kralježnice }\end{array}$ & $\begin{array}{l}25.2 . \\
1914 .\end{array}$ & $\begin{array}{c}7 \text { tabla } \\
1 \text { red } \\
\text { br. } 1067\end{array}$ & \\
\hline
\end{tabular}




\begin{tabular}{|c|c|c|c|c|c|c|c|c|}
\hline $\begin{array}{l}\text { Red. } \\
\text { broj }\end{array}$ & $\begin{array}{c}\text { Broj } \\
\text { groba }\end{array}$ & $\begin{array}{l}\text { Ime, prezime } \\
\text { i zanimanje }\end{array}$ & $\begin{array}{l}\text { doba, stališ } \\
\text { i rodno } \\
\text { mjesto }\end{array}$ & $\begin{array}{c}\text { mjesto } \\
\text { obitavanja }\end{array}$ & $\begin{array}{c}\text { posljednja } \\
\text { bolest } \\
\text { s koje je umro }\end{array}$ & $\begin{array}{c}\text { dan i } \\
\text { godina } \\
\text { kada je } \\
\text { sahranjen }\end{array}$ & Opazka & $\begin{array}{l}\text { Napomena } \\
\text { autora }\end{array}$ \\
\hline 44 & 199 & $\begin{array}{l}\text { Horvat Janos } \\
\text { vojnik pješak }\end{array}$ & $?$ & Beretinec & (?) & $\begin{array}{l}21.8 . \\
1917 .\end{array}$ & $\begin{array}{c}18 \text { tabla } \\
2 \text { red } \\
\text { br. } 199\end{array}$ & $\begin{array}{c}\text { Počasni } \\
\text { grob. } \\
\text { Isti upis u: } \\
\text { 345. Knjiga } \\
\text { mrtvacah } \\
\text { obiteljskih } \\
\text { grobnica } \\
\text { 1902.-1919., } \\
\text { red. br. } 221\end{array}$ \\
\hline 45 & 198 & $\begin{array}{l}\text { Pribilović Juro } \\
\text { vojnik pješak }\end{array}$ & $\begin{array}{c}20 \text { god. } \\
\text { neoženjen } \\
\text { (?) }\end{array}$ & (?) & Tuberkuloza & $\begin{array}{l}20.5 . \\
1917 .\end{array}$ & $\begin{array}{c}18 \text { tabla } \\
2 \text { red } \\
\text { br. } 198\end{array}$ & $\begin{array}{c}\text { Počasni } \\
\text { grob. } \\
\text { Isti upis u: } \\
\text { 345. Knjiga } \\
\text { mrtvacah } \\
\text { obiteljskih } \\
\text { grobnica } \\
\text { 1902.-1919., } \\
\text { red. br. } 220\end{array}$ \\
\hline 46 & 200 & $\begin{array}{c}\text { Kozmina } \\
\text { Valentin } \\
\text { vojnik topnik }\end{array}$ & $?$ & $?$ & (?) & $\begin{array}{l}21.5 . \\
1917 .\end{array}$ & $\begin{array}{c}18 \text { tabla } \\
2 \text { red } \\
\text { br. } 200\end{array}$ & $\begin{array}{c}\text { Počasni } \\
\text { grob. } \\
\text { Isti upis u: } \\
\text { 345. Knjiga } \\
\text { mrtvacah } \\
\text { obiteljskih } \\
\text { grobnica } \\
\text { 1902.-1919., } \\
\text { red. br. } 222\end{array}$ \\
\hline 47 & 201 & $\begin{array}{l}\text { Šmerka Johan } \\
\text { vojnik topnik }\end{array}$ & $\begin{array}{l}45 \text { god. } \\
\text { oženjen } \\
(?)\end{array}$ & (?) & Upala pluća & $\begin{array}{l}22.5 . \\
1917 .\end{array}$ & $\begin{array}{c}13 \text { tabla } \\
3 \text { red } \\
\text { br. } 201\end{array}$ & $\begin{array}{l}\text { Počasni } \\
\text { grob }\end{array}$ \\
\hline 48 & 196 & $\begin{array}{l}\text { Horvat Jakob } \\
\text { vojnik pješak }\end{array}$ & $\begin{array}{c}\text { Vratno } \\
25 \text { god. } \\
\text { neoženjen }\end{array}$ & Vratno & Upala pluća & $\begin{array}{l}19.5 . \\
1917 .\end{array}$ & $\begin{array}{c}13 \text { tabla } \\
2 \text { red } \\
\text { br. } 196\end{array}$ & $\begin{array}{c}\text { Počasni } \\
\text { grob. } \\
\text { Isti upis u: } \\
\text { 345. Knjiga } \\
\text { mrtvacah } \\
\text { obiteljskih } \\
\text { grobnica } \\
\text { 1902.-1919., } \\
\text { red. br. } 218\end{array}$ \\
\hline 49 & 195 & $\begin{array}{l}\text { Prelec Gjuro } \\
\text { vojnik topnik }\end{array}$ & $\begin{array}{l}42 \text { god. } \\
\text { Baničevci }\end{array}$ & Baničevci & Upala pluća & 3. 5. 1917. & $\begin{array}{c}13 \text { tabla } \\
2 \text { red } \\
\text { br. } 195\end{array}$ & $\begin{array}{c}\text { Počasni } \\
\text { grob. } \\
\text { Isti upis u: } \\
\text { 345. Knjiga } \\
\text { mrtvacah } \\
\text { obiteljskih } \\
\text { grobnica } \\
\text { 1902.-1919., } \\
\text { red. br. } 217\end{array}$ \\
\hline
\end{tabular}




\begin{tabular}{|c|c|c|c|c|c|c|c|c|}
\hline $\begin{array}{l}\text { Red. } \\
\text { broj }\end{array}$ & $\begin{array}{c}\text { Broj } \\
\text { groba }\end{array}$ & $\begin{array}{l}\text { Ime, prezime } \\
\text { i zanimanje }\end{array}$ & $\begin{array}{l}\text { doba, stališ } \\
\text { i rodno } \\
\text { mjesto }\end{array}$ & $\begin{array}{c}\text { mjesto } \\
\text { obitavanja }\end{array}$ & $\begin{array}{c}\text { posljednja } \\
\text { bolest } \\
\text { s koje je umro }\end{array}$ & $\begin{array}{c}\text { dan i } \\
\text { godina } \\
\text { kada je } \\
\text { sahranjen }\end{array}$ & Opazka & $\begin{array}{c}\text { Napomena } \\
\text { autora }\end{array}$ \\
\hline 50 & 197 & $\begin{array}{c}\text { Alneković } \\
\text { Antun } \\
\text { vojnik pješak }\end{array}$ & 42 god. & Bresino & Tuberkuloza & 5.5.1917. & $\begin{array}{c}13 \text { tabla } \\
2 \text { red } \\
\text { br. } 197\end{array}$ & $\begin{array}{l}\text { Počasni } \\
\text { grob }\end{array}$ \\
\hline 51 & 192 & $\begin{array}{c}\text { Kirin Vicko } \\
\text { vojnik pješak }\end{array}$ & $\begin{array}{l}21 \text { god. } \\
\text { neoženjen } \\
\text { Spljet }\end{array}$ & Spljet & Upala pluća & $\begin{array}{l}27.4 . \\
1917 .\end{array}$ & $\begin{array}{l}13 \text { tabla } \\
2 \text { red } \\
\text { br. } 192\end{array}$ & $\begin{array}{c}\text { Počasni } \\
\text { grob. } \\
\text { Isti upis u: } \\
\text { 345. Knjiga } \\
\text { mrtvacah } \\
\text { obiteljskih } \\
\text { grobnica } \\
\text { 1902.-1919. } \\
\text { red. br. } 214\end{array}$ \\
\hline 52 & 190 & $\begin{array}{l}\text { Moženić Mato } \\
\text { vojnik topnik }\end{array}$ & $\begin{array}{l}21 \text { god. } \\
\text { neoženjen } \\
\text { Selnik }\end{array}$ & Selnik & Tuberkuloza & $\begin{array}{l}26.4 . \\
1917 .\end{array}$ & $\begin{array}{l}13 \text { tabla } \\
2 \text { red } \\
\text { br. } 190\end{array}$ & $\begin{array}{c}\text { Počasni } \\
\text { grob. } \\
\text { Isti upis u: } \\
\text { 345. Knjiga } \\
\text { mrtvacah } \\
\text { obiteljskih } \\
\text { grobnica } \\
\text { 1902.-1919. } \\
\text { red. br. } 212\end{array}$ \\
\hline 53 & 191 & $\begin{array}{l}\text { Lipak Pavao } \\
\text { vojnik topnik }\end{array}$ & $\begin{array}{l}18 \text { god. } \\
\text { neoženjen } \\
\text { Svinjičko }\end{array}$ & Svinjičko & Upala pluća & $\begin{array}{l}27.4 . \\
1917 .\end{array}$ & $\begin{array}{l}13 \text { tabla } \\
2 \text { red } \\
\text { br. } 191\end{array}$ & 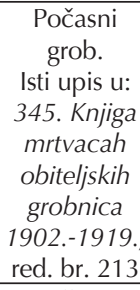 \\
\hline 54 & 187 & $\begin{array}{c}\text { Disdarević } \\
\text { Maše } \\
\text { vojnik pješak }\end{array}$ & $\begin{array}{l}40 \text { god. } \\
\text { oženjen } \\
(?)\end{array}$ & (?) & Opća slabost & $\begin{array}{l}11.4 . \\
1917 .\end{array}$ & $\begin{array}{l}13 \text { tabla } \\
2 \text { red } \\
\text { br. } 187\end{array}$ & $\begin{array}{c}\text { Počasni } \\
\text { grob. } \\
\text { Isti upis u: } \\
\text { 345. Knjiga } \\
\text { mrtvacah } \\
\text { obiteljskih } \\
\text { grobnica } \\
\text { 1902.-1919. } \\
\text { red. br. } 208 \\
\end{array}$ \\
\hline 55 & 188 & $\begin{array}{l}\text { Gudelj Imbro } \\
\text { vojnik topnik }\end{array}$ & $\begin{array}{l}24 \text { god. } \\
\text { neoženjen } \\
\text { Jalkovec }\end{array}$ & Jalkovec & Tuberkuloza & $\begin{array}{l}18.4 . \\
1917 .\end{array}$ & $\begin{array}{c}13 \text { tabla } \\
1 \text { red } \\
\text { br. } 188\end{array}$ & $\begin{array}{c}\text { Počasni } \\
\text { grob. } \\
\text { Isti upis u: } \\
\text { 345. Knjiga } \\
\text { mrtvacah } \\
\text { obiteljskih } \\
\text { grobnica } \\
\text { 1902.-1919. } \\
\text { red. br. } 209\end{array}$ \\
\hline
\end{tabular}




\begin{tabular}{|c|c|c|c|c|c|c|c|c|}
\hline $\begin{array}{l}\text { Red. } \\
\text { broj }\end{array}$ & $\begin{array}{c}\text { Broj } \\
\text { groba }\end{array}$ & $\begin{array}{l}\text { Ime, prezime } \\
\text { i zanimanje }\end{array}$ & $\begin{array}{c}\text { doba, stališ } \\
\text { i rodno } \\
\text { mjesto }\end{array}$ & $\begin{array}{c}\text { mjesto } \\
\text { obitavanja }\end{array}$ & $\begin{array}{c}\text { posljednja } \\
\text { bolest } \\
\text { s koje je umro }\end{array}$ & $\begin{array}{c}\text { dan i } \\
\text { godina } \\
\text { kada je } \\
\text { sahranjen }\end{array}$ & Opazka & $\begin{array}{l}\text { Napomena } \\
\text { autora }\end{array}$ \\
\hline 56 & 186 & $\begin{array}{c}\text { Plenuić Ivo } \\
\text { vojnik }\end{array}$ & $\begin{array}{c}22 \mathrm{~g} \\
\text { neoženjen } \\
\text { Priselka } \\
\text { Bosna }\end{array}$ & Priselka & Tuberkuloza & $\begin{array}{l}26.3 . \\
1917 .\end{array}$ & $\begin{array}{c}13 \text { tabla } \\
1 \text { red } \\
\text { br. } 186\end{array}$ & $\begin{array}{l}\text { Počasni } \\
\text { grob }\end{array}$ \\
\hline 57 & 181 & $\begin{array}{l}\text { Zajec August } \\
\text { vojnik }\end{array}$ & $\begin{array}{c}25 \text { god. } \\
\text { neoženjen } \\
\text { Velika Ves }\end{array}$ & Velika Ves & Tuberkuloza & $\begin{array}{l}28.2 . \\
1917 .\end{array}$ & $\begin{array}{c}13 \text { tabla } \\
1 \text { red } \\
\text { br. } 181\end{array}$ & $\begin{array}{c}\text { Počasni } \\
\text { grob. } \\
\text { Isti upis u: } \\
\text { 345. Knjiga } \\
\text { mrtvacah } \\
\text { obiteljskih } \\
\text { grobnica } \\
\text { 1902.-1919., } \\
\text { red. br. } 202\end{array}$ \\
\hline 58 & 158 & $\begin{array}{c}\text { Flansar Franjo } \\
\text { pješak }\end{array}$ & $\begin{array}{l}42 \text { god. } \\
\text { oženjen } \\
\text { Plešivica }\end{array}$ & Plešivica & $\begin{array}{c}\text { Prostrijelna } \\
\text { rana } \\
\text { na nozi }\end{array}$ & $\begin{array}{l}26.10 . \\
1916 .\end{array}$ & $\begin{array}{c}13 \text { tabla } \\
8 \text { red } \\
\text { br. } 159\end{array}$ & $\begin{array}{l}\text { Počasni } \\
\text { grob }\end{array}$ \\
\hline 59 & 155 & $\begin{array}{l}\text { Slivar Andrija } \\
\text { pučki ustaša }\end{array}$ & $\begin{array}{l}47 \text { god. } \\
\text { oženjen } \\
\text { (?) Ivanec }\end{array}$ & (?) & Meningitis & $\begin{array}{l}7.10 . \\
1916 .\end{array}$ & $\begin{array}{l}15 \text { tabla } \\
8 \text { red } \\
\text { br. } 155\end{array}$ & $\begin{array}{c}\text { Počasni } \\
\text { grob. Isti } \\
\text { upis u: } \\
\text { Knjiga } \\
\text { mrtvacah } \\
\text { občenitih } \\
\text { grobova } \\
\text { 1902., } \\
\text { red. br. } 204\end{array}$ \\
\hline 60 & 148 & $\begin{array}{c}\text { Orlovski Petar } \\
\text { infanterist }\end{array}$ & $\begin{array}{l}34 \text { god. } \\
\text { oženjen } \\
\text { Dubovec }\end{array}$ & Dubovec & $\begin{array}{l}\text { Prostrijelna } \\
\text { rana }\end{array}$ & 8. 7. 1916. & $\begin{array}{c}13 \text { tabla } \\
7 \text { red } \\
\text { br. } 148\end{array}$ & $\begin{array}{c}\text { Počasni } \\
\text { grob. Isti } \\
\text { upis u: } \\
\text { 345. Knjiga } \\
\text { mrtvacah } \\
\text { obiteljskih } \\
\text { grobnica } \\
\text { 1902.-1919., } \\
\text { red. br. } 166\end{array}$ \\
\hline 61 & 1363 & $\begin{array}{l}\text { Ezer Gjuro } \\
\text { topnik }\end{array}$ & $\begin{array}{l}47 \text { god. } \\
\text { oženjen } \\
\text { Šenkovci }\end{array}$ & Šenkovci & (?) & $\begin{array}{l}15.9 . \\
1916 .\end{array}$ & $\begin{array}{c}15 \text { tabla } \\
9 \text { red } \\
\text { br. } 1363\end{array}$ & $\begin{array}{c}\text { Počasni } \\
\text { grob. Isti } \\
\text { upis u: } \\
\text { Knjiga } \\
\text { mrtvacah } \\
\text { občenitih } \\
\text { grobova } \\
\text { 1902., } \\
\text { red. br. } 194\end{array}$ \\
\hline
\end{tabular}




\begin{tabular}{|c|c|c|c|c|c|c|c|c|}
\hline $\begin{array}{l}\text { Red. } \\
\text { broj }\end{array}$ & $\begin{array}{c}\text { Broj } \\
\text { groba }\end{array}$ & $\begin{array}{l}\text { Ime, prezime } \\
\text { i zanimanje }\end{array}$ & $\begin{array}{l}\text { doba, stališ } \\
\text { i rodno } \\
\text { mjesto }\end{array}$ & $\begin{array}{c}\text { mjesto } \\
\text { obitavanja }\end{array}$ & $\begin{array}{c}\text { posljednja } \\
\text { bolest } \\
\text { s koje je umro }\end{array}$ & $\begin{array}{c}\text { dan i } \\
\text { godina } \\
\text { kada je } \\
\text { sahranjen }\end{array}$ & Opazka & $\begin{array}{l}\text { Napomena } \\
\text { autora }\end{array}$ \\
\hline 62 & 150 & $\begin{array}{l}\text { Roslek Viktor } \\
\text { (?) stražmeštar }\end{array}$ & $\begin{array}{l}41 \text { god. } \\
\text { oženjen } \\
\text { Sv. Juraj }\end{array}$ & Varaždin & Tuberkuloza & $\begin{array}{l}24.9 . \\
1916 .\end{array}$ & $\begin{array}{l}15 \text { tabla } \\
9 \text { red } \\
\text { br. } 150\end{array}$ & $\begin{array}{c}\text { Počasni } \\
\text { grob. Isti } \\
\text { upis u: } \\
\text { 345. Knjiga } \\
\text { mrtvacah } \\
\text { obiteljskih } \\
\text { grobnica } \\
\text { 1902.-1919., } \\
\text { red. br. } 168 \\
\end{array}$ \\
\hline 63 & 1300 & $\begin{array}{c}\text { Dragić Ivan } \\
\text { vojnik ratnik }\end{array}$ & $\begin{array}{l}51 \text { god. } \\
\text { oženjen } \\
\text { Slunja }\end{array}$ & Slunja & Ospice & $\begin{array}{l}20.7 . \\
1916 .\end{array}$ & $\begin{array}{c}15 \text { tabla } \\
4 \text { red } \\
\text { br. } 1337\end{array}$ & \\
\hline 64 & 339 & $\begin{array}{c}\text { Katuša Ivan } \\
\text { vojnik pješak }\end{array}$ & $\begin{array}{c}21 \text { god. } \\
\text { neoženjen } \\
\text { Medvidja } \\
\text { Obrovac } \\
\text { Benkovac } \\
\text { Dalmacija }\end{array}$ & Medvidja & Tuberkuloza & $\begin{array}{l}25.7 . \\
1916 .\end{array}$ & $\begin{array}{c}15 \text { tabla } \\
10 \text { red } \\
\text { br. } 1339\end{array}$ & $\begin{array}{c}\text { Isti upis } \\
\text { u: Knjiga } \\
\text { mrtvacah } \\
\text { občenitih } \\
\text { grobova } \\
\text { 1902., } \\
\text { red. br. } 159\end{array}$ \\
\hline 65 & 113 & $\begin{array}{c}\text { Kolarić Ivan } \\
\text { vojnik } \\
\text { poljodjelac }\end{array}$ & $\begin{array}{l}35 \text { god. } \\
\text { oženjen } \\
\text { Velika } \\
\text { Pisanica }\end{array}$ & $\begin{array}{c}\text { Velika } \\
\text { Pisanica }\end{array}$ & (?) & $\begin{array}{l}24.10 . \\
1916 .\end{array}$ & $\begin{array}{c}13 \text { tabla } \\
4 \text { red } \\
\text { br. } 1288\end{array}$ & Počasni grob \\
\hline 66 & 1285 & $\begin{array}{c}\text { Vitković Mirko } \\
\text { husar novak }\end{array}$ & $\begin{array}{l}18 \text { god. } \\
\text { neoženjen } \\
\text { Varaždin }\end{array}$ & Varaždin & (?) & $\begin{array}{l}28.5 . \\
1916 .\end{array}$ & $\begin{array}{c}15 \text { tabla } \\
4 \text { red } \\
\text { br. } 1285\end{array}$ & $\begin{array}{l}\text { Vojnički } \\
\text { grob. } \\
\text { Isti upis } \\
\text { u: Knjiga } \\
\text { mrtvacah } \\
\text { občenitih } \\
\text { grobova } \\
\text { 1902., } \\
\text { red. br. } 127 \\
\end{array}$ \\
\hline 67 & 1279 & $\begin{array}{c}\text { Korpar Mato } \\
\text { husar } \\
\text { domobran }\end{array}$ & $\begin{array}{l}34 \text { god. } \\
\text { oženjen } \\
\text { Selnik }\end{array}$ & $\begin{array}{l}\text { Selnik } \\
\text { Ivanec }\end{array}$ & (?) & $\begin{array}{l}27.5 . \\
1916 .\end{array}$ & $\begin{array}{c}15 \text { tabla } \\
4 \text { red } \\
\text { br. } 1279\end{array}$ & $\begin{array}{l}\text { Vojnički } \\
\text { grob. } \\
\text { Isti upis } \\
\text { u: Knjiga } \\
\text { mrtvacah } \\
\text { občenitih } \\
\text { grobova } \\
\text { 1902., } \\
\text { red. br. } 124\end{array}$ \\
\hline
\end{tabular}




\begin{tabular}{|c|c|c|c|c|c|c|c|c|}
\hline $\begin{array}{l}\text { Red. } \\
\text { broj }\end{array}$ & $\begin{array}{c}\text { Broj } \\
\text { groba }\end{array}$ & $\begin{array}{l}\text { Ime, prezime } \\
\text { i zanimanje }\end{array}$ & $\begin{array}{l}\text { doba, stališ } \\
\text { i rodno } \\
\text { mjesto }\end{array}$ & $\begin{array}{c}\text { mjesto } \\
\text { obitavanja }\end{array}$ & $\begin{array}{c}\text { posljednja } \\
\text { bolest } \\
\text { s koje je umro }\end{array}$ & $\begin{array}{c}\text { dan i } \\
\text { godina } \\
\text { kada je } \\
\text { sahranjen }\end{array}$ & Opazka & $\begin{array}{l}\text { Napomena } \\
\text { autora }\end{array}$ \\
\hline 68 & 68 & $\begin{array}{c}\text { Rašan Pavao } \\
\text { husar } \\
\text { poljodjelac }\end{array}$ & $\begin{array}{c}26 \text { god. } \\
\text { neoženjen } \\
\text { Djelekovac }\end{array}$ & Djelekovac & Tuberkuloza & $\begin{array}{l}30.4 . \\
1916 .\end{array}$ & $\begin{array}{c}13 \text { tabla } \\
7 \text { red } \\
\text { br. } 68\end{array}$ & $\begin{array}{l}\text { Počasni } \\
\text { grob. } \\
\text { Isti upis u: } \\
\text { 345. Knjiga } \\
\text { mrtvacah } \\
\text { obiteljskih } \\
\text { grobnica } \\
\text { 1902.-1919., } \\
\text { red. br. } 146 \\
\end{array}$ \\
\hline 69 & 64 & $\begin{array}{l}\text { Bogdan Gjuro } \\
\text { (?) 10. dom. } \\
\text { hus. pukovnije }\end{array}$ & $\begin{array}{l}30 \text { god. } \\
\text { oženjen } \\
\text { Ruma }\end{array}$ & Varaždin & Objesio se & $\begin{array}{l}14.3 . \\
1916 .\end{array}$ & $\begin{array}{c}13 \text { tabla } \\
3 \text { red } \\
\text { br. } 64\end{array}$ & $\begin{array}{l}\text { Počasni } \\
\text { grob. } \\
\text { Isti upis u: } \\
\text { 345. Knjiga } \\
\text { mrtvacah } \\
\text { obiteljskih } \\
\text { grobnica } \\
\text { 1902.-1919., } \\
\text { red. br. } 442 \\
\end{array}$ \\
\hline 70 & 321 & Sava Radivoj & $\begin{array}{l}31 \text { god. } \\
\text { oženjen } \\
\text { Nuglaš(ica) } \\
\text { Livno }\end{array}$ & $\begin{array}{l}\text { Nuglaš(ica) } \\
\text { Livno } \\
\text { Bosna }\end{array}$ & Edem glotidis & 8. 7. 1918. & $\begin{array}{c}13 \text { tabla } \\
1 \text { red } \\
\text { br. } 321\end{array}$ & $\begin{array}{l}\text { Počasni } \\
\text { grob. } \\
\text { Isti upis u: } \\
\text { 345. Knjiga } \\
\text { mrtvacah } \\
\text { obiteljskih } \\
\text { grobnica } \\
\text { 1902.-1919., } \\
\text { red. br. } 386\end{array}$ \\
\hline 71 & 329 & $\begin{array}{l}\text { Anton Lesar } \\
\text { vojnik }\end{array}$ & $\begin{array}{c}33 \text { god. } \\
\text { oženjen } \\
\text { Vinicabereg }\end{array}$ & $\begin{array}{l}\text { Vinicabreg } \\
\text { Varaždin }\end{array}$ & Tuberkuloza & 6. 8. 1918. & $\begin{array}{l}13 \text { tabla } \\
1 \text { red } \\
\text { br. } 329\end{array}$ & $\begin{array}{l}\text { Počasni } \\
\text { grob. } \\
\text { Isti upis u: } \\
\text { 345. Knjiga } \\
\text { mrtvacah } \\
\text { obiteljskih } \\
\text { grobnica } \\
\text { 1902.-1919., } \\
\text { red. br. } 397 \\
\end{array}$ \\
\hline 72 & 327 & $\begin{array}{l}\text { Grgelec Balto } \\
\text { vojnik }\end{array}$ & $\begin{array}{c}19 \text { god. } \\
\text { neož } \\
\text { Budrovac }\end{array}$ & $\begin{array}{l}\text { Budrovac } \\
\text { Gjurgjevac }\end{array}$ & Tuberkuloza & 5. 8. 1918. & $\begin{array}{c}13 \text { tabla } \\
1 \text { red } \\
\text { br. } 327\end{array}$ & $\begin{array}{l}\text { Počasni } \\
\text { grob }\end{array}$ \\
\hline 73 & 330 & $\begin{array}{l}\text { Kolaković } \\
\text { Mehmed } \\
\text { vojnik }\end{array}$ & $\begin{array}{c}20 \text { god. } \\
\text { neoženjen } \\
\text { Oršac } \\
\text { Petrovac } \\
\text { Bosna }\end{array}$ & $\begin{array}{c}\text { Oršac } \\
\text { Petrovac } \\
\text { Bosna }\end{array}$ & Rubeola & $\begin{array}{l}15.8 . \\
1918 .\end{array}$ & $\begin{array}{c}13 \text { tabla } \\
7 \text { red } \\
\text { br. } 330\end{array}$ & $\begin{array}{l}\text { Počasni } \\
\text { grob. } \\
\text { Isti upis u: } \\
\text { 345. Knjiga } \\
\text { mrtvacah } \\
\text { obiteljskih } \\
\text { grobnica } \\
\text { 1902.-1919., } \\
\text { red. br. } 397\end{array}$ \\
\hline
\end{tabular}




\begin{tabular}{|c|c|c|c|c|c|c|c|c|}
\hline $\begin{array}{l}\text { Red. } \\
\text { broj }\end{array}$ & \begin{tabular}{|c|} 
Broj \\
groba
\end{tabular} & $\begin{array}{l}\text { Ime, prezime } \\
\text { i zanimanje }\end{array}$ & $\begin{array}{l}\text { doba, stališ } \\
\text { i rodno } \\
\text { mjesto }\end{array}$ & $\begin{array}{c}\text { mjesto } \\
\text { obitavanja }\end{array}$ & $\begin{array}{c}\text { posljednja } \\
\text { bolest } \\
\text { s koje je umro }\end{array}$ & $\begin{array}{c}\text { dan i } \\
\text { godina } \\
\text { kada je } \\
\text { sahranjen }\end{array}$ & Opazka & $\begin{array}{l}\text { Napomena } \\
\text { autora }\end{array}$ \\
\hline 74 & 326 & $\begin{array}{l}\text { Ivan Belčec } \\
\text { vojnik }\end{array}$ & $\begin{array}{l}33 \text { god. } \\
\text { oženjen } \\
\text { Jarek } \\
\text { Trgovišće }\end{array}$ & $\begin{array}{l}\text { Jarek } \\
\text { Trgovišće } \\
\text { Zlatar }\end{array}$ & (?) & $\begin{array}{l}11.8 . \\
1918 .\end{array}$ & $\begin{array}{c}13 \text { tabla } \\
7 \text { red } \\
\text { br. } 326\end{array}$ & $\begin{array}{l}\text { Počasni } \\
\text { grob }\end{array}$ \\
\hline 75 & 309 & $\begin{array}{c}\text { Pavao } \\
\text { Tumbri(?) } \\
\text { (?) vojnik }\end{array}$ & $\begin{array}{c}34 \text { god. } \\
\text { oženjen } \\
\text { Kraljevac }\end{array}$ & $\begin{array}{c}\text { Kraljevac } \\
\text { Pisarovina } \\
\text { Hrvatska }\end{array}$ & (?) & $\begin{array}{l}24.6 . \\
1918 .\end{array}$ & $\begin{array}{c}13 \text { tabla } \\
7 \text { red } \\
\text { br. } 309\end{array}$ & $\begin{array}{c}\text { Počasni } \\
\text { grob. } \\
\text { Isti upis u: } \\
\text { 345. Knjiga } \\
\text { mrtvacah } \\
\text { obiteljskih } \\
\text { grobnica } \\
\text { 1902.-1919., } \\
\text { red. br. } 373\end{array}$ \\
\hline 76 & 308 & $\begin{array}{l}\text { Andrija } \\
\text { Kolarek } \\
\text { vojnik }\end{array}$ & $\begin{array}{c}32 \text { god. } \\
\text { oženjen } \\
\text { Klenovnik }\end{array}$ & Varaždin & Upala pluća & $\begin{array}{l}23.6 . \\
1918 .\end{array}$ & $\begin{array}{c}13 \text { tabla } \\
7 \text { red } \\
\text { br. } 308\end{array}$ & $\begin{array}{c}\text { Počasni } \\
\text { grob. } \\
\text { Isti upis u: } \\
\text { 345. Knjiga } \\
\text { mrtvacah } \\
\text { obiteljskih } \\
\text { grobnica } \\
\text { 1902.-1919., } \\
\text { red. br. } 372\end{array}$ \\
\hline 77 & 307 & $\begin{array}{c}\text { Petar Pjevač } \\
\text { vojnik }\end{array}$ & $\begin{array}{l}20 \text { god. } \\
\text { neoženjen } \\
\text { Čitluk } \\
\text { Gospić }\end{array}$ & $\begin{array}{l}\text { Čitluk } \\
\text { Gospić }\end{array}$ & Upala pluća & 2. 4. 1918 . & $\begin{array}{c}13 \text { tabla } \\
7 \text { red } \\
\text { br. } 307\end{array}$ & $\begin{array}{c}\text { Počasni } \\
\text { grob. } \\
\text { Isti upis u: } \\
\text { 345. Knjiga } \\
\text { mrtvacah } \\
\text { obiteljskih } \\
\text { grobnica } \\
\text { 1902.-1919., } \\
\text { red. br. } 368\end{array}$ \\
\hline 78 & 304 & $\begin{array}{c}\text { Petar Bogović } \\
\text { topnik 7. top. } \\
\text { pukov. }\end{array}$ & $\begin{array}{c}0 \text { god. } \\
\text { neoženjen } \\
\text { Peteranec } \\
\text { kotar } \\
\text { Koprivnica }\end{array}$ & $\begin{array}{l}\text { Peteranec } \\
\text { kotar } \\
\text { Koprivnica }\end{array}$ & $\begin{array}{c}\text { Prostrijelna } \\
\text { rana } \\
\text { na trbuhu }\end{array}$ & $\begin{array}{l}11.5 . \\
1918 .\end{array}$ & $\begin{array}{c}13 \text { tabla } \\
7 \text { red } \\
\text { br. } 304\end{array}$ & $\begin{array}{c}\text { Počasni } \\
\text { grob. Isti } \\
\text { upis u: } \\
\text { 345. Knjiga } \\
\text { mrtvacah } \\
\text { obiteljskih } \\
\text { grobnica } \\
\text { 1902.-1919., } \\
\text { red. br. } 364\end{array}$ \\
\hline 79 & 301 & $\begin{array}{l}\text { Franz Štetter } \\
\text { civil bolničar }\end{array}$ & $\begin{array}{c}41 \text { god. } \\
\text { neoženjen } \\
\text { Varažd. } \\
\text { Toplice }\end{array}$ & Varaždin & Meningitis & 4. 5. 1918. & $\begin{array}{c}13 \text { tabla } \\
7 \text { red } \\
\text { br. } 301\end{array}$ & $\begin{array}{l}\text { Počasni } \\
\text { grob }\end{array}$ \\
\hline 80 & 302 & $\begin{array}{c}\text { Franjo } \\
\text { Bradačić } \\
\text { husar }\end{array}$ & $\begin{array}{l}43 \text { god. } \\
\text { oženjen } \\
\text { Otočac }\end{array}$ & $\begin{array}{l}\text { Varaždin } \\
\text { Zagreb. } \\
\text { cesta br. } 5 .\end{array}$ & Bolest srca & 4.5. 1918. & $\begin{array}{c}13 \text { tabla } \\
7 \text { red } \\
\text { br. } 302\end{array}$ & $\begin{array}{c}\text { Počasni } \\
\text { grob }\end{array}$ \\
\hline
\end{tabular}




\begin{tabular}{|c|c|c|c|c|c|c|c|c|}
\hline $\begin{array}{l}\text { Red. } \\
\text { broj }\end{array}$ & $\begin{array}{c}\text { Broj } \\
\text { groba }\end{array}$ & $\begin{array}{l}\text { Ime, prezime } \\
\text { i zanimanje }\end{array}$ & $\begin{array}{l}\text { doba, stališ } \\
\text { i rodno } \\
\text { mjesto }\end{array}$ & $\begin{array}{c}\text { mjesto } \\
\text { obitavanja }\end{array}$ & $\begin{array}{c}\text { posljednja } \\
\text { bolest } \\
\text { s koje je umro }\end{array}$ & $\begin{array}{c}\text { dan i } \\
\text { godina } \\
\text { kada je } \\
\text { sahranjen }\end{array}$ & Opazka & $\begin{array}{c}\text { Napomena } \\
\text { autora }\end{array}$ \\
\hline 81 & 300 & $\begin{array}{l}\text { Priljeva Mile } \\
\text { vojnik pješak }\end{array}$ & $\begin{array}{c}23 \mathrm{~g} \\
\text { neoženjen } \\
\text { Dunčica, } \\
\text { Petrinja }\end{array}$ & Dunčica & Tuberkuloza & $\begin{array}{l}28.4 . \\
1918 .\end{array}$ & $\begin{array}{c}13 \text { tabla } \\
7 \text { red } \\
\text { br. } 300\end{array}$ & $\begin{array}{c}\text { Počasni } \\
\text { grob. Isti } \\
\text { upis u: } \\
\text { 345. Knjiga } \\
\text { mrtvacah } \\
\text { obiteljskih } \\
\text { grobnica } \\
\text { 1902.-1919., } \\
\text { red. br. } 360\end{array}$ \\
\hline 82 & 299 & $\begin{array}{l}\text { Radišević Ilija } \\
\text { vojnik topnik }\end{array}$ & $\begin{array}{l}41 \text { god. } \\
\text { oženjen } \\
\text { Staroselo }\end{array}$ & Staroselo & $\begin{array}{c}\text { Prostrijelna } \\
\text { rana } \\
\text { na trbuhu }\end{array}$ & $\begin{array}{l}21.4 . \\
1918 .\end{array}$ & $\begin{array}{c}13 \text { tabla } \\
7 \text { red } \\
\text { br. } 299\end{array}$ & $\begin{array}{c}\text { Počasni } \\
\text { grob. Isti } \\
\text { upis u: } \\
\text { 345. Knjiga } \\
\text { mrtvacah } \\
\text { obiteljskih } \\
\text { grobnica } \\
\text { 1902.-1919., } \\
\text { red. br. } 358\end{array}$ \\
\hline 83 & 296 & $\begin{array}{l}\text { Prica Mićo } \\
\text { vojnik } \\
\text { poljodjelac }\end{array}$ & $\begin{array}{l}20 \text { god. } \\
\text { neoženjen } \\
\text { (?) }\end{array}$ & Varaždin & Upala pluća & $\begin{array}{l}18.4 . \\
1918 .\end{array}$ & $\begin{array}{c}13 \text { tabla } \\
7 \text { red } \\
\text { br. } 296\end{array}$ & $\begin{array}{c}\text { Počasni } \\
\text { grob. Isti } \\
\text { upis u: } \\
\text { 345. Knjiga } \\
\text { mrtvacah } \\
\text { obiteljskih } \\
\text { grobnica } \\
\text { 1902.-1919., } \\
\text { red. br. } 356 \\
\end{array}$ \\
\hline 84 & 297 & $\begin{array}{l}\text { Tukulja Gjuro } \\
\text { vojnik topnik }\end{array}$ & $\begin{array}{l}35 \text { god. } \\
\text { oženjen } \\
(?)\end{array}$ & $\begin{array}{l}\text { Pričuvna } \\
\text { bolnica III. }\end{array}$ & Epilepsija & $\begin{array}{l}19.4 . \\
1918 .\end{array}$ & $\begin{array}{c}13 \text { tabla } \\
7 \text { red } \\
\text { br. } 297\end{array}$ & $\begin{array}{c}\text { Počasni } \\
\text { grob. Isti } \\
\text { upis u: } \\
\text { 345. Knjiga } \\
\text { mrtvacah } \\
\text { obiteljskih } \\
\text { grobnica } \\
\text { 1902.-1919., } \\
\text { red. br. } 357\end{array}$ \\
\hline 85 & 293 & $\begin{array}{c}\text { Salamon Pavao } \\
\text { glasbar }\end{array}$ & $\begin{array}{l}32 \text { god. } \\
\text { oženjen } \\
\text { Varaždin }\end{array}$ & Varaždin & Tuberkuloza & 7. 4. 1918. & $\begin{array}{l}13 \text { tabla } \\
8 \text { red } \\
\text { br. } 293\end{array}$ & $\begin{array}{l}\text { Počasni } \\
\text { grob }\end{array}$ \\
\hline 86 & 291 & $\begin{array}{c}\text { Koren Jakob } \\
\text { vojnik pješak }\end{array}$ & $\begin{array}{l}51 \text { god. } \\
\text { neoženjen } \\
\text { Preseka }\end{array}$ & Preseka & Upala pluća & $\begin{array}{l}28.3 . \\
1918 .\end{array}$ & $\begin{array}{l}13 \text { tabla } \\
7 \text { red } \\
\text { br. } 291\end{array}$ & $\begin{array}{c}\text { Počasni } \\
\text { grob. Isti } \\
\text { upis u: } \\
\text { 345. Knjiga } \\
\text { mrtvacah } \\
\text { obiteljskih } \\
\text { grobnica } \\
\text { 1902.-1919., } \\
\text { red. br. } 349\end{array}$ \\
\hline
\end{tabular}




\begin{tabular}{|c|c|c|c|c|c|c|c|c|}
\hline $\begin{array}{l}\text { Red. } \\
\text { broj }\end{array}$ & $\begin{array}{l}\text { Broj } \\
\text { groba }\end{array}$ & $\begin{array}{l}\text { Ime, prezime } \\
\text { i zanimanje }\end{array}$ & $\begin{array}{l}\text { doba, stališ } \\
\text { i rodno } \\
\text { mjesto }\end{array}$ & $\begin{array}{c}\text { mjesto } \\
\text { obitavanja }\end{array}$ & $\begin{array}{c}\text { posljednja } \\
\text { bolest } \\
\text { s koje je umro }\end{array}$ & $\begin{array}{c}\text { dan i } \\
\text { godina } \\
\text { kada je } \\
\text { sahranjen }\end{array}$ & Opazka & $\begin{array}{l}\text { Napomena } \\
\text { autora }\end{array}$ \\
\hline 87 & 289 & $\begin{array}{c}\text { Mikulčić Tomo } \\
\text { vojnik pješak }\end{array}$ & $\begin{array}{c}23 \text { god. } \\
\text { neoženjen } \\
\text { Gotalovec }\end{array}$ & Varaždin & Upala & $\begin{array}{l}19.3 . \\
1918 .\end{array}$ & $\begin{array}{c}13 \text { tabla } \\
7 \text { red } \\
\text { br. } 289\end{array}$ & $\begin{array}{l}\text { Počasni } \\
\text { grob }\end{array}$ \\
\hline 88 & 290 & $\begin{array}{c}\text { Novak Josip } \\
\text { vojnik radnik }\end{array}$ & $\begin{array}{c}49 \mathrm{~g} \\
\text { oženjen } \\
(?)\end{array}$ & Via Salica & Upala pluća & $\begin{array}{l}24.3 . \\
1918 .\end{array}$ & $\begin{array}{c}13 \text { tabla } \\
7 \text { red } \\
\text { br. } 290\end{array}$ & $\begin{array}{l}\text { Počasni } \\
\text { grob }\end{array}$ \\
\hline 89 & 285 & $\begin{array}{c}\text { Dragičević } \\
\text { Marko }\end{array}$ & $\begin{array}{l}50 \text { god. } \\
\text { oženjen } \\
\text { Jablanac }\end{array}$ & Fiume & (?) & $\begin{array}{l}10.2 . \\
1918 .\end{array}$ & $\begin{array}{c}13 \text { tabla } \\
4 \text { red } \\
\text { br. } 285\end{array}$ & \begin{tabular}{|c} 
Počasni \\
grob. Isti \\
upis u: \\
345. Knjiga \\
mrtvacah \\
obiteljskih \\
grobnica \\
1902.-1919., \\
red. br. 340
\end{tabular} \\
\hline 90 & 286 & $\begin{array}{c}\text { Mandić Mate } \\
\text { vojnik }\end{array}$ & $\begin{array}{l}45 \text { god. } \\
\text { oženjen } \\
\text { Split }\end{array}$ & Split & Upala pluća & $\begin{array}{l}12.2 . \\
1918 .\end{array}$ & $\begin{array}{c}13 \text { tabla } \\
4 \text { red } \\
\text { br. } 286\end{array}$ & $\begin{array}{l}\text { Počasni } \\
\text { grob. Isti } \\
\text { upis u: } \\
\text { 345. Knjiga } \\
\text { mrtvacah } \\
\text { obiteljskih } \\
\text { grobnica } \\
\text { 1902.-1919., } \\
\text { red. br. } 342\end{array}$ \\
\hline 91 & 288 & $\begin{array}{l}\text { Šprem Antun } \\
\text { vojnik }\end{array}$ & $\begin{array}{l}\text { Bednja } 26 \\
\text { god. } \\
\text { neoženjen }\end{array}$ & Bednja & Velike boginje & $\begin{array}{l}17.2 . \\
1918 .\end{array}$ & $\begin{array}{c}13 \text { tabla } \\
5 \text { red } \\
\text { br. } 288\end{array}$ & $\begin{array}{l}\text { Počasni } \\
\text { grob. Isti } \\
\text { upis u: } \\
\text { 345. Knjiga } \\
\text { mrtvacah } \\
\text { obiteljskih } \\
\text { grobnica } \\
\text { 1902.-1919., } \\
\text { red. br. } 345\end{array}$ \\
\hline 92 & 287 & $\begin{array}{c}\text { Erceg Antun } \\
\text { Joso } \\
\text { vojnik }\end{array}$ & $\begin{array}{l}22 \text { god. } \\
\text { neoženjen } \\
\text { Šibenik } \\
\text { Dalmatia }\end{array}$ & Livno & Tuberkuloza & $\begin{array}{l}17.2 . \\
1918 .\end{array}$ & $\begin{array}{c}13 \text { tabla } \\
5 \text { red } \\
\text { br. } 287\end{array}$ & Počasni grob \\
\hline 93 & 284 & $\begin{array}{l}\text { Jurčević Pavao } \\
\text { vojnik pješak }\end{array}$ & $\begin{array}{c}38 \text { god. } \\
\text { oženjen } \\
(?)\end{array}$ & (?) & $\begin{array}{c}\text { Upala pluća } \\
\text { (?) }\end{array}$ & 1.2. 1918 . & $\begin{array}{c}13 \text { tabla } \\
7 \text { red } \\
\text { br. } 284\end{array}$ & Počasni grob \\
\hline
\end{tabular}




\begin{tabular}{|c|c|c|c|c|c|c|c|c|}
\hline $\begin{array}{l}\text { Red. } \\
\text { broj }\end{array}$ & \begin{tabular}{|c|} 
Broj \\
groba
\end{tabular} & $\begin{array}{l}\text { Ime, prezime } \\
\text { i zanimanje }\end{array}$ & $\begin{array}{l}\text { doba, stališ } \\
\text { i rodno } \\
\text { mjesto }\end{array}$ & $\begin{array}{c}\text { mjesto } \\
\text { obitavanja }\end{array}$ & $\begin{array}{c}\text { posljednja } \\
\text { bolest } \\
\text { s koje je umro }\end{array}$ & $\begin{array}{c}\text { dan i } \\
\text { godina } \\
\text { kada je } \\
\text { sahranjen }\end{array}$ & Opazka & $\begin{array}{l}\text { Napomena } \\
\text { autora }\end{array}$ \\
\hline 94 & 281 & $\begin{array}{l}\text { Milovski Josip } \\
\text { vojnik pješak }\end{array}$ & $\begin{array}{l}21 \text { god. } \\
\text { oženjen } \\
\text { Hrašćina } \\
\text { Trgovišće }\end{array}$ & $\begin{array}{l}\text { Hrašćina } \\
\text { Trgovišće }\end{array}$ & Bolest srca & $\begin{array}{l}21.1 . \\
1918 .\end{array}$ & $\begin{array}{c}13 \text { tabla } \\
4 \text { red } \\
\text { br. } 284\end{array}$ & $\begin{array}{l}\text { Počasni } \\
\text { grob }\end{array}$ \\
\hline 95 & 277 & $\begin{array}{c}\text { Lenerdić Gjuro } \\
\text { vojnik husar }\end{array}$ & $\begin{array}{c}41 \text { god. } \\
\text { oženjen } \\
\text { Mičelinac }\end{array}$ & Šemovec & Tuberkuloza & 15.1 .1918 & $\begin{array}{c}13 \text { tabla } \\
4 \text { red } \\
\text { br. } 277\end{array}$ & $\begin{array}{c}\text { Počasni } \\
\text { grob }\end{array}$ \\
\hline 96 & 276 & $\begin{array}{l}\text { Banalić Šerif } \\
\text { vojnik borac }\end{array}$ & $\begin{array}{l}35 \text { god. } \\
\text { oženjen } \\
\text { Kozarac }\end{array}$ & Kozarac & Tuberkuloza & 9.1.1918. & $\begin{array}{c}13 \text { tabla } \\
4 \text { red } \\
\text { br. } 276\end{array}$ & $\begin{array}{l}\text { Počasni } \\
\text { grob }\end{array}$ \\
\hline 97 & 275 & $\begin{array}{c}\text { Marota Ivan } \\
\text { vojnik pješak }\end{array}$ & $\begin{array}{c}24 \text { god. } \\
\text { oženjen } \\
\text { Caktorunya }\end{array}$ & Caktorunya & Tuberkuloza & 7.1.1918. & $\begin{array}{c}13 \text { tabla } \\
3 \text { red } \\
\text { br. } 275\end{array}$ & $\begin{array}{l}\text { Počasni } \\
\text { grob }\end{array}$ \\
\hline 98 & 273 & $\begin{array}{l}\text { Rašić Ivan } \\
\text { vojnik (?) }\end{array}$ & $\begin{array}{l}38 \text { god. } \\
\text { oženjen } \\
\text { Božinci }\end{array}$ & Božinci & Tuberkuloza & $\begin{array}{l}31.1 . \\
1918 .\end{array}$ & $\begin{array}{c}13 \text { tabla } \\
4 \text { red } \\
\text { br. } 273\end{array}$ & $\begin{array}{l}\text { Počasni } \\
\text { grob }\end{array}$ \\
\hline 99 & 270 & $\begin{array}{l}\text { Ivančić Josip } \\
\text { vojnik pješak }\end{array}$ & $\begin{array}{c}18 \mathrm{~g} \\
\text { neoženjen } \\
\text { Draškovec }\end{array}$ & Draškovec & Gripa & $\begin{array}{l}26.3 . \\
1917 .\end{array}$ & $\begin{array}{c}13 \text { tabla } \\
4 \text { red } \\
\text { br. } 270\end{array}$ & $\begin{array}{l}\text { Počasni } \\
\text { grob }\end{array}$ \\
\hline 100 & 269 & $\begin{array}{l}\text { Špoljarić Ivan } \\
\text { vojnik topnik }\end{array}$ & $\begin{array}{c}26 \text { god. } \\
\text { neoženjen } \\
\text { Jakopovec }\end{array}$ & Jakopovec & $\begin{array}{l}\text { Prostrijelne } \\
\text { rane }\end{array}$ & $\begin{array}{l}17.12 . \\
1917 .\end{array}$ & $\begin{array}{c}13 \text { tabla } \\
3 \text { red } \\
\text { br. } 269\end{array}$ & $\begin{array}{c}\text { Počasni } \\
\text { grob. Isti } \\
\text { upis u: } \\
\text { 345. Knjiga } \\
\text { mrtvacah } \\
\text { obiteljskih } \\
\text { grobnica } \\
\text { 1902.-1919., } \\
\text { red. br. } 329\end{array}$ \\
\hline 101 & 268 & $\begin{array}{c}\text { Tomašković } \\
\text { Mihalj } \\
\text { vojnik pješak }\end{array}$ & $\begin{array}{l}31 \text { god. } \\
\text { oženjen } \\
\text { Jalkovec }\end{array}$ & Jalkovec & $\begin{array}{l}\text { Prostrijelne } \\
\text { rane/ } \\
\text { gangrena }\end{array}$ & $\begin{array}{l}7.12 . \\
1917 .\end{array}$ & $\begin{array}{c}13 \text { tabla } \\
3 \text { red } \\
\text { br. } 268\end{array}$ & $\begin{array}{l}\text { Počasni } \\
\text { grob }\end{array}$ \\
\hline 102 & 267 & $\begin{array}{c}\text { Čićek } \\
\text { Lepoglavec } \\
\text { Fabijan } \\
\text { vojnik (?) }\end{array}$ & $\begin{array}{l}45 \text { god. } \\
\text { Vrhovec }\end{array}$ & Vrhovec & $\begin{array}{l}\text { Upala pluća } \\
\text { (?) }\end{array}$ & $\begin{array}{l}5.12 . \\
1917 .\end{array}$ & $\begin{array}{c}13 \text { tabla } \\
2 \text { red } \\
\text { br. } 267\end{array}$ & $\begin{array}{l}\text { Počasni } \\
\text { grob }\end{array}$ \\
\hline
\end{tabular}




\begin{tabular}{|c|c|c|c|c|c|c|c|c|}
\hline $\begin{array}{l}\text { Red. } \\
\text { broj }\end{array}$ & \begin{tabular}{|c|} 
Broj \\
groba
\end{tabular} & $\begin{array}{l}\text { Ime, prezime } \\
\text { i zanimanje }\end{array}$ & $\begin{array}{l}\text { doba, stališ } \\
\text { i rodno } \\
\text { mjesto }\end{array}$ & $\begin{array}{c}\text { mjesto } \\
\text { obitavanja }\end{array}$ & $\begin{array}{c}\text { posljednja } \\
\text { bolest } \\
\text { s koje je umro }\end{array}$ & $\begin{array}{c}\text { dan i } \\
\text { godina } \\
\text { kada je } \\
\text { sahranjen }\end{array}$ & Opazka & $\begin{array}{l}\text { Napomena } \\
\text { autora }\end{array}$ \\
\hline 103 & 263 & $\begin{array}{c}\text { Kujundžić } \\
\text { Nikola } \\
\text { vojnik pješak }\end{array}$ & $\begin{array}{c}41 \text { god. } \\
\text { neoženjen } \\
\text { Višnjik }\end{array}$ & Višnjik & $\begin{array}{l}\text { Prostrijelne } \\
\text { rane (?) }\end{array}$ & $\begin{array}{l}10.11 . \\
1917 .\end{array}$ & $\begin{array}{c}13 \text { tabla } \\
2 \text { red } \\
\text { br. } 263\end{array}$ & $\begin{array}{c}\text { Počasni } \\
\text { grob. Isti } \\
\text { upis u: } \\
\text { 345. Knjiga } \\
\text { mrtvacah } \\
\text { obiteljskih } \\
\text { grobnica } \\
\text { 1902.-1919., } \\
\text { red. br. } 318\end{array}$ \\
\hline 104 & 260 & $\begin{array}{l}\text { Križanić Jakob } \\
\text { vojnik topnik }\end{array}$ & $\begin{array}{l}34 \text { god. } \\
\text { oženjen } \\
\text { Sračinec }\end{array}$ & Sračinec & $\begin{array}{c}\text { Upala pluća } \\
\text { (?) }\end{array}$ & $\begin{array}{l}28.10 . \\
1917 .\end{array}$ & $\begin{array}{l}13 \text { tabla } \\
2 \text { red } \\
\text { br. } 260\end{array}$ & $\begin{array}{c}\text { Počasni } \\
\text { grob. Isti } \\
\text { upis u: } \\
\text { 345. Knjiga } \\
\text { mrtvacah } \\
\text { obiteljskih } \\
\text { grobnica } \\
\text { 1902.-1919., } \\
\text { red. br. } 316\end{array}$ \\
\hline 105 & 258 & $\begin{array}{c}\text { Belačić Ivo } \\
\text { vojnik topnik }\end{array}$ & $\begin{array}{l}18 \text { god. } \\
\text { neoženjen } \\
\text { Slatina }\end{array}$ & Slatina & Tuberkuloza & $\begin{array}{l}19.10 . \\
1917 .\end{array}$ & $\begin{array}{c}13 \text { tabla } \\
1 \text { red } \\
\text { br. } 258\end{array}$ & $\begin{array}{c}\text { Počasni } \\
\text { grob. Isti } \\
\text { upis u: } \\
\text { 345. Knjiga } \\
\text { mrtvacah } \\
\text { obiteljskih } \\
\text { grobnica } \\
\text { 1902.-1919. } \\
\text { red. br. } 313\end{array}$ \\
\hline 106 & 257 & $\begin{array}{l}\text { Vujević Gjuro } \\
\text { vojnik strijelac }\end{array}$ & $\begin{array}{c}20 \text { god. } \\
\text { neoženjen } \\
\text { Kastelnovo }\end{array}$ & Kastelnovo & $\begin{array}{c}\text { Povreda } \\
\text { kralježnice (?) }\end{array}$ & $\begin{array}{l}17.10 . \\
1917 .\end{array}$ & $\begin{array}{l}13 \text { tabla } \\
1 \text { red } \\
\text { br. } 257\end{array}$ & \begin{tabular}{|c|} 
Počasni \\
grob. Isti \\
upis u: \\
345. Knjiga \\
mrtvacah \\
obiteljskih \\
grobnica \\
1902.-1919. \\
red. br. 311
\end{tabular} \\
\hline 107 & 237 & $\begin{array}{c}\text { Vinković Mate } \\
\text { (?) Luka } \\
\text { vojnik pješak }\end{array}$ & $\begin{array}{c}3 \text { god. } \\
\text { oženjen } \\
\text { Dragljena }\end{array}$ & (?) & (?) & $\begin{array}{l}14.9 . \\
1917 .\end{array}$ & $\begin{array}{l}13 \text { tabla } \\
8 \text { red } \\
\text { br. } 237\end{array}$ & $\begin{array}{c}\text { Počasni } \\
\text { grob. Isti } \\
\text { upis u: } \\
\text { 345. Knjiga } \\
\text { mrtvacah } \\
\text { obiteljskih } \\
\text { grobnica } \\
\text { 1902.-1919. } \\
\text { red. br. } 284\end{array}$ \\
\hline 108 & 238 & $\begin{array}{l}\text { Gregorić Milan } \\
\text { (?) Josip } \\
\text { vojnik pješak }\end{array}$ & $\begin{array}{l}47 \text { god. } \\
\text { oženjen } \\
\text { Lobor }\end{array}$ & Varaždin & Tuberkuloza & $\begin{array}{l}14.9 . \\
1917 .\end{array}$ & $\begin{array}{c}13 \text { tabla } \\
8 \text { red } \\
\text { br. } 238\end{array}$ & $\begin{array}{c}\text { Isti upis u: } \\
\text { 345. Knjiga } \\
\text { mrtvacah } \\
\text { obiteljskih } \\
\text { grobnica } \\
\text { 1902.-1919. } \\
\text { red. br. } 285\end{array}$ \\
\hline
\end{tabular}




\begin{tabular}{|c|c|c|c|c|c|c|c|c|}
\hline $\begin{array}{l}\text { Red. } \\
\text { broj }\end{array}$ & $\begin{array}{c}\text { Broj } \\
\text { groba }\end{array}$ & $\begin{array}{l}\text { Ime, prezime } \\
\text { i zanimanje }\end{array}$ & $\begin{array}{l}\text { doba, stališ } \\
\text { i rodno } \\
\text { mjesto }\end{array}$ & $\begin{array}{c}\text { mjesto } \\
\text { obitavanja }\end{array}$ & $\begin{array}{c}\text { posljednja } \\
\text { bolest } \\
\text { s koje je umro }\end{array}$ & $\begin{array}{c}\text { dan i } \\
\text { godina } \\
\text { kada je } \\
\text { sahranjen }\end{array}$ & Opazka & $\begin{array}{l}\text { Napomena } \\
\text { autora }\end{array}$ \\
\hline 109 & 256 & $\begin{array}{c}\text { Vi(?)ašek } \\
\text { vojnik, topnik }\end{array}$ & $\begin{array}{c}19 \text { god. } \\
\text { neoženjen } \\
\text { Ježovec }\end{array}$ & Ježovec & Bolest srca & $\begin{array}{l}11.10 . \\
1917 .\end{array}$ & $\begin{array}{c}13 \text { tabla } \\
1 \text { red } \\
\text { br. } 256\end{array}$ & $\begin{array}{l}\text { Počasni } \\
\text { grob. Isti } \\
\text { upis u: } \\
\text { 345. Knjiga } \\
\text { mrtvacah } \\
\text { obiteljskih } \\
\text { grobnica } \\
\text { 1902.-1919., } \\
\text { red. br. } 309\end{array}$ \\
\hline 110 & 250 & $\begin{array}{c}\text { (?) } \\
\text { vojnik pješak }\end{array}$ & $\begin{array}{c}32 \text { god. } \\
\text { oženjen } \\
\text { Garačić(?) }\end{array}$ & Garačić(?) & (?) & $\begin{array}{l}1.10 . \\
1917 .\end{array}$ & $\begin{array}{l}13 \text { tabla } \\
3 \text { red } \\
\text { br. } 250\end{array}$ & $\begin{array}{l}\text { Počasni } \\
\text { grob }\end{array}$ \\
\hline 111 & 252 & $\begin{array}{l}\text { (?) Grčić Imbro } \\
\text { vojnik topnik }\end{array}$ & $\begin{array}{c}18 \text { god. } \\
\text { neoženjen } \\
\text { Veleškovec }\end{array}$ & Veleškovec & Bolest srca & $\begin{array}{l}3.10 . \\
1917 .\end{array}$ & $\begin{array}{l}13 \text { tabla } \\
1 \text { red } \\
\text { br. } 252\end{array}$ & $\begin{array}{c}\text { Počasni } \\
\text { grob. Isti } \\
\text { upis u: } \\
\text { 345. Knjiga } \\
\text { mrtvacah } \\
\text { obiteljskih } \\
\text { grobnica } \\
\text { 1902.-1919., } \\
\text { red. br. } 303 \\
\end{array}$ \\
\hline 112 & 245 & $\begin{array}{l}\text { Andjić Andrija } \\
\text { vojnik topnik }\end{array}$ & $\begin{array}{l}23 \text { god. } \\
\text { neoženjen } \\
\text { Tordinci } \\
\text { Vukovar }\end{array}$ & $\begin{array}{l}\text { Pričuvna } \\
\text { bolnica III. }\end{array}$ & Bolest srca & $\begin{array}{l}23.9 . \\
1917 .\end{array}$ & $\begin{array}{c}13 \text { tabla } \\
8 \text { red } \\
\text { br. } 245\end{array}$ & $\begin{array}{l}\text { Počasni } \\
\text { grob. Isti } \\
\text { upis u: } \\
\text { 345. Knjiga } \\
\text { mrtvacah } \\
\text { obiteljskih } \\
\text { grobnica } \\
\text { 1902.-1919., } \\
\text { red. br. } 292\end{array}$ \\
\hline 113 & 244 & $\begin{array}{c}\text { Potočnik } \\
\text { Matija } \\
\text { vojnik pješak }\end{array}$ & $\begin{array}{l}37 \text { god. } \\
\text { neoženjen } \\
\text { (?)berg }\end{array}$ & $\begin{array}{c}\text { Prassber } \\
\text { Cilli }\end{array}$ & Bolest srca & $\begin{array}{l}22.9 . \\
1917 .\end{array}$ & $\begin{array}{c}13 \text { tabla } \\
8 \text { red } \\
\text { br. } 244\end{array}$ & $\begin{array}{l}\text { Počasni } \\
\text { grob. Isti } \\
\text { upis u: } \\
\text { 345. Knjiga } \\
\text { mrtvacah } \\
\text { obiteljskih } \\
\text { grobnica } \\
\text { 1902.-1919., } \\
\text { red. br. } 291\end{array}$ \\
\hline 114 & 239 & $\begin{array}{l}\text { Šmiel Johann } \\
\text { vojnik pješak }\end{array}$ & $\begin{array}{l}21 \text { god. } \\
\text { neoženjen } \\
\text { Pertinja }\end{array}$ & (?) & (?) & $\begin{array}{l}15.9 . \\
1917 .\end{array}$ & $\begin{array}{c}13 \text { tabla } \\
8 \text { red } \\
\text { br. } 239\end{array}$ & Počasni grob \\
\hline
\end{tabular}




\begin{tabular}{|c|c|c|c|c|c|c|c|c|}
\hline $\begin{array}{l}\text { Red. } \\
\text { broj }\end{array}$ & $\begin{array}{c}\text { Broj } \\
\text { groba }\end{array}$ & $\begin{array}{l}\text { Ime, prezime } \\
\text { i zanimanje }\end{array}$ & $\begin{array}{l}\text { doba, stališ } \\
\text { i rodno } \\
\text { mjesto }\end{array}$ & $\begin{array}{c}\text { mjesto } \\
\text { obitavanja }\end{array}$ & $\begin{array}{c}\text { posljednja } \\
\text { bolest } \\
\text { s koje je umro }\end{array}$ & $\begin{array}{c}\text { dan i } \\
\text { godina } \\
\text { kada je } \\
\text { sahranjen }\end{array}$ & Opazka & $\begin{array}{l}\text { Napomena } \\
\text { autora }\end{array}$ \\
\hline 115 & 235 & $\begin{array}{c}\text { Bešenić Ivan } \\
\text { vojnik (?) }\end{array}$ & $\begin{array}{c}40 \text { god. } \\
\text { neoženjen } \\
\text { Hrastovec }\end{array}$ & Hrastovec & Upala pluća & $\begin{array}{l}12.9 . \\
1917 .\end{array}$ & $\begin{array}{c}13 \text { tabla } \\
8 \text { red } \\
\text { br. } 235\end{array}$ & $\begin{array}{l}\text { Počasni } \\
\text { grob. Isti } \\
\text { upis u: } \\
\text { 345. Knjiga } \\
\text { mrtvacah } \\
\text { obiteljskih } \\
\text { grobnica } \\
\text { 1902.-1919., } \\
\text { red. br. 282 }\end{array}$ \\
\hline 116 & 226 & $\begin{array}{l}\text { Miščin Jakob } \\
\text { vojnik krojač }\end{array}$ & $\begin{array}{l}38 \text { god. } \\
\text { oženjen } \\
\text { Varaždin }\end{array}$ & Varaždin & Upala pluća & 4.9. 1917. & $\begin{array}{c}13 \text { tabla } \\
8 \text { red } \\
\text { br. } 226\end{array}$ & $\begin{array}{l}\text { Počasni } \\
\text { grob. Isti } \\
\text { upis u: } \\
\text { 345. Knjiga } \\
\text { mrtvacah } \\
\text { obiteljskih } \\
\text { grobnica } \\
\text { 1902.-1919., } \\
\text { red. br. } 272\end{array}$ \\
\hline 117 & 227 & $\begin{array}{l}\text { Šipek Franjo } \\
\text { vojnik topnik }\end{array}$ & $\begin{array}{c}18 \mathrm{~g} \\
\text { neoženjen } \\
\text { Martinci }\end{array}$ & Martinci & Bolest srca & 4.9. 1917. & $\begin{array}{c}13 \text { tabla } \\
8 \text { red } \\
\text { br. } 227\end{array}$ & $\begin{array}{l}\text { Počasni } \\
\text { grob. Isti } \\
\text { upis u: } \\
\text { 345. Knjiga } \\
\text { mrtvacah } \\
\text { obiteljskih } \\
\text { grobnica } \\
\text { 1902.-1919., } \\
\text { red. br. } 273\end{array}$ \\
\hline 118 & 228 & $\begin{array}{c}\text { Šarić Bariša } \\
\text { vojnik pješak }\end{array}$ & $\begin{array}{c}21 \text { god. } \\
\text { neoženjen } \\
(?)\end{array}$ & (?) & Gangrena & 5.9.1917. & $\begin{array}{c}13 \text { tabla } \\
8 \text { red } \\
\text { br. } 228\end{array}$ & \begin{tabular}{|c|} 
Počasni \\
grob. Isti \\
upis u: \\
345. Knjiga \\
mrtvacah \\
obiteljskih \\
grobnica \\
1902.-1919., \\
red. br. 274 \\
\end{tabular} \\
\hline 119 & 229 & $\begin{array}{c}\text { Magjarić } \\
\text { Nikola } \\
\text { vojnik pješak }\end{array}$ & $\begin{array}{c}42 \text { god. } \\
\text { oženjen } \\
\text { Leštakovec }\end{array}$ & Leštakovec & (?) & $\begin{array}{l}10.9 . \\
1917 .\end{array}$ & $\begin{array}{c}13 \text { tabla } \\
8 \text { red } \\
\text { br. } 229\end{array}$ & \begin{tabular}{|c|} 
Počasni \\
grob. Isti \\
upis u: \\
345. Knjiga \\
mrtvacah \\
obiteljskih \\
grobnica \\
1902.-1919., \\
red. br. 275
\end{tabular} \\
\hline
\end{tabular}




\begin{tabular}{|c|c|c|c|c|c|c|c|c|}
\hline $\begin{array}{l}\text { Red. } \\
\text { broj }\end{array}$ & \begin{tabular}{|c|} 
Broj \\
groba
\end{tabular} & $\begin{array}{l}\text { Ime, prezime } \\
\text { i zanimanje }\end{array}$ & $\begin{array}{l}\text { doba, stališ } \\
\text { i rodno } \\
\text { mjesto }\end{array}$ & $\begin{array}{c}\text { mjesto } \\
\text { obitavanja }\end{array}$ & $\begin{array}{c}\text { posljednja } \\
\text { bolest } \\
\text { s koje je umro }\end{array}$ & $\begin{array}{c}\text { dan i } \\
\text { godina } \\
\text { kada je } \\
\text { sahranjen }\end{array}$ & Opazka & $\begin{array}{l}\text { Napomena } \\
\text { autora }\end{array}$ \\
\hline 120 & 232 & $\begin{array}{c}\text { Konjundžić } \\
\text { Mate } \\
\text { vojnik strijelac }\end{array}$ & $\begin{array}{c}41 \text { god. } \\
\text { oženjen } \\
\text { Podbablje }\end{array}$ & Podbablje & Tetanus & $\begin{array}{l}10.9 . \\
1917 .\end{array}$ & $\begin{array}{c}13 \text { tabla } \\
8 \text { red } \\
\text { br. } 232\end{array}$ & $\begin{array}{l}\text { Počasni } \\
\text { grob. Isti } \\
\text { upis u: } \\
\text { 345. Knjiga } \\
\text { mrtvacah } \\
\text { obiteljskih } \\
\text { grobnica } \\
\text { 1902.-1919., } \\
\text { red. br. } 279\end{array}$ \\
\hline 121 & 224 & $\begin{array}{l}\text { Mališ Simon } \\
\text { vojnik topnik }\end{array}$ & $\begin{array}{l}35 \text { god. } \\
\text { oženjen } \\
(?)\end{array}$ & $\begin{array}{l}\text { Pričuvna } \\
\text { bolnica III. }\end{array}$ & Tuberkuloza & $\begin{array}{l}28.8 . \\
1917 .\end{array}$ & $\begin{array}{c}13 \text { tabla } \\
8 \text { red } \\
\text { br. } 224\end{array}$ & $\begin{array}{l}\text { Počasni } \\
\text { grob. Isti } \\
\text { upis u: } \\
\text { 345. Knjiga } \\
\text { mrtvacah } \\
\text { obiteljskih } \\
\text { grobnica } \\
\text { 1902.-1919., } \\
\text { red. br. } 270 \\
\end{array}$ \\
\hline 122 & 222 & $\begin{array}{l}\text { Fiolić Tomo } \\
\text { topnik }\end{array}$ & $\begin{array}{c}25 \text { god. } \\
\text { neoženjen } \\
\text { Dubrava }\end{array}$ & Dubrava & $\begin{array}{c}\text { Bolesti } \\
\text { bubrega }\end{array}$ & $\begin{array}{l}23.8 . \\
1917 .\end{array}$ & $\begin{array}{c}13 \text { tabla } \\
8 \text { red } \\
\text { br. } 222\end{array}$ & $\begin{array}{l}\text { Počasni } \\
\text { grob. Isti } \\
\text { upis u: } \\
\text { 345. Knjiga } \\
\text { mrtvacah } \\
\text { obiteljskih } \\
\text { grobnica } \\
\text { 1902.-1919., } \\
\text { red. br. } 267\end{array}$ \\
\hline 123 & 215 & $\begin{array}{l}\text { Paško Serezlija } \\
\text { vojnik pješak }\end{array}$ & $\begin{array}{c}1897 ., \\
\text { oženjen } \\
\text { Čavoglavi } \\
\text { Knin } \\
\text { Dalmatia }\end{array}$ & $\begin{array}{l}\text { Pričuvna } \\
\text { bolnica III. }\end{array}$ & Upala pluća & $\begin{array}{l}25.6 . \\
1917 .\end{array}$ & $\begin{array}{c}13 \text { tabla } \\
8 \text { red } \\
\text { br. } 215\end{array}$ & $\begin{array}{c}\text { Počasni } \\
\text { grob. Isti } \\
\text { upis u: } \\
\text { 345. Knjiga } \\
\text { mrtvacah } \\
\text { obiteljskih } \\
\text { grobnica } \\
\text { 1902.-1919., } \\
\text { red. br. 239 } \\
\end{array}$ \\
\hline 124 & 214 & $\begin{array}{l}\text { Demić Dušan } \\
\text { vojnik pješak }\end{array}$ & $\begin{array}{l}\text { oženjen } \\
\text { Baneš }\end{array}$ & Baneš & Bolest želuca & $\begin{array}{l}24.6 . \\
1917 .\end{array}$ & $\begin{array}{c}13 \text { tabla } \\
8 \text { red } \\
\text { br. } 214\end{array}$ & $\begin{array}{l}\text { Počasni } \\
\text { grob }\end{array}$ \\
\hline 125 & 208 & $\begin{array}{l}\text { Kuzma Nikola } \\
\text { vojnik pješak }\end{array}$ & (?) & (?) & Tetanus & $\begin{array}{l}16.6 . \\
1917 .\end{array}$ & $\begin{array}{c}13 \text { tabla } \\
8 \text { red } \\
\text { br. } 208\end{array}$ & $\begin{array}{l}\text { Počasni } \\
\text { grob }\end{array}$ \\
\hline
\end{tabular}




\begin{tabular}{|c|c|c|c|c|c|c|c|c|}
\hline $\begin{array}{l}\text { Red. } \\
\text { broj }\end{array}$ & \begin{tabular}{|c|} 
Broj \\
groba
\end{tabular} & $\begin{array}{l}\text { Ime, prezime } \\
\text { i zanimanje }\end{array}$ & $\begin{array}{l}\text { doba, stališ } \\
\text { i rodno } \\
\text { mjesto }\end{array}$ & $\begin{array}{c}\text { mjesto } \\
\text { obitavanja }\end{array}$ & $\begin{array}{c}\text { posljednja } \\
\text { bolest } \\
\text { s koje je umro }\end{array}$ & $\begin{array}{c}\text { dan i } \\
\text { godina } \\
\text { kada je } \\
\text { sahranjen }\end{array}$ & Opazka & $\begin{array}{l}\text { Napomena } \\
\text { autora }\end{array}$ \\
\hline 126 & 205 & $\begin{array}{c}\text { Petrić Sava } \\
\text { vojnik topnik }\end{array}$ & $\begin{array}{l}18 \text { god. } \\
\text { neoženjen } \\
\text { Prijedor }\end{array}$ & Prijedor & Bolest želuca & 1.6. 1917. & $\begin{array}{l}13 \text { tabla } \\
3 \text { red } \\
\text { br. } 205\end{array}$ & $\begin{array}{l}\text { Počasni } \\
\text { grob. Isti } \\
\text { upis u: } \\
\text { 345. Knjiga } \\
\text { mrtvacah } \\
\text { obiteljskih } \\
\text { grobnica } \\
\text { 1902.-1919., } \\
\text { red. br. } 228\end{array}$ \\
\hline 127 & 388 & $\begin{array}{c}\text { Max Živko } \\
\text { vojnik Zamlaka }\end{array}$ & $\begin{array}{l}24 \text { god. } \\
\text { neož. } \\
\text { Zamlaka }\end{array}$ & $\begin{array}{l}\text { Zamlaka } \\
\text { Varaždin }\end{array}$ & Dizenterija & $\begin{array}{l}25.10 . \\
1918 .\end{array}$ & $\begin{array}{c}13 \text { tabla } \\
7 \text { red } \\
\text { br. } 388\end{array}$ & $\begin{array}{l}\text { Počasni } \\
\text { grob. Isti } \\
\text { upis u: } \\
\text { 345. Knjiga } \\
\text { mrtvacah } \\
\text { obiteljskih } \\
\text { grobnica } \\
\text { 1902.-1919., } \\
\text { red. br. } 471\end{array}$ \\
\hline 128 & 376 & $\begin{array}{c}\text { Ignac Pintarić } \\
\text { sanitet }\end{array}$ & $\begin{array}{l}37 \text { god. } \\
\text { oženjen } \\
\text { Varaždin }\end{array}$ & & Gripa & $\begin{array}{l}20.10 . \\
1918 .\end{array}$ & $\begin{array}{c}13 \text { tabla } \\
1 \text { red } \\
\text { br. } 376\end{array}$ & $\begin{array}{l}\text { Počasni } \\
\text { grob. Isti } \\
\text { upis u: } \\
\text { 345. Knjiga } \\
\text { mrtvacah } \\
\text { obiteljskih } \\
\text { grobnica } \\
\text { 1902.-1919., } \\
\text { red. br. } 458\end{array}$ \\
\hline 129 & 373 & $\begin{array}{c}\text { Tomo Borovec } \\
\text { vojnik } 62 \\
\text { top. p. }\end{array}$ & $\begin{array}{l}26 \text { god. } \\
\text { neož } \\
\text { Žarovnica }\end{array}$ & $\begin{array}{l}\text { Zarovnica } \\
\text { Ivanec }\end{array}$ & Upala pluća & $\begin{array}{c}19.10 . \\
1918 .\end{array}$ & $\begin{array}{c}13 \text { tabla } \\
1 \text { red } \\
\text { br. } 373\end{array}$ & Počasni grob \\
\hline 130 & 357 & $\begin{array}{l}\text { Johan } \\
\text { Dobovčak } \\
\text { vojnik }\end{array}$ & $\begin{array}{l}28 \text { god. } \\
\text { oženjen } \\
\text { Varaždin }\end{array}$ & Varaždin & Upala pluća & $\begin{array}{l}14.10 . \\
1918 .\end{array}$ & $\begin{array}{c}13 \text { tabla } \\
1 \text { red } \\
\text { br. } 357\end{array}$ & $\begin{array}{l}\text { Počasni } \\
\text { grob. Isti } \\
\text { upis u: } \\
\text { 345. Knjiga } \\
\text { mrtvacah } \\
\text { obiteljskih } \\
\text { grobnica } \\
\text { 1902.-1919., } \\
\text { red. br. } 458\end{array}$ \\
\hline 131 & 348 & $\begin{array}{c}\text { Adam Pupovac } \\
\text { vojnik }\end{array}$ & $\begin{array}{c}36 \text { god. } \\
\text { oženjen } \\
\text { Belišani } \\
\text { Benkovac } \\
\text { Dalmatia }\end{array}$ & $\begin{array}{l}\text { Pričuvna } \\
\text { bolnica III. }\end{array}$ & Rubeola & $\begin{array}{l}9.10 . \\
1918 .\end{array}$ & $\begin{array}{c}13 \text { tabla } \\
7 \text { red } \\
\text { br. } 348\end{array}$ & $\begin{array}{l}\text { Počasni } \\
\text { grob }\end{array}$ \\
\hline 132 & 344 & $\begin{array}{l}\text { (?)milu Tessarin } \\
\text { talijan. zaroblj. }\end{array}$ & $\begin{array}{c}22 \text { god. } \\
\text { neoženjen } \\
\text { Kontarna(?) }\end{array}$ & $\begin{array}{l}\text { Kontarna(?) } \\
\text { Rovigo } \\
\text { Italija }\end{array}$ & Upala pluća & $\begin{array}{l}29.9 . \\
1918 .\end{array}$ & $\begin{array}{c}17 \text { tabla } \\
4 \text { red } \\
\text { br. } 344\end{array}$ & $\begin{array}{l}\text { Počasni } \\
\text { grob }\end{array}$ \\
\hline
\end{tabular}




\begin{tabular}{|c|c|c|c|c|c|c|c|c|}
\hline $\begin{array}{l}\text { Red. } \\
\text { broj }\end{array}$ & $\begin{array}{l}\text { Broj } \\
\text { groba }\end{array}$ & $\begin{array}{l}\text { Ime, prezime } \\
\text { i zanimanje }\end{array}$ & $\begin{array}{l}\text { doba, stališ } \\
\text { i rodno } \\
\text { mjesto }\end{array}$ & $\begin{array}{c}\text { mjesto } \\
\text { obitavanja }\end{array}$ & $\begin{array}{c}\text { posljednja } \\
\text { bolest } \\
\text { s koje je umro }\end{array}$ & $\begin{array}{c}\text { dan i } \\
\text { godina } \\
\text { kada je } \\
\text { sahranjen }\end{array}$ & Opazka & $\begin{array}{l}\text { Napomena } \\
\text { autora }\end{array}$ \\
\hline 133 & 342 & $\begin{array}{l}\text { Stjepan Švoger } \\
\text { ulaner k. u. k. } \\
5 \text { Reg. }\end{array}$ & $\begin{array}{l}36 \text { god. } \\
\text { neoženjen } \\
\text { Varaždin }\end{array}$ & Varaždin & Bolest pluća & $\begin{array}{l}26.9 . \\
1918 .\end{array}$ & $\begin{array}{c}13 \text { tabla } \\
1 \text { red } \\
\text { br. } 342\end{array}$ & Počasni grob \\
\hline 134 & 333 & $\begin{array}{c}\text { Štefan Mikac } \\
\text { vojnik } 36 \text { polj. } \\
\text { top. pukov. }\end{array}$ & $\begin{array}{l}32 \text { god. } \\
\text { udovac } \\
\text { Novaves }\end{array}$ & $\begin{array}{l}\text { Novaves } \\
\text { Petrijanec } \\
\text { Varaždin }\end{array}$ & Bolest trbuha & $\begin{array}{l}27.8 . \\
1918 .\end{array}$ & $\begin{array}{c}13 \text { tabla } \\
1 \text { red } \\
\text { br. } 333\end{array}$ & Počasni grob \\
\hline
\end{tabular}

345. Knjiga mrtvacah obiteljskih grobnica 1902.-1919.

\begin{tabular}{|c|c|c|c|c|c|c|c|}
\hline $\begin{array}{l}\text { Red. } \\
\text { broj }\end{array}$ & $\begin{array}{l}\text { Broj } \\
\text { groba }\end{array}$ & $\begin{array}{l}\text { Ime, prezime } \\
\text { i zanimanje }\end{array}$ & $\begin{array}{l}\text { doba, stališ } \\
\text { i rodno } \\
\text { mjesto }\end{array}$ & $\begin{array}{c}\text { mjesto } \\
\text { obitavanja }\end{array}$ & $\begin{array}{c}\text { posljednja } \\
\text { bolest } \\
\text { s koje je umro }\end{array}$ & $\begin{array}{c}\text { dan i godina kada } \\
\text { je sahranjen }\end{array}$ & Opazka \\
\hline 135 & 146 & $\begin{array}{l}\text { Dragutin } \\
\text { Pokupčić } \\
\text { c. i kr. vojni } \\
\text { nad(?) }\end{array}$ & $\begin{array}{l}55 \text { god. star } \\
\text { oženjen } \\
\text { (?) Slavonija }\end{array}$ & $\begin{array}{l}\text { Optujska } \\
\text { ulica } 26\end{array}$ & Upala & 10. 4. 1915. & $\begin{array}{c}1 \text { odjel } \\
1 \text { razred } \\
13 \text { red } \\
\text { br. groba } 2\end{array}$ \\
\hline 136 & 155 & $\begin{array}{l}\text { Marko Borović } \\
\text { nadračunovodja } \\
\text { kr. ug. 10. dom. } \\
\text { hus. pukovnije }\end{array}$ & $\begin{array}{c}34 \text { god. star } \\
\text { oženjen } \\
\text { Drenovci } \\
\text { kot. Županja } \\
\text { Slavonija }\end{array}$ & $\begin{array}{l}\text { Kapucinska } \\
\text { ulica } 7\end{array}$ & Bolest srca & 13. 12. 1915. & $\begin{array}{c}8 \text { odjel } \\
1 \text { razred } \\
15 \text { red } \\
\text { br. groba } 22\end{array}$ \\
\hline 137 & 300 & $\begin{array}{l}\text { Franjo Černy } \\
\text { c. k. (?) pješak }\end{array}$ & $\begin{array}{c}\text { oko 3o god. } \\
\text { oženjen } \\
\text { Pušča } \\
\text { Slatina }\end{array}$ & $\begin{array}{l}\text { Pričuvna } \\
\text { bolnica }\end{array}$ & $\begin{array}{l}\text { Prostrijelne } \\
\text { rane }\end{array}$ & 5. 10. 1914. & $\begin{array}{c}13 \text { odjel } \\
2 \text { razred } \\
4 \text { red } \\
\text { br. groba } 2\end{array}$ \\
\hline 138 & 316 & $\begin{array}{l}\text { Josip Trnovec } \\
\text { Res. Infanterist }\end{array}$ & $\begin{array}{l}31 \text { god. star } \\
\text { neoženjen } \\
\text { Varaždin } \\
\text { stolar }\end{array}$ & $\begin{array}{l}\text { Pričuvna } \\
\text { bolnica } \\
\text { III. odjel }\end{array}$ & Višestruke rane & 15. (?) 1914. & $\begin{array}{l}13 \text { odjel } \\
2 \text { razred } \\
4 \text { red } \\
\text { br. groba } 8\end{array}$ \\
\hline 139 & 326 & $\begin{array}{l}\text { Stjepan Nemet } \\
\text { Infanterist c. i } \\
\text { k. (?) husar. reg. } \\
28 \text { (?) }\end{array}$ & $\begin{array}{l}21 \text { god. star } \\
\text { oženjen } \\
\text { (?) Osijek } \\
\text { Croatien }\end{array}$ & $\begin{array}{l}\text { Pričuvna } \\
\text { bolnica } \\
\text { III. odjel }\end{array}$ & Tifus & 9. 1. 1915. & $\begin{array}{l}13 \text { odjel } \\
2 \text { razred } \\
5 \text { red } \\
\text { br. groba } 17\end{array}$ \\
\hline
\end{tabular}


Vladimir Huzjan: Vojne žrtve Velikog rata i poraća pokopane na varaždinskom groblju (1914.-1919.)

Radovi Zavoda za znanstveni rad HAZU Varaždin; br. 29, 2018., str. 179-222

\begin{tabular}{|c|c|c|c|c|c|c|c|}
\hline $\begin{array}{l}\text { Red. } \\
\text { broj }\end{array}$ & $\begin{array}{c}\text { Broj } \\
\text { groba }\end{array}$ & $\begin{array}{l}\text { Ime, prezime } \\
\text { i zanimanje }\end{array}$ & $\begin{array}{l}\text { doba, stališ } \\
\text { i rodno } \\
\text { mjesto }\end{array}$ & $\begin{array}{c}\text { mjesto } \\
\text { obitavanja }\end{array}$ & $\begin{array}{c}\text { posljednja } \\
\text { bolest } \\
\text { s koje je umro }\end{array}$ & $\begin{array}{c}\text { dan i godina kada } \\
\text { je sahranjen }\end{array}$ & Opazka \\
\hline 140 & 328 & $\begin{array}{c}\text { Franz Šešek } \\
\text { handsturmman } \\
\text { des haudt. rgt. } \\
27,3 \text { (?) }\end{array}$ & $\begin{array}{l}39 \text { god. star } \\
\text { oženjen } \\
\text { (?) Br. Stein } \\
\text { Krain }\end{array}$ & $\begin{array}{c}\text { Pričuvna } \\
\text { bolnica } \\
\text { V. }\end{array}$ & (?) & 10. 1. 1915. & $\begin{array}{c}13 \text { odjel } \\
2 \text { razred } \\
9 \text { red } \\
\text { br. groba } 21\end{array}$ \\
\hline 141 & 330 & $\begin{array}{l}\text { Stanko Pušić } \\
\text { (?) resez. c. u. k. } \\
\text { H. R. 27. } 2 \\
\text { comp. }\end{array}$ & $\begin{array}{l}29 \text { god. star } \\
\text { oženjen } \\
\text { Virje }\end{array}$ & (?) & Tifus & 26. 1. 1915. & $\begin{array}{c}13 \text { odjel } \\
2 \text { razred } \\
9 \text { red } \\
\text { br. groba } 25\end{array}$ \\
\hline 142 & 331 & $\begin{array}{l}\text { Tomo Čanjevac } \\
\text { kr. ug. dom. } \\
\text { podpukovnik }\end{array}$ & $\begin{array}{l}54 \text { g. star } \\
\text { oženjen } \\
\text { Varaždin }\end{array}$ & $\begin{array}{c}\text { Beč, } \\
\text { odavle } \\
\text { prevezen }\end{array}$ & (?) & 2. 2. 1915 . & $\begin{array}{c}13 \text { odjel } \\
2 \text { razred } \\
1 \text { red } \\
\text { br. groba } 2\end{array}$ \\
\hline 143 & 332 & $\begin{array}{c}\text { Josip Opal } \\
\text { husar } 10 . \text { hus. } \\
\text { pukovnije }\end{array}$ & $\begin{array}{c}23 \text { god. star } \\
\text { neoženjen } \\
\text { Gorica kod } \\
\text { (?) }\end{array}$ & $\begin{array}{l}\text { Pričuvna } \\
\text { bolnica II. }\end{array}$ & Tuberkuloza & 3. 2. 1915. & $\begin{array}{c}13 \text { odjel } \\
2 \text { razred } \\
9 \text { red } \\
\text { br. groba } 24\end{array}$ \\
\hline 144 & 383 & $\begin{array}{l}\text { Ivan Gaščić } \\
\text { (?) div } 13 \\
\text { Landman }\end{array}$ & 24 god. star & $\begin{array}{l}\text { Pričuvna } \\
\text { bolnica } \\
\text { Varaždin }\end{array}$ & Tuberkuloza & 28. 6. 1915. & $\begin{array}{c}13 \text { odjel } \\
7 \text { red } \\
2 \text { razred } \\
\text { br. groba } 42\end{array}$ \\
\hline 145 & 384 & $\begin{array}{l}\text { Vinko Zaluški } \\
\text { kr. ug. domb. } \\
\text { stražmeštar }\end{array}$ & $\begin{array}{l}46 \text { god. star } \\
\text { oženjen } \\
\text { Vinkovci }\end{array}$ & $\begin{array}{l}\text { Kapucinska } \\
\text { ulica } 14\end{array}$ & Tuberkuloza & 13. 7. 1915. & $\begin{array}{c}13 \text { odjel } \\
7 \text { red } \\
2 \text { razred } \\
\text { br. groba } 46\end{array}$ \\
\hline 146 & 385 & $\begin{array}{l}\text { Marko Rula } \\
\text { Inf. K. u. k. inf. } \\
\text { regm. } 96,14 \\
\text { korp. }\end{array}$ & $\begin{array}{c}22 \text { Jahre alt } \\
\text { ledig } \\
\text { Belevode } \\
\text { Ogulin } \\
\text { Hrvatska }\end{array}$ & $\begin{array}{l}\text { Rezervna } \\
\text { bolnica }\end{array}$ & Meningitis & 16. 7. 1915. & $\begin{array}{c}13 \text { odjel } \\
7 \text { red } \\
\text { br. groba } 44\end{array}$ \\
\hline
\end{tabular}


Vladimir Huzjan: Vojne žrtve Velikog rata i poraća pokopane na varaždinskom groblju (1914.-1919.)

Radovi Zavoda za znanstveni rad HAZU Varaždin; br. 29, 2018., str. 179-222

\begin{tabular}{|c|c|c|c|c|c|c|c|}
\hline $\begin{array}{l}\text { Red. } \\
\text { broj }\end{array}$ & $\begin{array}{l}\text { Broj } \\
\text { groba }\end{array}$ & $\begin{array}{l}\text { Ime, prezime } \\
\text { i zanimanje }\end{array}$ & $\begin{array}{l}\text { doba, stališ } \\
\text { i rodno } \\
\text { mjesto }\end{array}$ & $\begin{array}{c}\text { mjesto } \\
\text { obitavanja }\end{array}$ & $\begin{array}{c}\text { posljednja } \\
\text { bolest } \\
\text { s koje je umro }\end{array}$ & $\begin{array}{c}\text { dan i godina kada } \\
\text { je sahranjen }\end{array}$ & Opazka \\
\hline 147 & 387 & $\begin{array}{l}\text { Mijo Matesić } \\
\text { inf. des. K. u. K. } \\
\text { inf. regmt. 96, } 7 . \\
\text { Feldkorp. }\end{array}$ & $\begin{array}{c}25 \text { Jahre alt } \\
\text { ledig } \\
\text { Grljak } \\
\text { Petrovina } \\
\text { Jaska } \\
\text { Hrvatska }\end{array}$ & (?) & $\begin{array}{l}\text { Prostrijelne } \\
\text { rane }\end{array}$ & 27. 7. 1915. & $\begin{array}{c}13 \text { odjel } \\
7 \text { red } \\
\text { br. groba } 50\end{array}$ \\
\hline 148 & 390 & $\begin{array}{c}\text { Josef Vrkić } \\
\text { Inf. K. u. K. } \\
\text { Lander Inf. Reg. } \\
23\end{array}$ & $\begin{array}{l}27 \text { god. star } \\
\text { neoženjen } \\
\text { Kruševo } \\
\text { (?) Benkovac } \\
\text { Dalmatia }\end{array}$ & (?) & $\begin{array}{l}\text { Prostrijelne } \\
\text { rane }\end{array}$ & 2. 8. 1915 . & $\begin{array}{c}13 \text { odjel } \\
2 \text { razred } \\
7 \text { red } \\
\text { br. groba } 49\end{array}$ \\
\hline 149 & 392 & $\begin{array}{l}\text { Dušan Jajanin } \\
\text { Res. corp. des } \\
\text { K. u. K. inf. reg. } \\
\text { nr. } 96\end{array}$ & $\begin{array}{l}29 \text { jahre alt } \\
\text { oženjen } \\
\text { Bečuga } \\
\text { Glina } \\
\text { Hrvatska }\end{array}$ & (?) & $\begin{array}{l}\text { Prostrijelne } \\
\text { rane }\end{array}$ & 5. 8. 1915. & $\begin{array}{c}13 \text { odjel } \\
2 \text { razred } \\
8 \text { red } \\
\text { br. groba } 53\end{array}$ \\
\hline 150 & 393 & $\begin{array}{l}\text { Gjuro Vuletić } \\
\text { inf. des K. u. K. } \\
\text { inf. reg. } 96 \text { m. } \\
\text { g. o. }\end{array}$ & $\begin{array}{l}26 \text { g. star } \\
\text { oženjen } \\
\text { Miholjska } \\
\text { (?) Hrvatska }\end{array}$ & (?) & $\begin{array}{l}\text { Prostrijelne } \\
\text { rane }\end{array}$ & 5. 8. 1915. & $\begin{array}{c}13 \text { odjel } \\
2 \text { razred } \\
8 \text { red } \\
\text { br. groba } 55\end{array}$ \\
\hline 151 & 402 & $\begin{array}{l}\text { Ivan Domiter } \\
\text { Inf. d. k. u. k. } \\
\text { reg. (?) } 25\end{array}$ & $\begin{array}{l}40 \text { god. star } \\
\text { oženjen } \\
\text { Kneginec } \\
\text { Varaždin }\end{array}$ & $(?)$ & $\begin{array}{l}\text { Prostrijelne } \\
\text { rane }\end{array}$ & 19. 8. 1915. & $\begin{array}{c}13 \text { odjel } \\
2 \text { razred } \\
1 \text { red } \\
\text { br. groba } 9\end{array}$ \\
\hline 152 & 413 & $\begin{array}{c}\text { Štefan Hlupić } \\
\text { Inf. d. K. u. K. } \\
\text { inf. } \\
\text { reg. } 53,4 \text {. corp. }\end{array}$ & $\begin{array}{l}25 \text { god. star } \\
\text { oženjen } \\
\text { Jelčovac } \\
\text { Pregrada } \\
\text { Kroatien } \\
\end{array}$ & (?) & Tuberkuloza & 4. 10. 1915. & $\begin{array}{c}13 \text { odjel } \\
6 \text { red } \\
\text { br. groba } 27\end{array}$ \\
\hline 153 & 415 & $\begin{array}{c}\text { Petar Pomek } \\
\text { handsturman d. } \\
\text { K. u. k. Inf. r. } 25\end{array}$ & $\begin{array}{l}38 \text { god. star } \\
\text { oženjen } \\
\text { Leštakovec } \\
\text { Varaždin }\end{array}$ & $\begin{array}{l}\text { Pričuvna } \\
\text { bolnica }\end{array}$ & (?) & 23. 10. 1915. & $\begin{array}{c}13 \text { odjel } \\
6 \text { red } \\
\text { br. groba } 98\end{array}$ \\
\hline 154 & 419 & $\begin{array}{l}\text { Petar Movričić } \\
\text { Inf. D. k. u. k. } \\
\text { inf. reg. } 96\end{array}$ & $\begin{array}{l}32 \text { Jahre alt } \\
\text { oženjen } \\
\text { Duga Resa } \\
\text { Karlovac }\end{array}$ & $\begin{array}{l}\text { Pričuvna } \\
\text { bolnica }\end{array}$ & $\begin{array}{l}\text { Prostrijelne } \\
\text { rane }\end{array}$ & 6. 11. 1915. & $\begin{array}{l}13 \text { odjel } \\
6 \text { red } \\
\text { br. groba } \\
100\end{array}$ \\
\hline
\end{tabular}


Vladimir Huzjan: Vojne žrtve Velikog rata i poraća pokopane na varaždinskom groblju (1914.-1919.)

Radovi Zavoda za znanstveni rad HAZU Varaždin; br. 29, 2018., str. 179-222

\begin{tabular}{|c|c|c|c|c|c|c|c|}
\hline $\begin{array}{l}\text { Red. } \\
\text { broj }\end{array}$ & $\begin{array}{c}\text { Broj } \\
\text { groba }\end{array}$ & $\begin{array}{l}\text { Ime, prezime } \\
\text { i zanimanje }\end{array}$ & $\begin{array}{l}\text { doba, stališ } \\
\text { i rodno } \\
\text { mjesto }\end{array}$ & $\begin{array}{c}\text { mjesto } \\
\text { obitavanja }\end{array}$ & $\begin{array}{c}\text { posljednja } \\
\text { bolest } \\
\text { s koje je umro }\end{array}$ & $\begin{array}{c}\text { dan i godina kada } \\
\text { je sahranjen }\end{array}$ & Opazka \\
\hline 155 & 431 & $\begin{array}{l}\text { Mato Galić } \\
\text { Inf. d. bos. herz. } \\
\text { inf. reg. } 1 .\end{array}$ & $\begin{array}{l}37 \text { god. star } \\
\text { oženjen } \\
\text { Visoko } \\
\text { Bosnien }\end{array}$ & $\begin{array}{l}\text { Pričuvna } \\
\text { bolnica }\end{array}$ & Tetanus & 23.11. 1915. & $\begin{array}{c}13 \text { odjel } \\
2 \text { razred } \\
7 \text { red } \\
\text { br. groba } 54\end{array}$ \\
\hline 156 & 434 & $\begin{array}{c}\text { Josef Starešinić } \\
\text { handst. korporal } \\
\text { d. K. u. K. L. J. } \\
\text { R. } 3\end{array}$ & $\begin{array}{l}39 \text { god. star } \\
\text { oženjen } \\
\text { Velika } \\
\text { Gorica } \\
\text { Hrvatska }\end{array}$ & $\begin{array}{l}\text { Pričuvna } \\
\text { bolnica }\end{array}$ & $\begin{array}{l}\text { Prostrijelne } \\
\text { rane }\end{array}$ & 8. 1. 1916. & $\begin{array}{l}13 \text { odjel } \\
2 \text { razred } \\
7 \text { red } \\
\text { br. groba } \\
108\end{array}$ \\
\hline 157 & 435 & $\begin{array}{l}\text { Vaso Ignjac } \\
\text { (?) d. K. u. K. Ul. } \\
\text { Rg. } 5 .\end{array}$ & $\begin{array}{l}34 \text { god. star } \\
\text { oženjen } \\
\text { Hakovci } \\
\text { Livno Bosna }\end{array}$ & $\begin{array}{l}\text { Pričuvna } \\
\text { bolnica }\end{array}$ & Upala pluća & 8. 1. 1916. & $\begin{array}{c}13 \text { odjel } \\
2 \text { razred } \\
7 \text { red } \\
\text { br. groba } 63\end{array}$ \\
\hline 158 & 148 & $\begin{array}{l}\text { Mato Eterović } \\
\text { Inf. D. K. u. K. (?) } \\
\text { 23., 6. korp }\end{array}$ & $\begin{array}{c}27 \text { god. star } \\
\text { neoženjen } \\
\text { Pučišće } \\
\text { Brazzo } \\
\text { Dalmatia }\end{array}$ & $\begin{array}{l}\text { Pričuvna } \\
\text { bolnica }\end{array}$ & Velike boginje & 7. 5. 1916. & $\begin{array}{c}13 \text { odjel } \\
2 \text { razred } \\
\text { br. groba } 72\end{array}$ \\
\hline 159 & 151 & $\begin{array}{l}\text { Ivan Hrbarić } \\
\text { Inf. I. R. (?) }\end{array}$ & $\begin{array}{c}35 \text { god. star } \\
\text { oženjen } \\
\text { Velika } \\
\text { Pisanica } \\
\text { Slavonien }\end{array}$ & $\begin{array}{l}\text { Pričuvna } \\
\text { bolnica }\end{array}$ & Crijevna upala & 24. 6. 1916. & $\begin{array}{l}13 \text { odjel } \\
2 \text { razred } \\
\text { br. groba } \\
113\end{array}$ \\
\hline 160 & 172 & $\begin{array}{l}\text { Sime Mikulić } \\
\text { des Damjanus } \\
\text { Inf. K. K. (?) } 23\end{array}$ & $\begin{array}{l}20 \text { god. star } \\
\text { neoženjen } \\
\text { Čehoglas(?) }\end{array}$ & $\begin{array}{l}\text { Pričuvna } \\
\text { bolnica }\end{array}$ & Crijevna upala & 30. 9. 1916. & $\begin{array}{l}13 \text { odjel } \\
8 \text { red } \\
2 \text { razred } \\
\text { br. groba } \\
153\end{array}$ \\
\hline 161 & 188 & $\begin{array}{c}\text { Dane Gjekić } \\
\text { (?) Inf. K. u. K. J. } \\
\text { R. } 79\end{array}$ & $\begin{array}{l}34 \text { god. star } \\
\text { neoženjen } \\
\text { Gračac } \\
\text { Hrvatska }\end{array}$ & $\begin{array}{c}\text { Biškupećka } \\
58 a\end{array}$ & Tuberkuloza & 18. 1. 1917. & $\begin{array}{l}13 \text { odjel } \\
2 \text { razred } \\
\text { br. groba } \\
109\end{array}$ \\
\hline 162 & 194 & $\begin{array}{l}\text { Mika (?) Dumić } \\
\text { Inf. d. K. u. K. } \\
\text { hus 23, 3. korp }\end{array}$ & $\begin{array}{c}48 \text { god. star } \\
\text { oženjen } \\
\text { Lukoran } \\
\text { Zadar } \\
\text { Dalmatia }\end{array}$ & $\begin{array}{l}\text { Pričuvna } \\
\text { bolnica III. }\end{array}$ & Tuberkuloza & 4. 2. 1917 . & $\begin{array}{l}13 \text { odjel } \\
2 \text { razred } \\
\text { br. groba } \\
174\end{array}$ \\
\hline
\end{tabular}


Vladimir Huzjan: Vojne žrtve Velikog rata i poraća pokopane na varaždinskom groblju (1914.-1919.)

Radovi Zavoda za znanstveni rad HAZU Varaždin; br. 29, 2018., str. 179-222

\begin{tabular}{|c|c|c|c|c|c|c|c|}
\hline $\begin{array}{l}\text { Red. } \\
\text { broj }\end{array}$ & $\begin{array}{c}\text { Broj } \\
\text { groba }\end{array}$ & $\begin{array}{l}\text { Ime, prezime } \\
\text { i zanimanje }\end{array}$ & $\begin{array}{l}\text { doba, stališ } \\
\text { i rodno } \\
\text { mjesto }\end{array}$ & $\begin{array}{c}\text { mjesto } \\
\text { obitavanja }\end{array}$ & $\begin{array}{c}\text { posljednja } \\
\text { bolest } \\
\text { s koje je umro }\end{array}$ & $\begin{array}{c}\text { dan i godina kada } \\
\text { je sahranjen }\end{array}$ & Opazka \\
\hline 163 & 196 & $\begin{array}{l}\text { Franz d. Stipe } \\
\text { Jurić } \\
\text { Inf. D. K. u. K. } \\
\text { hus 23., } 4 \text { korp }\end{array}$ & $\begin{array}{l}27 \text { god. star } \\
\text { oženjen } \\
\text { Vedropolje } \\
\text { Bihać } \\
\text { Bosnien }\end{array}$ & $\begin{array}{l}\text { Pričuvna } \\
\text { bolnica III. }\end{array}$ & (?) & 10. 2. 1917. & $\begin{array}{c}13 \text { odjel } \\
2 \text { razred } \\
\text { br. groba } \\
177\end{array}$ \\
\hline 164 & 198 & $\begin{array}{l}\text { Imbro Canjuga } \\
\text { Inf. D. K. u. K. } \\
25 \text { hus }\end{array}$ & $\begin{array}{l}51 \text { god. star } \\
\text { oženjen } \\
\text { Jerovec } \\
\text { Ivanec } \\
\text { Varaždin }\end{array}$ & $\begin{array}{l}\text { Pričuvna } \\
\text { bolnica }\end{array}$ & Upala pluća & 16. 2. 1917. & $\begin{array}{c}13 \text { odjel } \\
2 \text { razred } \\
\text { br. groba } \\
179\end{array}$ \\
\hline 165 & 201 & $\begin{array}{l}\text { Mato Andrašić } \\
\text { (?) des s. (?) R. } 7 .\end{array}$ & $\begin{array}{l}29 \text { god. star } \\
\text { oženjen } \\
\text { Gradec } \\
\text { Križevci }\end{array}$ & $\begin{array}{l}\text { Pričuvna } \\
\text { bolnica III. }\end{array}$ & Upala pluća & 26. 2. 1917. & $\begin{array}{c}13 \text { odjel } \\
1 \text { razred } \\
\text { br. groba } \\
180\end{array}$ \\
\hline 166 & 203 & $\begin{array}{l}\text { Lovro Vertuš } \\
\text { Inf. D. K. u. K. J. } \\
\text { R. } 25\end{array}$ & $\begin{array}{l}51 \text { god. star } \\
\text { oženjen } \\
\text { Visoko } \\
\text { Novimrof }\end{array}$ & $\begin{array}{l}\text { Pričuvna } \\
\text { bolnica III. }\end{array}$ & Meningitis & 7. 3. 1917. & $\begin{array}{c}13 \text { odjel } \\
1 \text { red } \\
2 \text { razred } \\
\text { br. groba } \\
182\end{array}$ \\
\hline 167 & 204 & $\begin{array}{l}\text { Josip Hević } \\
\text { Inf. D. K. u. K. } \\
\text { hus 23, } 1 \text { korp. }\end{array}$ & $\begin{array}{l}44 \text { god. star } \\
\text { oženjen } \\
\text { Nevest Knin } \\
\text { Dalmatia }\end{array}$ & $\begin{array}{l}\text { Pričuvna } \\
\text { bolnica III. }\end{array}$ & Bolest bubrega & 7. 3. 1917. & $\begin{array}{l}13 \text { odjel } \\
1 \text { red } \\
\text { br. groba } \\
183\end{array}$ \\
\hline 168 & 206 & $\begin{array}{l}\text { Ivo Pleinić } \\
\text { (?) }\end{array}$ & $\begin{array}{l}22 \text { god. star } \\
\text { neoženjen } \\
\text { Priseka Ključ } \\
\text { Bosna }\end{array}$ & (?) & Tuberkuloza & 26. 3. 1917. & $\begin{array}{l}13 \text { odjel } \\
1 \text { red } \\
\text { br. groba } \\
185\end{array}$ \\
\hline 169 & 210 & $\begin{array}{l}\text { Juraj Peršić } \\
\text { R (?) } 10\end{array}$ & $\begin{array}{c}30 \text { god. star } \\
\text { oženjen } \\
\text { Hosinac } \\
\text { Gračac } \\
\text { Kroatien }\end{array}$ & $\begin{array}{l}\text { Pričuvna } \\
\text { bolnica III. }\end{array}$ & Tifus & 22. 4. 1917. & $\begin{array}{c}13 \text { odjel } \\
2 \text { razred } \\
\text { br. groba } \\
189\end{array}$ \\
\hline 170 & 216 & $\begin{array}{l}\text { Ljuboje Kordić } \\
\text { Jaeger d. bh } \\
\text { Feldjaeger } \\
\text { (?) No. 6, } 1 \text { korp }\end{array}$ & $\begin{array}{l}30 \text { god. star } \\
\text { oženjen } \\
\text { (?)ključani } \\
\text { Dubica } \\
\text { Bosnien } \\
\end{array}$ & $\begin{array}{l}\text { Gradska } \\
\text { bolnica }\end{array}$ & (?) & 2. 5. 1917 . & $\begin{array}{c}13 \text { odjel } \\
2 \text { razred } \\
\text { br. groba } \\
194\end{array}$ \\
\hline 171 & 219 & $\begin{array}{l}\text { Antun Marković } \\
\text { Inf. (?) J. R. 5, } \\
5 \text { k. }\end{array}$ & $\begin{array}{l}42 \text { god. star } \\
\text { oženjen } \\
\text { Pisino (?) } \\
\text { Istrien }\end{array}$ & $\begin{array}{l}\text { Pričuvna } \\
\text { bolnica III. }\end{array}$ & Tuberkuloza & 5. 5. 1917. & $\begin{array}{c}13 \text { odjel } \\
2 \text { razred } \\
\text { br. groba } \\
196\end{array}$ \\
\hline
\end{tabular}


Vladimir Huzjan: Vojne žrtve Velikog rata i poraća pokopane na varaždinskom groblju (1914.-1919.)

Radovi Zavoda za znanstveni rad HAZU Varaždin; br. 29, 2018., str. 179-222

\begin{tabular}{|c|c|c|c|c|c|c|c|}
\hline $\begin{array}{l}\text { Red. } \\
\text { broj }\end{array}$ & $\begin{array}{c}\text { Broj } \\
\text { groba }\end{array}$ & $\begin{array}{l}\text { Ime, prezime } \\
\text { i zanimanje }\end{array}$ & $\begin{array}{l}\text { doba, stališ } \\
\text { i rodno } \\
\text { mjesto }\end{array}$ & $\begin{array}{c}\text { mjesto } \\
\text { obitavanja }\end{array}$ & $\begin{array}{c}\text { posljednja } \\
\text { bolest } \\
\text { s koje je umro }\end{array}$ & $\begin{array}{c}\text { dan i godina kada } \\
\text { je sahranjen }\end{array}$ & Opazka \\
\hline 172 & 262 & $\begin{array}{c}\text { Lacko Ban } \\
\text { Inf, K. K. J. R. } 53\end{array}$ & $\begin{array}{l}22 \text { god. star } \\
\text { oženjen } \\
\text { Djelekovac } \\
\quad \text { Zlatar }\end{array}$ & $\begin{array}{l}\text { Pričuvna } \\
\text { bolnica III. }\end{array}$ & Tuberkuloza & 4. 7. 1917. & $\begin{array}{c}13 \text { odjel } \\
2 \text { razred } \\
\text { br. groba } \\
217\end{array}$ \\
\hline 173 & 265 & $\begin{array}{c}\text { Gjuro Ban } \\
\text { Ulan ul. puk. } 12\end{array}$ & $?$ & $?$ & Ubio se & 17. 8. 1917. & $\begin{array}{c}13 \text { odjel } \\
2 \text { razred } \\
\text { br. groba } \\
219\end{array}$ \\
\hline 174 & 289 & $\begin{array}{c}\text { Jovan Paunović } \\
\text { Kr. Serb. (?) }\end{array}$ & $\begin{array}{l}20 \text { god. star } \\
\text { Kragujevac } \\
\text { Serbien }\end{array}$ & $\begin{array}{l}\text { Pričuvna } \\
\text { bolnica III. }\end{array}$ & Tuberkuloza & 19. 9. 1917. & $\begin{array}{c}13 \text { odjel } \\
2 \text { razred } \\
\text { br. groba } \\
242\end{array}$ \\
\hline 175 & 324 & $\begin{array}{l}\text { Fodor Bašić } \\
\text { Inf. (?) K. K. } \\
\text { (?) } 15\end{array}$ & $\begin{array}{l}38 \text { god. star } \\
\text { oženjen } \\
\text { Bržinci } \\
\text { (?) Bosnien }\end{array}$ & $\begin{array}{l}\text { Pričuvna } \\
\text { bolnica III. }\end{array}$ & Meningitis & 7. 1. 1918. & $\begin{array}{c}13 \text { odjel } \\
2 \text { razred } \\
\text { br. groba } \\
273\end{array}$ \\
\hline 176 & 328 & $\begin{array}{c}\text { Šerif Čoralić } \\
\text { Jaeger d. K. u. K. } \\
\text { BH J. B. } 6\end{array}$ & $\begin{array}{c}35 \text { god. star } \\
\text { oženjen } \\
\text { Kozarac } \\
\text { Prijedor Luka } \\
\text { Bosna }\end{array}$ & $\begin{array}{l}\text { Pričuvna } \\
\text { bolnica III. }\end{array}$ & Upala pluća & 8. 1. 1918. & $\begin{array}{l}13 \text { odjel } \\
2 \text { razred } \\
\text { br. groba } \\
276\end{array}$ \\
\hline 177 & 329 & $\begin{array}{l}\text { Gjuro Lenardić } \\
\text { husar (?) } 10\end{array}$ & $\begin{array}{l}41 \text { god. star } \\
\text { oženjen } \\
\text { Mičelinac } \\
\text { Gjurgjevac }\end{array}$ & $\begin{array}{l}\text { Pričuvna } \\
\text { bolnica III. }\end{array}$ & Tuberkuloza & 15. 1. 1918. & $\begin{array}{c}13 \text { odjel } \\
2 \text { razred } \\
\text { br. groba } \\
277\end{array}$ \\
\hline 178 & 335 & $\begin{array}{l}\text { Josip Riberski } \\
\text { Inf. K. u. K. H. J. } \\
\text { R. } 25\end{array}$ & $\begin{array}{l}21 \text { god. star } \\
\text { oženjen } \\
\text { (?) Zlatar }\end{array}$ & $\begin{array}{l}\text { Pričuvna } \\
\text { bolnica III. }\end{array}$ & $\begin{array}{l}\text { Prostrijelne } \\
\text { rane }\end{array}$ & 21. 1. 1918. & $\begin{array}{c}13 \text { odjel } \\
2 \text { razred } \\
\text { br. groba } \\
281\end{array}$ \\
\hline 179 & 338 & $\begin{array}{c}\text { Pavao Ivošević } \\
\text { (?) K. U. K. (?) } \\
\text { Zgb }\end{array}$ & $\begin{array}{l}31 \text { god. star } \\
\text { oženjen } \\
\text { (?) Vojnić } \\
\text { Ogulin }\end{array}$ & $\begin{array}{l}\text { Pričuvna } \\
\text { bolnica III. }\end{array}$ & $\begin{array}{l}\text { Prostrijelne } \\
\text { rane }\end{array}$ & 1. 2. 1918. & $\begin{array}{l}13 \text { odjel } \\
2 \text { razred } \\
\text { br. groba } \\
284\end{array}$ \\
\hline 180 & 347 & $\begin{array}{c}\text { Franz Mikulčić } \\
\text { Infanterist }\end{array}$ & $\begin{array}{l}23 \text { god. star } \\
\text { neoženjen } \\
\text { (?) Zlatar }\end{array}$ & $\begin{array}{l}\text { Pričuvna } \\
\text { bolnica }\end{array}$ & Tuberkuloza & 2. 3. 1918 . & $\begin{array}{c}13 \text { odjel } \\
2 \text { razred } \\
\text { br. groba } \\
289\end{array}$ \\
\hline
\end{tabular}


Vladimir Huzjan: Vojne žrtve Velikog rata i poraća pokopane na varaždinskom groblju (1914.-1919.)

Radovi Zavoda za znanstveni rad HAZU Varaždin; br. 29, 2018., str. 179-222

\begin{tabular}{|c|c|c|c|c|c|c|c|}
\hline $\begin{array}{l}\text { Red. } \\
\text { broj }\end{array}$ & $\begin{array}{l}\text { Broj } \\
\text { groba }\end{array}$ & $\begin{array}{l}\text { Ime, prezime } \\
\text { i zanimanje }\end{array}$ & $\begin{array}{l}\text { doba, stališ } \\
\text { i rodno } \\
\text { mjesto }\end{array}$ & $\begin{array}{c}\text { mjesto } \\
\text { obitavanja }\end{array}$ & $\begin{array}{c}\text { posljednja } \\
\text { bolest } \\
\text { s koje je umro }\end{array}$ & $\begin{array}{c}\text { dan i godina kada } \\
\text { je sahranjen }\end{array}$ & Opazka \\
\hline 181 & 350 & $\begin{array}{l}\text { Nikola Kostelac } \\
\text { gosp. Šum. } \\
\text { činovnik } \\
\text { pješak c. i k. } 79 \\
\text { pješ. puk. }\end{array}$ & $\begin{array}{l}23 \text { god. star } \\
\text { neoženjen } \\
\text { Gračac }\end{array}$ & $\begin{array}{l}\text { Trenkova } \\
\text { ul. } 2\end{array}$ & Bolesti trbuha & 3. 9. 1918. & $\begin{array}{c}13 \text { odjel } \\
2 \text { razred } \\
\text { br. groba } \\
316\end{array}$ \\
\hline 182 & 175 & $\begin{array}{c}\text { Radoje Peršić } \\
\text { pješak/ srbski } \\
\text { ratni zarobljenik }\end{array}$ & 22 god. star & (?) & (?) & (?) & $\begin{array}{c}18 \text { odjel } \\
2 \text { razred } \\
7 \text { red } \\
\text { br. groba } \\
801\end{array}$ \\
\hline 183 & 176 & $\begin{array}{c}\text { Jovan Velković } \\
\text { Kr. srbski pješak } \\
\text { Timočke divizije } \\
14 \text { puk. }\end{array}$ & $\begin{array}{l}22 \text { god. star } \\
\text { oženjen } \\
\text { (?) Srbija }\end{array}$ & $\begin{array}{l}\text { Pričuvna } \\
\text { bolnica II. }\end{array}$ & Tetanus & 25. 11. 1914. & $\begin{array}{c}18 \text { odjel } \\
2 \text { razred } \\
7 \text { red } \\
\text { br. groba } \\
802\end{array}$ \\
\hline 184 & 177 & $\begin{array}{c}\text { Svetozar Vučić } \\
\text { kr. srbski pješak } \\
\text { Timočka divizija } \\
13 \text { puk. }\end{array}$ & $\begin{array}{l}22 \text { god. star } \\
\text { oženjen } \\
\text { Planina srez } \\
\text { Valjevački } \\
\text { Srbija }\end{array}$ & $\begin{array}{l}\text { Pričuvna } \\
\text { bolnica II. }\end{array}$ & Tifus & 6. 1. 1915. & $\begin{array}{c}18 \text { odjel } \\
2 \text { razred } \\
7 \text { red } \\
\text { br. groba } \\
803\end{array}$ \\
\hline 185 & 178 & $\begin{array}{c}\text { Milovan } \\
\text { Angjelković } \\
\text { Inf. Srbski } \\
\text { zarobljenik } \\
\text { Srb 8. puk (?) }\end{array}$ & $\begin{array}{l}26 \text { god. star } \\
\text { oženjen } \\
\text { (?) Srbija }\end{array}$ & $\begin{array}{l}\text { Pričuvna } \\
\text { bolnica VII. }\end{array}$ & Tifus & 29. 1. 1915. & $\begin{array}{c}18 \text { odjel } \\
2 \text { razred } \\
7 \text { red } \\
\text { br. groba } \\
804\end{array}$ \\
\hline 186 & 204 & $\begin{array}{l}\text { Dušan Denić } \\
\text { (?) Serb. J. R. } 10 \\
\text { / VI B }\end{array}$ & $\begin{array}{l}\text { Banovo } \\
\text { Srbija }\end{array}$ & $\begin{array}{l}\text { Pričuvna } \\
\text { bolnica VII. }\end{array}$ & $\begin{array}{l}\text { Prostrijelne } \\
\text { rane }\end{array}$ & 24. 6. 1917. & $\begin{array}{c}13 \text { odjel } \\
2 \text { razred } \\
\text { br. groba } \\
217\end{array}$ \\
\hline 187 & 362 & $\begin{array}{c}\text { Franz Gradičić } \\
\text { Husar (?) }\end{array}$ & $\begin{array}{c}43 \text { god. star } \\
\text { oženjen } \\
\text { Otočac }\end{array}$ & $\begin{array}{c}\text { Zagrebačka } \\
5\end{array}$ & (?) & 5. 5. 1918. & $\begin{array}{c}13 \text { odjel } \\
2 \text { razred } \\
7 \text { red } \\
\text { br. groba } \\
312\end{array}$ \\
\hline 188 & 374 & $\begin{array}{l}\text { Mirko Martan } \\
\text { K. K. (?) } 17\end{array}$ & $\begin{array}{l}23 \text { god. star } \\
\text { (?) Podrute }\end{array}$ & $\begin{array}{l}\text { Gradska } \\
\text { bolnica }\end{array}$ & $\begin{array}{l}\text { Ubio se iz } \\
\text { puške }\end{array}$ & 25. 6. 1918. & $\begin{array}{c}13 \text { odjel } \\
2 \text { razred } \\
7 \text { red } \\
\text { br. groba } \\
310\end{array}$ \\
\hline
\end{tabular}


Vladimir Huzjan: Vojne žrtve Velikog rata i poraća pokopane na varaždinskom groblju (1914.-1919.)

Radovi Zavoda za znanstveni rad HAZU Varaždin; br. 29, 2018., str. 179-222

\begin{tabular}{|c|c|c|c|c|c|c|c|}
\hline $\begin{array}{l}\text { Red. } \\
\text { broj }\end{array}$ & $\begin{array}{l}\text { Broj } \\
\text { groba }\end{array}$ & $\begin{array}{l}\text { Ime, prezime } \\
\text { i zanimanje }\end{array}$ & $\begin{array}{l}\text { doba, stališ } \\
\text { i rodno } \\
\text { mjesto }\end{array}$ & $\begin{array}{c}\text { mjesto } \\
\text { obitavanja }\end{array}$ & $\begin{array}{c}\text { posljednja } \\
\text { bolest } \\
\text { s koje je umro }\end{array}$ & $\begin{array}{c}\text { dan i godina kada } \\
\text { je sahranjen }\end{array}$ & Opazka \\
\hline 189 & 450 & $\begin{array}{l}\text { Amfri Ratnony(?) } \\
\text { (?) Inf. Rm. (?) }\end{array}$ & $?$ & $\begin{array}{l}\text { Pričuvna } \\
\text { bolnica IV. }\end{array}$ & Gripa & 18. 10. 1918. & $\begin{array}{l}13 \text { odjel } \\
2 \text { razred } \\
\text { br. groba } \\
369\end{array}$ \\
\hline 190 & 452 & $\begin{array}{l}\text { Adam Stjepan } \\
\text { Sili } \\
\text { husar } 10 . \text { hus. } \\
\text { Pukovnije }\end{array}$ & $\begin{array}{l}35 \text { god. star } \\
\text { oženjen } \\
\text { Nedeljanec }\end{array}$ & Graberje 7 & Upala pluća & 18. 10. 1918. & $\begin{array}{l}13 \text { odjel } \\
2 \text { razred } \\
\text { br. groba } \\
370\end{array}$ \\
\hline 191 & 517 & $\begin{array}{c}\text { Franjo Moltes } \\
\text { pješak narodne } \\
\text { vojske SHS }\end{array}$ & $\begin{array}{l}31 \text { god. star } \\
\text { neoženjen } \\
\text { Podturen } \\
\text { Medjimurje }\end{array}$ & $\begin{array}{l}\text { Gradska } \\
\text { bolnica }\end{array}$ & $\begin{array}{l}\text { Prostrijelne } \\
\text { rane }\end{array}$ & 27. 2. 1919. & $\begin{array}{c}13 \text { odjel } \\
3 \text { polje } \\
8 \text { red } \\
\text { br. groba } 10\end{array}$ \\
\hline
\end{tabular}

345. Knjiga mrtvacah obiteljskih grobnica 1902-1919.

\begin{tabular}{|c|c|c|c|c|c|c|c|}
\hline $\begin{array}{l}\text { Red. } \\
\text { broj }\end{array}$ & $\begin{array}{c}\text { Broj } \\
\text { groba }\end{array}$ & $\begin{array}{l}\text { Ime, prezime } \\
\text { i zanimanje }\end{array}$ & $\begin{array}{l}\text { doba, stališ } \\
\text { i rodno } \\
\text { mjesto }\end{array}$ & $\begin{array}{c}\text { mjesto } \\
\text { obitavanja }\end{array}$ & $\begin{array}{c}\text { posljednja } \\
\text { bolest } \\
\text { s koje je umro }\end{array}$ & $\begin{array}{c}\text { dan i godina } \\
\text { kada je } \\
\text { sahranjen }\end{array}$ & Opazka \\
\hline 192 & 64 & $\begin{array}{c}\text { Aurel Schnapp } \\
\text { Kr. ug. dom. satnik }\end{array}$ & $\begin{array}{l}42 \text { god. star } \\
\text { oženjen } \\
\text { Varaždin }\end{array}$ & $\begin{array}{l}\text { Padovčeva } \\
\text { ulica } 8\end{array}$ & $\begin{array}{l}\text { Unutarnje } \\
\text { krvarenje }\end{array}$ & 5. 2. 1915 . & $\begin{array}{c}4 \text { odjel } \\
1 \text { red } \\
1 \text { razred } \\
\text { br. grobnice } 6\end{array}$ \\
\hline 193 & 82 & $\begin{array}{l}\text { Eugen pl. Pust } \\
\text { ces. kr. podpuk. }\end{array}$ & $\begin{array}{l}44 \text { god. star } \\
\text { udovac } \\
\text { Varaždin }\end{array}$ & $\begin{array}{l}\text { Beč, } 20 . \\
12.1918 .\end{array}$ & Tuberkuloza & 29. 12. 1916. & $\begin{array}{c}2 \text { odjel } \\
1 \text { red } \\
1 \text { razred } \\
\text { br. grobnice } 2\end{array}$ \\
\hline 194 & 112 & $\begin{array}{l}\text { Stanislav Magdić } \\
\text { prič. poručnik }\end{array}$ & $\begin{array}{c}21 \text { god. star } \\
\text { neoženjen } \\
\text { Varaždin }\end{array}$ & $\begin{array}{c}\text { Zgb, } \\
\text { bolnica } \\
\text { crvenog } \\
\text { križa }\end{array}$ & Tumor medi(?) & 18. 4. 1918. & $\begin{array}{c}4 \text { odjel } \\
1 \text { red } \\
1 \text { razred } \\
\text { br. grobnice } 7\end{array}$ \\
\hline
\end{tabular}


Vladimir Huzjan: Vojne žrtve Velikog rata i poraća pokopane na varaždinskom groblju (1914.-1919.)

Radovi Zavoda za znanstveni rad HAZU Varaždin; br. 29, 2018., str. 179-222

\begin{tabular}{|c|c|c|c|c|c|c|c|}
\hline $\begin{array}{l}\text { Red. } \\
\text { broj }\end{array}$ & $\begin{array}{l}\text { Broj } \\
\text { groba }\end{array}$ & $\begin{array}{l}\text { Ime, prezime } \\
\text { i zanimanje }\end{array}$ & $\begin{array}{l}\text { doba, stališ } \\
\text { i rodno } \\
\text { mjesto }\end{array}$ & $\begin{array}{c}\text { mjesto } \\
\text { obitavanja }\end{array}$ & $\begin{array}{c}\text { posljednja } \\
\text { bolest } \\
\text { s koje je umro }\end{array}$ & $\begin{array}{l}\text { dan i godina } \\
\text { kada je } \\
\text { sahranjen }\end{array}$ & Opazka \\
\hline 195 & 172 & $\begin{array}{l}\text { Artur pl. Werovski } \\
\text { kr. ug. dom. hus. } \\
\text { podpuk. }\end{array}$ & $\begin{array}{l}55 \text { god. star } \\
\text { oženjen, sud. } \\
\text { Rastavljen } \\
\text { Osijek }\end{array}$ & \begin{tabular}{|c|} 
Zagrebačka \\
22
\end{tabular} & Bolesti srca & 24. 8. 1918. & $\begin{array}{c}1 \text { odjel } \\
1 \text { red } \\
1 \text { razred } \\
\text { br. grobnice } \\
17\end{array}$ \\
\hline 196 & 74 & $\begin{array}{c}\text { Emerich Petrozy } \\
\text { desetnik kod } \\
\text { Verpflegsmagazina } \\
\text { u Zagrebu }\end{array}$ & $\begin{array}{l}23 \text { god. star } \\
\text { neoženjen } \\
\text { Beč }\end{array}$ & $\begin{array}{c}\text { (?) } \\
\text { ekshumiran } \\
\text { i prevežen } \\
\text { ovamo }\end{array}$ & Upala pluća & 30. 5. 1916. & $\begin{array}{c}13 \text { odjel } \\
1 \text { red } \\
1 \text { razred } \\
\text { br. grobnice } 4\end{array}$ \\
\hline 197 & 78 & $\begin{array}{c}\text { Ivan Lehpamer } \\
\text { poruč. } 10 \text { hus. puk. }\end{array}$ & $\begin{array}{l}22 \text { god. star } \\
\text { neoženjen } \\
\text { Varaždin }\end{array}$ & $\begin{array}{l}\text { Srbsko } \\
\text { ratište } \\
\text { Jarebica }\end{array}$ & Pao u bitci & 2. 1. 1917. & $\begin{array}{c}13 \text { odjel } \\
1 \text { red } \\
1 \text { razred } \\
\text { br. grobnice } \\
168\end{array}$ \\
\hline
\end{tabular}

Knjiga mrtvacah občenitih grobova 1902.

\begin{tabular}{|c|c|c|c|c|c|c|c|}
\hline $\begin{array}{l}\text { Red. } \\
\text { broj }\end{array}$ & $\begin{array}{l}\text { Broj } \\
\text { groba }\end{array}$ & $\begin{array}{l}\text { Ime, prezime } \\
\text { i zanimanje }\end{array}$ & $\begin{array}{c}\text { doba, stališ } \\
\text { i rodno mjesto }\end{array}$ & $\begin{array}{c}\text { mjesto } \\
\text { obitavanja }\end{array}$ & $\begin{array}{l}\text { posljednja } \\
\text { bolest } \\
\text { s koje je } \\
\text { umro }\end{array}$ & $\begin{array}{c}\text { dan i } \\
\text { godina kada } \\
\text { je sahranjen }\end{array}$ & Opazka \\
\hline 198 & 495 & $\begin{array}{l}\text { Franjo Banfić } \\
\text { pučki ustaša }\end{array}$ & $\begin{array}{l}\text { oko } 30 \text { god. } \\
\text { Ivanec }\end{array}$ & $\begin{array}{l}\text { vojnička } \\
\text { bolnica }\end{array}$ & Sepsa & 11. 8. 1914. & $\begin{array}{l}16 \text { odjel } \\
1 \text { red } \\
\text { br. groba } \\
1169\end{array}$ \\
\hline 199 & 496 & $\begin{array}{l}\text { Imbro Burdić } \\
\text { c. kr. vojnik }\end{array}$ & $\begin{array}{l}\text { oko } 30 \text { god. } \\
\text { Mihovac } \\
\text { Križevac }\end{array}$ & $\begin{array}{l}\text { vojnička } \\
\text { bolnica }\end{array}$ & Upala pluća & 11. 8. 1914. & $\begin{array}{l}16 \text { odjel } \\
1 \text { red } \\
\text { br. groba } \\
1171\end{array}$ \\
\hline 200 & 382 & $\begin{array}{c}\text { Bartol Friščić Grabar } \\
\text { Res. Corporal des } \\
\text { 10. H. H. Rg. (?) }\end{array}$ & $\begin{array}{c}30 \text { god. star } \\
\text { oženjen Ivanec }\end{array}$ & $\begin{array}{l}\text { Pričuvna } \\
\text { bolnica III. }\end{array}$ & (?) & $\begin{array}{l}22.12 . \\
1914 .\end{array}$ & $\begin{array}{l}16 \text { odjel } \\
4 \text { red } \\
\text { br. groba } \\
1265\end{array}$ \\
\hline
\end{tabular}


Vladimir Huzjan: Vojne žrtve Velikog rata i poraća pokopane na varaždinskom groblju (1914.-1919.)

Radovi Zavoda za znanstveni rad HAZU Varaždin; br. 29, 2018., str. 179-222

\begin{tabular}{|c|c|c|c|c|c|c|c|}
\hline $\begin{array}{l}\text { Red. } \\
\text { broj }\end{array}$ & $\begin{array}{l}\text { Broj } \\
\text { groba }\end{array}$ & $\begin{array}{l}\text { Ime, prezime } \\
\text { i zanimanje }\end{array}$ & $\begin{array}{l}\text { doba, stališ } \\
\text { i rodno mjesto }\end{array}$ & $\begin{array}{c}\text { mjesto } \\
\text { obitavanja }\end{array}$ & $\begin{array}{l}\text { posljednja } \\
\text { bolest } \\
\text { s koje je } \\
\text { umro }\end{array}$ & $\begin{array}{c}\text { dan i } \\
\text { godina kada } \\
\text { je sahranjen }\end{array}$ & Opazka \\
\hline 201 & 383 & $\begin{array}{l}\text { Radoje Pešić } \\
\text { Infant. srbski } \\
\text { ratni zarobljenik }\end{array}$ & $\begin{array}{l}22 \text { god. star } \\
\text { neoženjen } \\
\text { (?) Smederevo } \\
\text { Srbija }\end{array}$ & $\begin{array}{l}\text { Pričuvna } \\
\text { bolnica III. }\end{array}$ & (?) & $\begin{array}{l}23.12 . \\
1914 .\end{array}$ & $\begin{array}{l}16 \text { odjel } \\
4 \text { red } \\
\text { br. groba } \\
1267\end{array}$ \\
\hline 202 & 486 & $\begin{array}{c}\text { Ivan Požgaj } \\
\text { Landsturmphlichtiger } \\
\text { (?) pfleger }\end{array}$ & $\begin{array}{l}23 \text { god.d star } \\
\text { neoženjen } \\
\text { Selnica Zlatar }\end{array}$ & $\begin{array}{l}\text { Pričuvna } \\
\text { bolnica III. }\end{array}$ & Tifus & 17. 5. 1915. & $\begin{array}{l}16 \text { odjel } \\
8 \text { red } \\
\text { br. groba } \\
1372\end{array}$ \\
\hline 203 & 524 & $\begin{array}{l}\text { Jovo Žegrovac } \\
\text { Infanterist d. K. u. } \\
\text { K. Inf. Rg. 79., 2. E. } \\
\text { Korp }\end{array}$ & $\begin{array}{c}35 \text { Jahre alt (?) } \\
\text { Gračac } \\
\text { Hrvatska }\end{array}$ & (?) & (?) & 17. 7. 1915. & $\begin{array}{l}16 \text { odjel } \\
7 \text { red } \\
\text { br. groba } \\
1393\end{array}$ \\
\hline 204 & 530 & $\begin{array}{c}\text { Stjepan Rundić } \\
\text { (?) Hus. Des 10. H. } \\
\text { H. R. }\end{array}$ & $\begin{array}{c}37 \text { Jahre alt } \\
\text { verheiratet } \\
\text { KutjevoPožega } \\
\text { Hrvatska }\end{array}$ & $\begin{array}{c}\text { Pričuvna } \\
\text { bolnica }\end{array}$ & (?) & 27. 7. 1916. & $\begin{array}{l}16 \text { odjel } \\
7 \text { red } \\
\text { br. groba } \\
1399\end{array}$ \\
\hline 205 & 532 & $\begin{array}{c}\text { Gjuro Ceglec } \\
(?) \\
\text { Landsturmpflichtiger } \\
\text { Krankenpfleger }\end{array}$ & $\begin{array}{l}42 \text { god. star } \\
\text { oženjen } \\
\text { Varaždin }\end{array}$ & Reservespital & $\begin{array}{l}\text { Bolesti } \\
\text { trbuha }\end{array}$ & 29. 7. 1915. & $\begin{array}{c}16 \text { odjel } \\
8 \text { red } \\
\text { br. groba } \\
1401\end{array}$ \\
\hline 206 & 539 & $\begin{array}{l}\text { Ivan Sekovanić } \\
\text { (?)soldat d. (?) } \\
\text { magazin Possony }\end{array}$ & $\begin{array}{l}35 \text { god. star } \\
\text { neoženjen } \\
\text { Šćepanje } \\
\text { Novi Marof }\end{array}$ & $\begin{array}{c}\text { Pričuvna } \\
\text { bolnica }\end{array}$ & $\begin{array}{l}\text { Bolesti } \\
\text { bubrega }\end{array}$ & 6. 8. 1915. & $\begin{array}{l}16 \text { odjel } \\
6 \text { red } \\
\text { br. groba } \\
1406\end{array}$ \\
\hline 207 & 571 & $\begin{array}{c}\text { Pavao Ivančić } \\
\text { (?) d. K. u. K. (?) } 13\end{array}$ & $\begin{array}{l}26 \text { god. star } \\
\text { oženjen } \\
\text { Kranjskaves } \\
\text { Klanjec }\end{array}$ & $\begin{array}{l}\text { Pričuvna } \\
\text { bolnica }\end{array}$ & Tuberkuloza & $\begin{array}{l}10.10 . \\
1915 .\end{array}$ & $\begin{array}{l}16 \text { odjel } \\
6 \text { red } \\
\text { br. groba } \\
1427\end{array}$ \\
\hline 208 & 576 & $\begin{array}{l}\text { Franz Pfleger } \\
\text { (?) d. K. u. K. K. Brig. } \\
\text { Sud Ost } 15\end{array}$ & $\begin{array}{c}41 \text { god. star } \\
\text { oženjen } \\
\text { Karlina kamnik } \\
\text { Krain }\end{array}$ & $\begin{array}{l}\text { Pričuvna } \\
\text { bolnica }\end{array}$ & Bolesti srca & $\begin{array}{l}17.10 . \\
1915 .\end{array}$ & $\begin{array}{l}16 \text { odjel } \\
11 \text { red } \\
\text { br. groba } \\
1444\end{array}$ \\
\hline 209 & 570 & $\begin{array}{c}\text { Jakob Matijašić } \\
\text { Landst. (?) H. H. } \\
\text { Rg. } 5\end{array}$ & $\begin{array}{l}18 \text { god. star } \\
\text { neoženjen } \\
\text { Sv. Petar } \\
\text { Ludbreg }\end{array}$ & $\begin{array}{l}\text { Pričuvna } \\
\text { bolnica }\end{array}$ & Upala pluća & $\begin{array}{c}16.11 . \\
1915 .\end{array}$ & $\begin{array}{c}15 \text { odjel } \\
1 \text { red } \\
\text { br. groba } \\
1178\end{array}$ \\
\hline
\end{tabular}


Vladimir Huzjan: Vojne žrtve Velikog rata i poraća pokopane na varaždinskom groblju (1914.-1919.)

Radovi Zavoda za znanstveni rad HAZU Varaždin; br. 29, 2018., str. 179-222

\begin{tabular}{|c|c|c|c|c|c|c|c|}
\hline $\begin{array}{l}\text { Red. } \\
\text { broj }\end{array}$ & $\begin{array}{l}\text { Broj } \\
\text { groba }\end{array}$ & $\begin{array}{l}\text { Ime, prezime } \\
\text { i zanimanje }\end{array}$ & $\begin{array}{l}\text { doba, stališ } \\
\text { i rodno mjesto }\end{array}$ & $\begin{array}{c}\text { mjesto } \\
\text { obitavanja }\end{array}$ & $\begin{array}{l}\text { posljednja } \\
\text { bolest } \\
\text { s koje je } \\
\text { umro }\end{array}$ & $\begin{array}{c}\text { dan i } \\
\text { godina kada } \\
\text { je sahranjen }\end{array}$ & Opazka \\
\hline 210 & 571 & $\begin{array}{c}\text { Stjepan Toth } \\
\text { Landt. Husar K. K. } \\
\text { Hus. Rg. } 10 .\end{array}$ & $\begin{array}{l}18 \text { god. star } \\
\text { neoženjen } \\
\text { Mala (?) } \\
\text { Daruvar }\end{array}$ & $\begin{array}{l}\text { Pričuvna } \\
\text { bolnica }\end{array}$ & Tifus & $\begin{array}{l}17.11 . \\
1915 .\end{array}$ & $\begin{array}{l}15 \text { odjel } \\
1 \text { red } \\
\text { br. groba } \\
1180\end{array}$ \\
\hline 211 & 572 & $\begin{array}{c}\text { Peter Slovik } \\
\text { Zivil arbeiter des (?) } \\
4 / \text { XI }\end{array}$ & $\begin{array}{l}47 \text { god. star } \\
\text { oženjen } \\
\text { (?) Semele } \\
\text { Česka }\end{array}$ & $\begin{array}{l}\text { Pričuvna } \\
\text { bolnica }\end{array}$ & (?) & $\begin{array}{c}20.11 . \\
1915 .\end{array}$ & $\begin{array}{l}15 \text { odjel } \\
1 \text { red } \\
\text { br. groba } \\
1181\end{array}$ \\
\hline 212 & 583 & $\begin{array}{c}\text { Petar Tišanić } \\
\text { Ulan des K. u. K. UI. } \\
\text { R. No. } 5\end{array}$ & $\begin{array}{c}25 \text { god. star } \\
\text { oženjen } \\
\text { Zabok Krapina }\end{array}$ & $\begin{array}{l}\text { Gradska } \\
\text { bolnica }\end{array}$ & $\begin{array}{l}\text { Bolesti } \\
\text { trbuha }\end{array}$ & 4. 12. 1915. & $\begin{array}{l}15 \text { odjel } \\
1 \text { red } \\
\text { br. groba } \\
1191\end{array}$ \\
\hline 213 & 607 & $\begin{array}{c}\text { Wenzel Kulovšek } \\
\text { Husar des K. (?) Hus. } \\
\text { R. No. } 10\end{array}$ & $\begin{array}{l}20 \text { god. star } \\
\text { neoženjen } \\
\text { Daruvar } \\
\text { Kroatien }\end{array}$ & $\begin{array}{l}\text { Pričuvna } \\
\text { bolnica }\end{array}$ & Tifus & $\begin{array}{c}30.12 . \\
1915 .\end{array}$ & $\begin{array}{l}15 \text { odjel } \\
2 \text { red } \\
\text { br. groba } \\
1209\end{array}$ \\
\hline 214 & 155 & $\begin{array}{c}\text { Adam Dragić } \\
\text { Kanoner des s. F. } \\
\text { O. R. } 7\end{array}$ & $\begin{array}{l}51 \text { god. star } \\
\text { oženjen } \\
\text { BI(?) Kroatien }\end{array}$ & $\begin{array}{l}\text { Pričuvna } \\
\text { bolnica }\end{array}$ & Upale & 20. 7. 1916. & $\begin{array}{l}15 \text { odjel } \\
4 \text { red } \\
\text { br. groba } \\
1300\end{array}$ \\
\hline
\end{tabular}


Prilog 3. Popis do sada ne objavljenih osobnih podataka stranih vojnika pokopanih na varaždinskom groblju

345. Knjiga mrtvaca, općeniti grobovi, III (1879) 1903-1918.

\begin{tabular}{|c|c|c|c|c|c|c|c|c|}
\hline $\begin{array}{l}\text { Red. } \\
\text { broj }\end{array}$ & $\begin{array}{l}\text { Broj } \\
\text { groba }\end{array}$ & $\begin{array}{c}\text { Ime, prezime } \mathrm{i} \\
\text { zanimanje }\end{array}$ & $\begin{array}{l}\text { doba, stališ } \\
\text { i rodno } \\
\text { mjesto }\end{array}$ & $\begin{array}{c}\text { mjesto } \\
\text { obitavanja }\end{array}$ & $\begin{array}{l}\text { posljednja } \\
\text { bolest } \\
\text { s koje je } \\
\text { umro }\end{array}$ & $\begin{array}{c}\text { dan i } \\
\text { godina } \\
\text { kada je } \\
\text { sahranjen }\end{array}$ & Opazka & $\begin{array}{l}\text { Napomena } \\
\text { autora }\end{array}$ \\
\hline 1 & 1269 & $\begin{array}{l}\text { Meszaros } \\
\text { Janos } \\
\text { pučki ustaša } \\
\text { 4. (?) topnik } \\
\text { Čakturnye (?) }\end{array}$ & $\begin{array}{l}38 \text { god. } \\
\text { oženjen } \\
\text { Mezótúr } \\
\text { Ugarska }\end{array}$ & $\begin{array}{c}\text { Mezótúr } \\
\text { Ugarska/ } \\
\text { umro u c. i k. } \\
\text { priruč. bolnici } \\
\text { u Varaždinu }\end{array}$ & Upala pluća & $\begin{array}{l}25.2 . \\
1915 .\end{array}$ & $\begin{array}{c}16 \text { tabla } \\
6 \text { red } \\
\text { br. } 1269\end{array}$ & \\
\hline 2 & 163 & $\begin{array}{c}\text { Kuzmin Alexa } \\
\text { pješak }\end{array}$ & $\begin{array}{c}19 \mathrm{~g} \\
\text { neoženjen } \\
\text { (?) Galicija }\end{array}$ & (?) & $\begin{array}{c}\text { Prostrijelna } \\
\text { rana }\end{array}$ & $\begin{array}{c}12.11 . \\
1916 .\end{array}$ & $\begin{array}{l}13 \text { tabla } \\
7 \text { red } \\
\text { br. } 163\end{array}$ & $\begin{array}{l}\text { Počasni } \\
\text { grob }\end{array}$ \\
\hline 3 & 94 & $\begin{array}{c}\text { Antoszko Josef } \\
\text { infanterist }\end{array}$ & $\begin{array}{l}\text { Kamienicz } \\
\text { oženjen } \\
\text { Molstakov }\end{array}$ & Varaždin & Meningitis & $\begin{array}{l}19.8 . \\
1916 .\end{array}$ & $\begin{array}{c}15 \text { tabla } \\
7 \text { red } \\
\text { br. } 94\end{array}$ & $\begin{array}{l}\text { Počasni } \\
\text { grob }\end{array}$ \\
\hline 4 & 111 & $\begin{array}{c}\text { Selich Johann } \\
\text { ratnik, } \\
\text { tvornički } \\
\text { radnik }\end{array}$ & $\begin{array}{c}39 \text { god. } \\
\text { oženjen } \\
\text { Sonoleitz(?) }\end{array}$ & Varaždin & (?) & 5. 3. 1916 . & $\begin{array}{l}13 \text { tabla } \\
3 \text { red } \\
\text { br. } 111\end{array}$ & $\begin{array}{c}\text { Počasni } \\
\text { grob. Isti } \\
\text { upis u: } \\
\text { 345. Knjiga } \\
\text { mrtvacah } \\
\text { obiteljskih } \\
\text { grobnica } \\
\text { 1902.- } \\
\text { 1919., red. } \\
\text { br. } 440 \\
\end{array}$ \\
\hline 5 & 1261 & $\begin{array}{l}\text { Frei Janos } \\
\text { vojnik } \\
\text { poljodjelac }\end{array}$ & $\begin{array}{l}18 \text { god. } \\
\text { (?) }\end{array}$ & Varaždin & Upala pluća & $\begin{array}{c}26.11 . \\
1916 .\end{array}$ & $\begin{array}{l}15 \text { tabla } \\
3 \text { red } \\
\text { br. } 1261\end{array}$ & \begin{tabular}{|c|} 
Vojnički \\
grob. Isti \\
upis u: \\
Knjiga \\
mrtvacah \\
občenitih \\
grobova \\
1902., \\
red. br. 634 \\
\end{tabular} \\
\hline 6 & 324 & $\begin{array}{c}\text { Emerich } \\
\text { Goricsanecz } \\
\text { vojnik }\end{array}$ & $\begin{array}{l}21 \text { god. } \\
\text { neoženjen } \\
\text { (?) Terlak }\end{array}$ & $\begin{array}{c}\text { (?) Terlak } \\
\text { Zala megye }\end{array}$ & $\begin{array}{c}\text { Upala } \\
\text { potrbušnice }\end{array}$ & $\begin{array}{l}23.7 . \\
1918 .\end{array}$ & $\begin{array}{l}13 \text { tabla } \\
1 \text { red } \\
\text { br. } 324\end{array}$ & $\begin{array}{l}\text { Počasni } \\
\text { grob }\end{array}$ \\
\hline
\end{tabular}


Vladimir Huzjan: Vojne žrtve Velikog rata i poraća pokopane na varaždinskom groblju (1914.-1919.)

Radovi Zavoda za znanstveni rad HAZU Varaždin; br. 29, 2018., str. 179-222

\begin{tabular}{|c|c|c|c|c|c|c|c|c|}
\hline $\begin{array}{l}\text { Red. } \\
\text { broj }\end{array}$ & $\begin{array}{l}\text { Broj } \\
\text { groba }\end{array}$ & $\begin{array}{l}\text { Ime, prezime i } \\
\text { zanimanje }\end{array}$ & $\begin{array}{l}\text { doba, stališ } \\
\text { i rodno } \\
\text { mjesto }\end{array}$ & $\begin{array}{c}\text { mjesto } \\
\text { obitavanja }\end{array}$ & $\begin{array}{c}\text { posljednja } \\
\text { bolest } \\
\text { s koje je } \\
\text { umro }\end{array}$ & $\begin{array}{c}\text { dan i } \\
\text { godina } \\
\text { kada je } \\
\text { sahranjen }\end{array}$ & Opazka & $\begin{array}{c}\text { Napomena } \\
\text { autora }\end{array}$ \\
\hline 7 & 323 & $\begin{array}{c}\text { Dionisius } \\
\text { Krzyczkowsky } \\
\text { vojnik }\end{array}$ & $\begin{array}{l}21 \text { god. } \\
\text { Kolomea } \\
\text { Galicija }\end{array}$ & $\begin{array}{l}\text { Kolomea } \\
\text { Galicija }\end{array}$ & Upala pluća & $\begin{array}{l}23.7 . \\
1918 .\end{array}$ & $\begin{array}{c}13 \text { tabla } \\
1 \text { red } \\
\text { br. } 323\end{array}$ & $\begin{array}{c}\text { Počasni } \\
\text { grob. Isti } \\
\text { upis u: } \\
\text { 345. Knjiga } \\
\text { mrtvacah } \\
\text { obiteljskih } \\
\text { grobnica } \\
\text { 1902.- } \\
\text { 1919., red. } \\
\text { br. } 390 \\
\end{array}$ \\
\hline 8 & 325 & $\begin{array}{l}\text { Mato } \\
\text { Lovrenčić } \\
\text { vojnik }\end{array}$ & $\begin{array}{l}45 \text { god. } \\
\text { oženjen } \\
\text { (?) Perlak } \\
\text { Ungarn }\end{array}$ & $\begin{array}{c}\text { (?) Terlak } \\
\text { Zala megye }\end{array}$ & Diabetes & $\begin{array}{l}29.7 . \\
1918 .\end{array}$ & $\begin{array}{l}13 \text { tabla } \\
7 \text { red } \\
\text { br. } 325\end{array}$ & $\begin{array}{l}\text { Počasni } \\
\text { grob }\end{array}$ \\
\hline 9 & 381 & $\begin{array}{c}\text { Gyorgy Horvat } \\
\text { vojnik }\end{array}$ & $\begin{array}{c}46 \text { god. neož. } \\
\text { Visiszent } \\
\text { Gyorgy }\end{array}$ & $\begin{array}{c}\text { Visiszent } \\
\text { Gyorgy } \\
\text { Csaktornya } \\
\text { Zala Ugarska }\end{array}$ & Upala pluća & $\begin{array}{c}22.10 . \\
1918 .\end{array}$ & $\begin{array}{l}13 \text { tabla } \\
7 \text { red } \\
\text { br. } 381\end{array}$ & $\begin{array}{l}\text { Počasni } \\
\text { grob }\end{array}$ \\
\hline 10 & 345 & $\begin{array}{l}\text { Michael } \\
\text { Gudlui } \\
\text { vojnik }\end{array}$ & $\begin{array}{l}42 \text { god. } \\
\text { oženjen } \\
\text { Mura(?) }\end{array}$ & $\begin{array}{l}\text { Mura(?) } \\
\text { Ungarn }\end{array}$ & $\begin{array}{c}\text { Gangrena } \\
(?)\end{array}$ & $\begin{array}{l}7.10 . \\
1918 .\end{array}$ & $\begin{array}{c}13 \text { tabla } \\
1 \text { red } \\
\text { br. } 345\end{array}$ & $\begin{array}{l}\text { Počasni } \\
\text { grob }\end{array}$ \\
\hline 11 & 331 & $\begin{array}{l}\text { Michael } \\
\text { Hadelau } \\
\text { vojnik }\end{array}$ & $\begin{array}{l}33 \text { god. } \\
\text { oženjen } \\
\text { Mura(?) }\end{array}$ & $\begin{array}{c}\text { Mura(?) } \\
\text { Csaktornya } \\
\text { Zala }\end{array}$ & (?) & $\begin{array}{l}18.8 . \\
1918 .\end{array}$ & $\begin{array}{c}13 \text { tabla } \\
7 \text { red } \\
\text { br. } 331\end{array}$ & $\begin{array}{l}\text { Počasni } \\
\text { grob }\end{array}$ \\
\hline
\end{tabular}

345. Knjiga mrtvacah obiteljskih grobnica 1902.-1919.

\begin{tabular}{|c|c|c|c|c|c|c|c|}
\hline $\begin{array}{l}\text { Red. } \\
\text { broj }\end{array}$ & $\begin{array}{l}\text { Broj } \\
\text { groba }\end{array}$ & $\begin{array}{l}\text { Ime, prezime } \\
\text { i zanimanje }\end{array}$ & $\begin{array}{c}\text { doba, stališ } \\
\text { i rodno } \\
\text { mjesto }\end{array}$ & $\begin{array}{c}\text { mjesto } \\
\text { obitavanja }\end{array}$ & $\begin{array}{l}\text { posljednja } \\
\text { bolest } \\
\text { s koje je } \\
\text { umro }\end{array}$ & $\begin{array}{c}\text { dan i godina } \\
\text { kada je } \\
\text { sahranjen }\end{array}$ & Opazka \\
\hline 12 & 143 & $\begin{array}{c}\text { Oskar } \\
\text { Wegscheider } \\
\text { c. i kr. topnički } \\
\text { kapetan }\end{array}$ & $\begin{array}{l}46 \text { god. star } \\
\text { oženjen } \\
\text { Schaerding } \\
\text { u Gornjoj } \\
\text { Austriji }\end{array}$ & $\begin{array}{c}\text { Kukuljevićeva } \\
\text { ul. } 4\end{array}$ & Ustrelio se & 14.9. 1914. & $\begin{array}{c}\text { Ekshumiran i } \\
\text { prevežen } \\
\text { u Gradac na } \\
\text { temelju } \\
\text { odluke gr. redarstva } \\
\text { br. } 4994 / 914 .\end{array}$ \\
\hline
\end{tabular}


Vladimir Huzjan: Vojne žrtve Velikog rata i poraća pokopane na varaždinskom groblju (1914.-1919.)

Radovi Zavoda za znanstveni rad HAZU Varaždin; br. 29, 2018., str. 179-222

\begin{tabular}{|c|c|c|c|c|c|c|c|}
\hline $\begin{array}{l}\text { Red. } \\
\text { broj }\end{array}$ & $\begin{array}{l}\text { Broj } \\
\text { groba }\end{array}$ & $\begin{array}{l}\text { Ime, prezime } \\
\text { i zanimanje }\end{array}$ & $\begin{array}{l}\text { doba, stališ } \\
\text { i rodno } \\
\text { mjesto }\end{array}$ & $\begin{array}{c}\text { mjesto } \\
\text { obitavanja }\end{array}$ & $\begin{array}{l}\text { posljednja } \\
\text { bolest } \\
\text { s koje je } \\
\text { umro }\end{array}$ & $\begin{array}{l}\text { dan i godina } \\
\text { kada je } \\
\text { sahranjen }\end{array}$ & Opazka \\
\hline 13 & 333 & $\begin{array}{l}\text { Nestor Bizurii } \\
\text { (?) ustaški } \\
\text { vodnik } \\
\text { dom. puk. } 26 . \\
2 \text { satnije }\end{array}$ & $\begin{array}{l}37 \text { god. star } \\
\text { oženjen } \\
\text { Weradin kot. } \\
\text { Izig }\end{array}$ & (?) & Tifus & 3. 2. 1915 . & $\begin{array}{c}13 \text { odjel } \\
9 \text { red } \\
\text { br. groba } 26\end{array}$ \\
\hline 14 & 397 & $\begin{array}{l}\text { Alois Jelušić } \\
\text { Inf. d. K. u. K. } \\
\text { Inf. reg. } 5\end{array}$ & $\begin{array}{l}22 \text { g. star } \\
\text { neoženjen } \\
\text { Plesgvics } \\
\text { (?)stenland }\end{array}$ & (?) & $\begin{array}{l}\text { Prostrijelne } \\
\text { rane }\end{array}$ & 7. 8. 1915. & $\begin{array}{c}13 \text { odjel } \\
2 \text { razred } \\
8 \text { red } \\
\text { br. groba } 61\end{array}$ \\
\hline 15 & 177 & $\begin{array}{l}\text { Franz Marušar } \\
\text { Inf. K. K. div. } 4 \text {, } \\
12 \text { korp. }\end{array}$ & $\begin{array}{l}42 \text { god. star } \\
\text { oženjen rkt. } \\
\text { Brezovica } \\
\text { Krain }\end{array}$ & $\begin{array}{l}\text { Pričuvna } \\
\text { bolnica }\end{array}$ & (?) & 26. 10. 1916. & $\begin{array}{c}13 \text { odjel } \\
8 \text { red } \\
\text { br. groba } 158\end{array}$ \\
\hline 16 & 190 & $\begin{array}{l}\text { Wasyl Houzer } \\
\text { Inf. K. K. hus } \\
23,1 . \text { korp }\end{array}$ & $\begin{array}{l}23 \text { god. star } \\
\text { neoženjen } \\
\text { (?) Galizia }\end{array}$ & (?) & (?) & 25. 1. 1917. & $\begin{array}{c}13 \text { odjel } \\
2 \text { razred } \\
\text { br. groba } 171\end{array}$ \\
\hline 17 & 191 & $\begin{array}{l}\text { Bolto Trpolko } \\
\text { (?) div } 13\end{array}$ & $\begin{array}{l}46 \text { god. star } \\
\text { oženjen } \\
\text { Prljina } \\
\text { (?) }\end{array}$ & (?) & (?) & 29. 1. 1917. & $\begin{array}{c}13 \text { odjel } \\
2 \text { razred } \\
\text { br. groba } 172\end{array}$ \\
\hline 18 & 195 & $\begin{array}{l}\text { Sava Gabovo } \\
\text { Inf. D. K. u. K. } \\
\text { hus. 7, } 3 \text { korp. }\end{array}$ & $\begin{array}{l}23 \text { god. star } \\
\text { oženjen } \\
\text { (?) Nagy(?) }\end{array}$ & $\begin{array}{l}\text { Pričuvna } \\
\text { bolnica III. }\end{array}$ & Tuberkuloza & 9. 2. 1917 . & $\begin{array}{c}13 \text { odjel } \\
2 \text { razred } \\
\text { br. groba } 176\end{array}$ \\
\hline 19 & 197 & $\begin{array}{l}\text { Simon Kuloš } \\
\text { (?) I. R. } 25\end{array}$ & $\begin{array}{l}50 \text { god. star } \\
\text { (?) oženjen (?) }\end{array}$ & $\begin{array}{l}\text { Pričuvna } \\
\text { bolnica III. }\end{array}$ & Meningitis & 11. 2. 1917. & $\begin{array}{c}13 \text { odjel } \\
2 \text { razred } \\
\text { br. groba } 178\end{array}$ \\
\hline
\end{tabular}


Knjiga mrtvacah občenitih grobova 1902.

\begin{tabular}{|c|c|c|c|c|c|c|c|}
\hline $\begin{array}{l}\text { Red. } \\
\text { broj }\end{array}$ & $\begin{array}{l}\text { Broj } \\
\text { groba }\end{array}$ & $\begin{array}{l}\text { Ime, prezime } \\
\text { i zanimanje }\end{array}$ & $\begin{array}{l}\text { doba, stališ } \\
\text { i rodno mjesto }\end{array}$ & $\begin{array}{c}\text { mjesto } \\
\text { obitavanja }\end{array}$ & $\begin{array}{c}\text { posljednja } \\
\text { bolest } \\
\text { s koje je umro }\end{array}$ & $\begin{array}{c}\text { dan i } \\
\text { godina kada } \\
\text { je sahranjen }\end{array}$ & Opazka \\
\hline 20 & 378 & $\begin{array}{l}\text { Antun Riedl } \\
\text { Inf. (?) } 73\end{array}$ & $\begin{array}{l}23 \text { god. star } \\
\text { neoženjen } \\
\text { (?) Bohmen }\end{array}$ & $\begin{array}{l}\text { Pričuvna } \\
\text { bolnica III. }\end{array}$ & Tifus & $\begin{array}{c}14.10 . \\
1914 .\end{array}$ & $\begin{array}{l}16 \text { odjel } \\
3 \text { red } \\
\text { br. groba } \\
1239\end{array}$ \\
\hline 21 & 453 & $\begin{array}{l}\text { Petrošek Skalo } \\
\text { vojnički vozar }\end{array}$ & $\begin{array}{l}51 \text { god. star } \\
\text { oženjen } \\
\text { Maine Butka } \\
\text { Galicija }\end{array}$ & Četna bolnica & (?) & 10. 3. 1915. & $\begin{array}{l}16 \text { odjel } \\
5 \text { red } \\
\text { br. groba } \\
1345\end{array}$ \\
\hline 22 & 471 & $\begin{array}{c}\text { Rudolf Polak } \\
\text { (?) d. K. K. (?) N. } \\
5 \text { (?) }\end{array}$ & $\begin{array}{l}21 \text { god. star } \\
\text { neoženjen } \\
\text { Jablanca (?) }\end{array}$ & $\begin{array}{l}\text { Pričuvna } \\
\text { bolnica III. }\end{array}$ & Upala pluća & 28. 4. 1915. & $\begin{array}{l}16 \text { odjel } \\
8 \text { red } \\
\text { br. groba } \\
1362\end{array}$ \\
\hline 23 & 577 & $\begin{array}{l}\text { Mihael Nalepa } \\
\text { Zivil kutscher } \\
\text { d. K. u. K. (?) } \\
\text { Feldhaibdivision } \\
\qquad 22\end{array}$ & $\begin{array}{l}23 \text { Jahre alt } \\
\text { Bedig } \\
\text { (?) Gradek } \\
\text { Galizien }\end{array}$ & $\begin{array}{l}\text { Pričuvna } \\
\text { bolnica }\end{array}$ & Tuberkuloza & 18. 8. 1915. & $\begin{array}{c}16 \text { odjel } \\
11 \text { red } \\
\text { br. groba } \\
1446\end{array}$ \\
\hline 24 & 563 & $\begin{array}{c}\text { Karl Hirscher } \\
\text { Zivilarbeiter d. K. } \\
\text { u. K. Feldspital } \\
\text { 3/10 }\end{array}$ & $\begin{array}{l}51 \text { god. star } \\
\text { oženjen } \\
\text { Nimes Bohm } \\
\text { Leips }\end{array}$ & $\begin{array}{l}\text { Pričuvna } \\
\text { bolnica }\end{array}$ & Bolesti srca & $\begin{array}{l}11.10 . \\
1915 .\end{array}$ & $\begin{array}{c}16 \text { odjel } \\
11 \text { red } \\
\text { br. groba } \\
1454\end{array}$ \\
\hline
\end{tabular}

